Notre Dame Law School

NDLScholarship

Natural Law Forum

$1-1-1965$

\title{
The Importance of Being: Some Reflections on Existentialism in Relation to Law
}

Anthony R. Blackshield

Follow this and additional works at: http://scholarship.law.nd.edu/nd_naturallaw_forum

Part of the Law Commons

\section{Recommended Citation}

Blackshield, Anthony R., "The Importance of Being: Some Reflections on Existentialism in Relation to Law" (1965). Natural Law Forum. Paper 105.

http://scholarship.law.nd.edu/nd_naturallaw_forum/105

This Article is brought to you for free and open access by NDLScholarship. It has been accepted for inclusion in Natural Law Forum by an authorized administrator of NDLScholarship. For more information, please contact lawdr@nd.edu. 
The Association between law and philosophy is sanctioned by more than two thousand years of fertile reciprocal influence. The contents and techniques of the law, even in its most everyday "practical" aspects, have been shaped again and again by philosophy, both through deliberate resort on the part of lawyers and through the unplanned but inescapable influence of the often inarticulate philosophical outlooks which they willy-nilly hold. ${ }^{1}$ The very fact that this sort of philosophical influence has not always been desirable should urge us to alertness for its new or renewed potentialities: both for desirable contributions, so that we may know what uses of philosophy we should be making; and for undesirable ones, so that we may know what unconscious influences we should be on our guard against. Even an inquiry which yielded the conclusion that a particular body of philosophy contained no possible contributions to the law whatsoever might still be useful as clearing the ground and helping to direct our concern in more suitable directions.

Nor, of course, do contributions to the law itself exhaust the matter. When a lawyer seeks to understand the nature of the law in which he works

* This article was originally planned as a collaborative venture to be undertaken jointly by myself and Mr. J. S. Goldstein, of the New South Wales Bar, an early draft being presented under our joint authorship to a meeting of the Australian Society of Legal Philosophy on August 8, 1964. My present treatment remains indebted to Mr. Goldstein for an occasional turn of phrase and many stimulating ideas. I am also indebted, both for encouragement and suggestions and for stimulating challenges and criticisms, to other members of the above Society and of the Department of Jurisprudence and International Law in the University of Sydney, in particular to Dr. Ilmar Tammelo, Reader in that Department, and Miss Lyndel V. Prott, now of the Free University of Brussels; and to my friends at the University of Virginia Law School, in whose congenial surroundings most of the final writing was done.

In attempting here to discover what attitudes and analyses existentialism might bring to problems of legal philosophy, I have usually had to proceed by trying to project what an existentialist might say if he were ever to address his mind to such problems. Such projected attitudes and analyśes are of course not necessarily my own. But they will often in fact lie fairly close to what I myself would say, though in a statement offered (as it were) in my own proper person, I would regard any existentialist support as at most of only collateral and incidental interest. Some of the ideas which I shall here offer as "existentialist" $I$ have in fact made a much more tentative and unsatisfying endeavor to work out on my own behalf in an article published in Italian and cited infra note 89.

1 See, e.g., on nineteenth century American law Roscoe Pound, The Role of the Will in Law, 68 Harvard Law Review 1 (1954); Julius Stone, Human Law and Human Justice 89.99 (1965). And of. the latter work generally. 
and of the fundamental notions it employs, he inevitably turns to philosophy for assistance; ${ }^{2}$ and this kind of philosophic influence, even when of no assistance to the law, may be of the greatest assistance to the lawyer in his struggle with the human and ethical problems of a lawyer's life. Philosophers, for their part, must find in the law part of the subject matter for their work, and may also find in it fruitful paradigmata, and useful symbols or ciphers, to be employed in philosophizing. ${ }^{3}$ This borrowing of symbols or ciphers the use of another discipline's intellectual constructs as metaphors for the expression of what one's own discipline seeks to say - may also be a main channel of assistance from philosophy to law; especially when the philosophy is one, such as existentialism, which abounds in metaphors and symbols as its staple means of expression.

For all these reasons it ought to be taken for granted that whenever. a new and influential philosophy arises, lawyers should struggle to understand it. If any philosophy has been widely regarded as a new philosophy of our century, it is existentialism; $;^{4}$ and though its claim to novelty is open to question, ${ }^{\mathbf{5}}$ it is at least a distinctively contemporary field of philosophic endeavor, which on that ground alone is worthy of notice by the contemporary lawyer. I have even heard it argued that this philosophy, explicitly put forward as a "philosophy of life," is a particularly appropriate one for lawyers, since their field of activity is so largely that of "life."

But precisely in the case of existentialism, we must tread more carefully than this; and that for two reasons. First, while it is true that this is offered as a philosophy of life, it is also a philosophy of individual life, in which the structure and the meaning of individual human existence are probed in a highly subjective way. And it may be said that even if the subjective illuminations and evaluations which result are of the deepest significance for the subjective individual human being in his personal orientation to the

2 See Julius Stone, Legal System ind Lawyers' Reasonings 162-166 (1964).

${ }^{3}$ See generally Ilmar Tammelo, On the Lawyer's Search for Contact with the Philosopher, 13 Journal of Leoal Education 441, at 441-443 (1961).

4 Linguistic philosophy can claim to be newly fashionable, but hardly to be new. See my study, The Game They Dare Not Bite: Or, What's Wrong with Linguistic Analysis, 3 JaIPUR Law Journal 44 (1963).

S In the last analysis the claim probably can be sustained in the sense that while the existentialist themes are not new, the enterprise of philosophizing about them is; and that this enterprise is in part a reaction to the distinctively modern trends to homogenization and collectivization of man. Both these matters will be discussed below. On the other hand, both Martin Heidegger and Karl Jaspers constantly stress the historicity of thought and the need for continuity in thought; and their own homage to thinkers such as Kant, Duns Scotus, Socrates, Plato, and the pre-Socratics (not to mention Kierkegaard and Nietzsche) is a model of recognition and acknowledgment of indebtedness to one's predecessors, which in this respect at least other contemporary intellectual movements would do well to emulate. See my article cited supra note 4, at 83-86. Jean-Paul Sartre's insouciance even towards Heidegger, his master and model, is a notable exception. 
problems of his life, they can be of no significance for law, which is concerned with the objective actions and material needs of these subjective human individuals in their relations with one another. Whether our legal discussions seek to describe what legal phenomena are like, or to prescribe a content for the "justice" to which they should be dedicated, they must have an objective, relational, generalized orientation in which existentialist individualism is simply out of place. ${ }^{6}$ In various guises, this problem will recur throughout the present study, in particular in the form of a conflict between the existentialist implication that justice must be found subjectively for each individual, and the legal implication that justice must be found objectively from one individual to another. It is perhaps the deepest problem which any attempt to apply existentialism to law has to face. But the problem is not peculiar to existentialism; it is in fact one of the oldest problems of legal philosophy. To discuss such an ancient problem in a new and provocative context may well throw new light, at least upon the problem itself.

The second reason is less disturbing in its implications for our attempt to expound existentialism, but very much more disturbing in its implications for the human situation generally. This is that existentialism sometimes provokes among philosophers, and among other thinkers, an attitude which is the very opposite of philosophy: the attitude of missophia, or more crudely "antiknowledge." Perhaps understandably, this radical intolerance towards existentialism seems mainly to be found in British countries. In continental philosophy, existentialism is of course by far the most pervasive contemporary influence; it is almost the matrix of modern continental philosophic thought, in a far more basic and radical sense than, for instance, linguistic philosophy in England. Even for those contemporary continental philosophers who are not existentialists (and of course there are many), existentialism is part of the philosophic air they breathe. There can be no adequate understanding of modern continental philosophy without a thorough understanding of existentialism. This extends to the work of continental legal philosophers as well; and in this respect as in many others, the important legal-philosophical work now being done in Latin-American countries shares the continental character. In the United States, too, existentialism has found a warm and enthusiastic welcome from many thinkers, though of course it must jostle for place with all the other philosophical movements that also find a foothold in the loose-knit, generous, and hospitable American philosophical climate. But in England, serious attention to existentialism is only now beginning to emerge as a respectable philosophical concern: until quite recently,

See infra pp. 114-21; 139. And cf. Lon L. Fuller, The Moraltty of Law ch. 2 (1964). 
the only philosophers to take this branch of philosophy seriously were, significantly enough, those like Iris Murdoch who combine a philosophical with a literary career. Significantly, too, the present beginnings of an English thaw towards existentialism owe much to the realization that there are deep existentialist leanings in the basic thought of Ludwig Wittgenstein. ${ }^{7}$ It must still be said that for many English philosophers, and for most philosophers in other British countries, "existentialism" remains a dirty word. This reaction too often arises, not merely from a nonunderstanding of the existentialist concerns, but from an unwillingness to try to understand them.

I do not, of course, mean to deny tenability to the philosophical judgment that existentialism is vague, subjective, and unfocused, that it is the stuff of daydreams masquerading as philosophy. Nor am I here adopting as my own the converse judgment that existentialism is "true," that it successfully translates into terms of philosophical illumination the deep comitragedy of human existence. To engage in a serious study of existentialism is probably to find oneself hovering inescapably between these two judgments, tending now towards one, now towards the other. If, however, the former, negative view is not a judgment at all, but a prejudice, and a fortiori if it is used, whether reached by judgment or by prejudice, as a basis for saying that the discussion of existentialism is an undesirable or improper activity, then in either case a position is reached which seems to call for emphatic repudiation as narrow-minded, illiberal, and unscholarly. Even if the widespread influence of existentialism in non-British countries were not sufficient warrant for embarking on the present study, I would tend to find such warrant simply in the fact that these last two positions are, regrettably, both encountered in British academic circles, sometimes in unexpected quarters.

Not the least regrettable result of the tendencies just mentioned is that they tend to press the expounder of existentialism into the false position of appearing to espouse what he expounds. I ought therefore to add explicitly that my purpose is more modest and less hazardous than polemical advocacy. It is, first, to offer some general remarks about the nature of existentialism as a philosophic movement, and to introduce the novice to some main concepts, structures, and problems of existentialist philosophies. My major purpose will then be to point briefly on this basis to some of the issues which such philosophies might raise for jurisprudence - in relation respectively to analytical jurisprudence, sociological jurisprudence, and the theory of justice. Nothing more is intended. In face of the above hostilities I cannot help wishing that my coverage might have been deeper; that the contents and

${ }^{7}$ See Erich Heller, Ludwig Wittgenstein: Unphilosophical Notes, 13 Encounter (No. 3) 40 (1959); and Blackshield, article cited supra note 4, at 49-50. 
anxieties of existentialism might have been conveyed more adequately; and that I might have done more of grappling with the issues I shall mention, and less of merely skimming over their often deceptively shallow surface levels. To plunge so deeply at this stage, however, would be to beg the very question that I here want to pose. This is whether the potential contributions of existentialism to legal thought are such as to justify a study of the proportions that deeper penetration would require.

I do not intend to suggest, either, that in thus seeking to explore existentialism's possible juristic implications I am breaking new jurisprudential ground. Some jurists (for instance Werner Maihofer ${ }^{8}$ ) have developed novel jurisprudential theories building squarely on existentialist assumptions; others, such as Georg Cohn ${ }^{9}$ and Erich Fechner, ${ }^{10}$ have recast their more traditional legal theories in existentialist terminology. Still others, such as Ilmar Tammelo ${ }^{11}$ and his distinguished pupil, Arthur Kaufmann, ${ }^{12}$ while refraining from aligning themselves with existentialism, have been ready to make sympathetic use of its insights and analogies, when the occasion arises at incidental points in their work. But there does not seem to have been any systematic attempt to bring out the jurisprudential implications of the main existentialist philosophies themselves. Here, too, awareness of the necessity for such an attempt has begun to creep into the literature; but here the attitude tends to be, in effect, "Yes, it is important to see how existentialism affects law; but it will be an enormously difficult job, and I prefer to leave it to someone else."13 While this, in effect, must be my attitude also, I hope to indicate the more salient points which the main existentialist writers have made, and the kinds of significance these points may have for law.

${ }^{8}$ See especially his Die Natur der Sache, 44 Archiv für Rechts- und Sozinlphilosophie 145 (1958), and his Vom Sinn menschligher Ordnung (1956). And see Ilmar Tammelo, The Nature of Facts as a Juristic Tópos, in Australian Studies in Legal Phizosophy (ed. by Ilmar Tammelo, A. R. Blackshield, and Enid Campbell, and published as Beiheft No. 39 of Das Archiv für Rechts- und Sozialphilosoprie) 236, esp. at $244 \mathrm{ff}$. (1963) ; and Julius Stone, "The Nature of Things" on the Way to Positivism? 50 Archrv FüR Rechts- UND Sozialphilosophie 145 (1964).

- Existentialismus und Rechtswissenschaft (1957).

10 See, e.g., his Rechtsphimosophie: Soziologie und Metaphysik des Rechts (1965), and his Naturrecht und Existenzphilosophie, 41 ARGHIv für Rechts- Und Sozialphilosophie 305 (1955). Among other contemporary German natural lawyers to be influenced by existentialism see especially Johannes MESSNER, DAs NaturRecht (2nd ed., 1958) and Carl Emge, Einführuno in die Reghtsphilosophie (1955).

11 See among many articles illustrating this his Justice and Doubt, 9 OSTrRreichische ZEITSGHRIFT FüR ÖFFENTLICHES RECHT 308 (1959).

12 See especially his NaturRecht UND Geschichterchkeit (1957). And see his article, The Ontological Structure of Law, 8 Natural LAw Forum 79 (1963), subject, however, to some condensation of ideas in translation. There is a full account in STONE, op. cit. supra note 1, at 204-207. And see infra notes 57, 65.

${ }^{13}$ See, e.g., the recent treatment in W. Friedman N, Legal Theory 151-152 (4th ed., 1960). And cf. Stone, op. cit. supra note 1, at 202-204, who while he perhaps carries the matter somewhat further than Friedmann, admits at 204 that "No doubt much wisdom 


\section{Existentialism}

A. Exponents. - Whom are we to select as the main existentialist writers? The two immediate founding fathers of the movement in this century are the German philosophers Karl Jaspers (b. 1883) and Martin Heidegger (b. 1889). Unquestionably each of these must be taken into account. But the French writer Jean-Paul Sartre (b. 1905), though a much younger man and a pupil of Heidegger's, must be given equal prominence; for he has developed (if not twisted) existentialism into a peculiar personal form, which by an odd quirk of intellectual history has become so widely known that for most people Sartre is now the existentialist. This mistaken identification is probably a main reason both for the popular appeal of existentialism and for the hostilities to it already referred to.

It is therefore the more important to stress at the outset that Sartrian existentialism is a unique and highly personal product, which many other existentialists would emphatically disavow. Since it must also be stressed that this can equally be said of the Jaspers or the Heidegger "product," we are immediately confronted (even if we confine attention to these three pivotal thinkers) with the question whether there is any point at all in inquiring what "existentialism" or "the existentialists" might have to say to lawyers. For such an inquiry assumes that "the existentialists" would speak to lawyers (if they did so at all) with one voice; whereas the fact is that they do not so speak (when they speak at all) even to each other. The Existenzphilosophie of Jaspers and the existentialisme of Sartre are a world apart. I believe, however, that we should be neither surprised at, nor excessively disheartened by, the radical disagreements of existentialists inter se. For I shall suggest in this article that the structural framework of their philosophy is such that it positively demands to be filled with a content drawn from the personal idiosyncrasies and outlook of each thinker who employs it. This implies that, at least as to the structural framework of this philosophy itself, there is among

relevant to the search for good law could be distilled from such earnest thinkers, so keenly observant of their world and sensitive to the great ethical systems. But it has defied the present efforts to provide the flavour even in paraphrase. The distillation would be a labour of Sisyphus. ..." But on the more limited plane of response to Maihofer's efforts cited supra note 8 , see Stone's article also there cited. And see infra note 57.

The position is of course somewhat different on the Continent, especially in Germany. Yet even there "existentialist jurisprudence" is largely confined to the kind of piecemeal (though often extensive) borrowings already referred to. The major exception to date is probably UlRich Hommes, Die EXIstenzerhelluno UNd DAS Recht (1962), which came to my attention only after this article had been written. The substantial limitation of this work to Jaspers' philosophy, as I shall suggest at the end of this article, is probably jurisprudentially wise; and within these limits, the book comes very close to the kind of systematic search for insights here envisaged. 
its exponents sufficient common ground and common approach to enable us to regard them all as belonging to the same philosophical movement. ${ }^{14}$

An exhaustive treatment of modern existentialism would need to consider many other writers outside this central triumvirate. Men like Gabriel Marcel $^{15}$ and the late Louis Lavelle ${ }^{16}$ have been only slightly (if at all) inferior in importance and influence to the triumvirate itself. More definitely "secondary" existentialists are the existentialist theologians such as the late Martin Buber, ${ }^{17}$ Paul Tillich and Rudolf Bultmann, ${ }^{18}$ and (more doubtfully) Etienne Gilson and Jacques Maritain; ${ }^{19}$ but these too have had important things to

14 See Ilmar Tammelo, Comment on an Existentialist Critigue of Psychoanalysis, 15 Meanjin 61, at 62 (1956).

15 Marcel's main works here relevant include Journal Métaphysique 1914-1923 (1927); Etre et Avoir (1935); Homo Viator (1945); Positions et Approches ConCRètes dU Mystère Ontoloorque (1949); Le MYStère de L'Etre (2 vols., 1951); Les Hommes CONTRE L'Humain (1951).

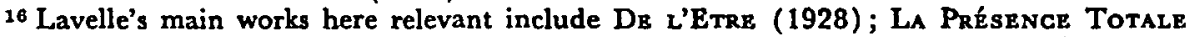
(1934); Le Moi et son Destin (1936); La Dialectique de l'Eternel Présent (3 vols., 1927-1945); Du TEMPS ET DE L'ETERNITÉ (1945); INTROduction $\lambda$ L'ONTOLOOIE (1947); Les Puissances du Mor (1948); De l'Ame Humaine (1951); Tratte des Valeurs 2 vols., 1951-1955). On the results of Lavelle's ideas for moral philosophy, see Rene Le Senne, Louis Lavelle, 7 Grornale di Metafisica 405 (1952); and for legal philosophy, Ilmar Tammelo, On the Space and Limits of Legal Experience, 11 Journal or Legal Education 171 (1958).

Almost every existentialist philosophy is subject to disputes (by other existentialists, by commentators on the movement, and often by the philosopher himself) as to whether it is really "existentialist" at all. Heidegger, while eschewing all labels, insists that his work is a "fundamental ontology," a kind of meta-metaphysics. Jaspers has referred to his philosophy in recent years as "periechontology." As to Sartre see infra notes 95, 220. Such disputes for the most part are no more than superficial. But in the case of Lavelle the argument becomes cogent and significant: see, e.g., the treatment in I. M. Bockensm, Contemporary European Philosophy 157, 208-209 (trans. by D. Nicholl and K. Aschenbrenner, 1956). And cf. on the so-called Thomist existentialists infra note 19.

12 Whose death in June, 1965, is a loss to humanism generally as well as to Judaism. See esp. his ICh UNd Du (1923) trans. in English as I and Thou (1937); Between MaN AND MAN (1947), a translation of several shorter German writings; RIGHT AND Wrono: An Interpretation of Some Psalms (1952), reprinted in his Good and Evil: Two Interpretations (1953). All the above are translated by $R$. Gregor Smith. And see the letters by Professor Buber published in Franz Rosenzweio, On Jewish Education (ed. by N. N. Glatzer, 1954) under the heading "Letters to Franz Rosenzweig on the Law"; and his W. A. White Memorial Lectures printed in 20 Psychiatry (No. 2) 97-129 (1957). Cf. the comprehensive studies in The Prilosophy op Martin Buber (ed. by P. A. Schilpp and M. S. Friedman, 1961), and in Paul Pruetze, The Socual Selp (1954), reprinted with revisions under the title SElF, Society, Exrstbnce (1961).

18 See esp. Tillich's Interpretation of History (1936), Love, Power and Justice (1954) and Theolooy op Culture (1959) (and cf. as to the last two works G. A. Lindbeck, Natural Law in the Thought of Paul Tillich, 7 Natural Law Forum 84 [1962]); and Bultmann's Geschichte und Eschatologis (1958), Essays Philosophical and Theological (trans. by J. C. Grieg, 1955), and Existence and Faith (trans. and ed. by S. M. Ogden, 1961) (and cf. John Macouarrig, An Existentialist Thzolooy: A Comparison of Hemegger and Bultmann [1955]; H. P. OWen, Revelation and ExistencB [1957]). My friend R. C. L. Moffat is currently engaged in jurisprudential studies of Bultmann and other modern Protestant theologians influenced by existentialism.

19 See esp. Gilson's God and Philosophy (1941) and L'Etre ex l'Essence (1948); and Maritain's Scholasticism and Politics (1940), The Rights of Man and Natural Law (1943), The Person and the Common Good (1947), Existence and the Existent (1948), Man and the State (1951), The Ranor op Reason (1952), and 
say, not only to theologically minded but to legally minded audiences. But in all these cases, the ideas and techniques that brand thought as "existentialist" are already to be found in Heidegger, Jaspers, or Sartre.

Again, if we look backward, it is clear that our description of these three as "the immediate founding fathers" of existentialism is tenable only if the word "immediate" is heavily emphasized. If a birth time of modern existentialism can be fixed at all, and if its paternity can be imputed to any single thinker, we must probably say that it was born in Denmark, fathered by Sören Kierkegaard (1813-1855), that eccentric and almost pathologically introverted thinker who "against the theoretical philosophy of Hegel and his predecessors ... pitted a mode of reflection closer to the individual's concrete existence."20 Yet if we are to consider inspirers of existentialism, we cannot stop with Kierkegaard. We must certainly come forward a little to include Nietzsche, ${ }^{21}$ and go back at least to Pascal, for most of the essential existentialist ideas and obsessions are already to be found full-grown in the Pensées. Clearly, an attempt to trace all the philosophical sources and precursors of existentialism would make our canvas impossibly wide.

Nor can we here attempt, as do more comprehensive efforts to place existentialism in its context in the stream of human culture, to take adequate account of its literary as distinct from its philosophical sources. ${ }^{22}$ Many

Moral Philosopry (1964). The doubts above referred to arise from a certain incongruity between Thomism and existentialism; and also perhaps from the inherent "respectability" of these writers. But as to Maritain any lingering doubts seem to be removed by his last cited work of 1964 , discussed more fully infra note 179 , where in a framework of exposition and criticism of certain past philosophers he in fact builds up his own personal philosophic weltanschauung. The genuine Kierkegaardian flavor is unmistakable throughout. As to Gilson see John T. Noonan, Jr., The Existentialism of Etienne Gilson, 24 NEw Scholasticism 417-438 (1950). And cf. generally H. Meyer, Martin Heidegger und Thomas von AQuin (1964).

20 Walter KaufManN, Existentialism from Dostoevsky to Sartre 83 (1956). Maurice Merlau-Ponty, Sens et Non-sens 125-130 (1948), has pointed out that Kierkegaard's attack is valid only against the later Hegel, whose earlier PḦ̈NOMENOLOGIE DES GEISTES (1807) stopped short of a logically closed system and in several respects foreshadowed the emphasis on individuality and irrationality of the existentialists themselves. On the details of Kierkegaard's attack, see Fernando Molina, Existentialism as PhiLOSOPHY 5-19 (1962); and on the antirationalism of existentialism generally, WiLliaM Barretr, Irrational Man (1961) (both books excellent). And cf. on both points infra pp. 100-102. See also Emmanuel Mounier, Existentialist Philosophies: An IntroDUCTION, esp. at 20 (translated by E. Blow, 1948); and the definite statement by JEAN Wahl, Les Philosophies de l'Existence 20 (2nd ed. 1958).

21 On the application of Nietzsche's philosophy to law see Thomas A. Cowan, Nietzsche, 14 Vanderbilt Law Review 151 (1960); Charles Boasson, On the Social and Legal Philosopher's Encounter with Nietzsche, 49 Archiv für Rechts- und Sozialphilosophie 447 (1963). And see infra p. 134.

22 See, e.g., works of KAUfMANN and BARretr cited supra note 20. The former has selected passages and Introductory Notes for both Dostoevsky (52-82) and Kafka (121-130), besides Rainer Maria Rilke (113-120) and Albert Camus (312-315). He also includes in his selection from Sartre a sample of that writer's literary work (223-240). BARRETT brings even such sober figures as Wordsworth (110-112) into at least a quasi-existentialist fold. And see generally $i d$. chs. 3,6 . 
novelists have dealt with themes and ideas so close to those of existentialism that they are sometimes treated as existentialists themselves. The classic examples are Dostoevsky and Kafka, both of whom undoubtedly influenced existentialism at its roots; and a whole generation of French writers must now be added. Yet the fact remains that all these writers deal with their ideas as novelists, not as philosophers; and if we were once to venture into the field of literature, we would have to admit that the leading ideas of existentialism have been thrashed out in fiction, poetry, and drama at least since the time of Sophocles' Oedipus Rex. ${ }^{23}$ Nor is this surprising once we appreciate that the central concern of existentialism is with the potentialities and the mysteries of human personality. For these have always been fertile ground for literary exploration; what makes existentialism distinctive is only its attempt to bring these literary themes into the realm of technical philosophical probing and building.

Whether they are appropriate themes for philosophizing is of course another question. Many philosophers would hold that they are not; and while this view may be rooted merely in the prejudice already referred to, ${ }^{24}$ it may also offer a respectable basis for rejection. Bertrand Russell, for instance, after a rational (if somewhat unfair) examination of some existentialist doctrines, concludes that they are mostly "psychological observations made to pass for logic."25 Yet "psychological observations" are just what the doctrines of existentialism are not.26 Though it may (as we shall see) be complementary to and even stimulating for psychology, existentialism is explicitly concerned to approach its subject matter in a philosophical way. For this very reason it seems better to avoid in the present survey merely literary discussions of the human situation, however profound and even existentiell they may be. So that on this ground, too, it seems best to restrict our study to what can be drawn from the philosophical writings of Heidegger, Jaspers, and Sartre - with an occasional backward glance to Kierkegaard and Nietzsche.

${ }^{23}$ The main existentialist significance of which arises after Oedipus has discovered his guilt, when he inflicts on himself the symbolic blindness which depicts his previous inner blindness, apparently in answer to a need to show himself to others as he is for himself. See also on Oedipus, KarL Jaspers, Von DER WaHrhert 934-936 (1947); and in English translation KarL JaSpers, TragedY Is Not ENovgh $57-61$ (1953; a translation by $\mathrm{H}$. A. Reiche, H. T. Moore, and K. W. Deutsch of pp. 915-961 of Von Der WAhrheIt). And cf. C. and W. Russeli, Human Behavior: A New Approach 370 ff., esp. 389 (1961).

24 Or even (as some existentialists would no doubt suggest) in the critics' own existential discomfort or their Sartrian "fear and shame" - i.e., in a feeling that intimate existential facts like human death and human emptiness should not be discussed in public, or at least not subjected to close analytical inquiry.

25 See Bertrand Russell, Wisdom of the West 302-305, at 303 (1959).

26 Jaspers was a distinguished psychiatrist before he became a philosopher (see his AlLGEmeine Psychopathologie (6th ed., 1953); K. Kolle, Karl Jaspers as Psychopathologist, in The Philosophy op Karl Jaspers 437 (ed. by P. A. Schilpp, 1957); L. B. Lefebre, The Psychology of Karl Jaspers, in the same work at 467). But this proves nothing about 


\section{B. The "Structure" of Existentialism.-For all three of these thinkers,} we can immediately sound certain constant leitmotifs, which if they are constantly kept in mind ${ }^{27}$ should help readers to find their way, not only through the present discussion, but through the forbidding masses of the existentialist writings themselves. ${ }^{28}$ First, existentialism purports to be an unusually radical ontology, a philosophical inquiry into the nature of "Being." Second, it

his philosophy, any more than the facts that he was once a law student, or that Heidegger was a student for the priesthood. Nor is it here relevant that Sartre has envisaged the use of existentialist concepts as the theoretical basis for an "existentialist psychoanalysis," or that something like this has actually been done by some psychologists and psychotherapists (see infra note 177). The existentialist positions cannot themselves be reached by mere empirical observation, any more than by mere ratiocination and intellectual deduction. Indeed, existentialism offers vigorous polemics against the unwarranted extension of empirical science into every field of human activity. See, e.g., precisely as to psychoanalysis, KarL JASPERS, VerNuNFT UND WIDERVRRNUNFT IN UNSERER ZeIT, Lecture I (1950); and English translation by S. Goodman, Reason and ANTi-Reason in Our Time (1952).

${ }^{27}$ The extreme difficulty of generalizing about a movement so diverse and so subject to internal hostilities should, of course, also be kept in mind. See supra p. 72.

$28 \mathrm{Cf}$. the alternative list of six common features offered by BOcHENsKr, op. cit. supra note 16, at 159-160. These are (1) the rooting of philosophy in a highly personal, "existential" experience (Jaspers' "brittleness," Heidegger's "being-unto-death," Sartre's "nausea"); (2) the taking of "existence," meaning "a peculiarly human mode of being," as the supreme object of philosophical inquiry; (3) the conception of existence as "absolutely actualistic; it never is but freely creates itself, it becomes; it is a pro-jection; with each instant it is more (and less) than it is"; (4) the view of such existence as pure subjectivity; (5) the view of such existence as not self-contained, but "inserted into the world, so that man ... not only faces a determinate situation but is his situation," bound "tightly and necessarily to the world and to other men in particular"; and (6) the repudiation of the distinction between subject and object, so that objective knowledge is philosophically invalidated, to be supplanted by experience of reality.

The second item in Bochenski's list is often summed up (notably by JEAN-PAuL Sartre, L'Existentialisme est un Humanisme 17 [1946], and English translation in Kaupman, op. cit. supra note 20, at 289) in the formula "Existence is prior to essence." So long as this is understood merely as a slogan-like formulation of philosophic priorities ("Let us find out about human existence before we worry about essences"; "[Human] existence is - cognitively - prior to anything else"), it seems harmless enough. But because the formula is presented almost ad nauseam in the swelling flood of commentaries on existentialism, as itself supposedly constituting the "essence" (!) of the movement, it seems important to stress that if we try to give it anything more than the above simple programmatic significance, we cannot really make it meaningful at all. It might mean that "existences" are in some sense ontologically prior to "essences," in a curious kind of reversal of Plato's doctrine of Ideas. But some existentialists might be content with Plato's doctrine as it stands: see, e.g., as to Jaspers' view of worldly phenomena as "ciphers of the Transcendent," Bocrensxi, op. cit. 185. And those existentialists who would reject Plato's doctrine would do so, not because they reverse the Platonic priorities between "existence" and "essence," but because they deny any reality to "essence" in Plato's sense. Alternatively the formula might mean that the human self first of all "exists" and only afterwards becomes an "essence," making its essence out of its existence; or more simply that there is no such thing as a human "essence" preceding the creative experience of existence. But this poses insuperable difficulties in consistent understanding of the concept of "authenticity." Some of these will be discussed at the end of this section: see esp. infra notes 92, 93. Accordingly, it has here seemed safest to avoid the above formula altogether. It seems in any case to be used only by interpreters of existentialism, never by the existentialists themselves. Sartre himself in his 1946 lecture cited above is speaking, not as an existentialist, but as an apologist or popular interpreter of the movement: and though Heidegger sometimes comes close to using such a formulation, he never quite does so. The nearest approach is in his SEIN UND ZEIT 42 ff. (7th ed., 1953); and English translation by J. Macquarrie and E. Robinson, Being and Time 67 ff. (1962). 
purports to be an equally radical humanism, a philosophical inquiry into the nature of human personality. Third, its philosophical method consists of variants of Edmund Husserl's phenomenology. Fourth, it is a linguistic philosophy, in the sense that its working is intimately dependent on certain unique conceptions of language. Fifth, it works always in a basic framework which distinguishes two levels of human existence: the "inauthentic" level of mere physical presence or "thingness," and the "authentic" level which transcends this. Sixth, "authenticity" is thereby set up as a value concept, indeed as the existentialist value.

Each of these common features needs to be elaborated at some length. First, then, existentialism lays claim to a fundamental concern with ontology. ${ }^{29}$ For all of its exponents (but particularly for Heidegger, the most determined "onto-logist" of our time) $)^{30}$ the probing of human nature and human values, human reality and human potentials, is merely a process of piercing the veils which keep us from knowledge of Being, or of finding the guideposts which help us to this knowledge. But the mere choice of this kind of path to ontological understanding is a radical departure from traditional ontologies. This is a "new,"31 a humanly oriented ontology, which insists that only man can answer ontological questions, because only man can ask them; that asking questions, making inquiries, is itself a mode of Being; and that man himself in asking these questions is therefore what he is asking about. There is an inseparable link - not of circularity, but of "relatedness backward or forward" - between questioner and answer, between man and Being. ${ }^{32}$

The position is nicely clarified by Kurt Hoffman in his account of Jaspers' philosophy. For Jaspers, he says, philosophy is unequivocally

a search for Being. . . . But it matters, for this philosophy, who asks the question as to the nature of this Being: man's concrete historical situation enters into the question and into the answer. In each individual, in all his insecurity and disquiet, philosophy must make a new start;

29 Sce Michael Wyschoorod, Kirrkegand and Hemegorr: The Ontology op Existence (1954); E. A. Tiryakinan, Sociologism and Existentialis 74 (1962); and cf. Tillich, Love, Power and Justice 18-24 (1954). There have been a number of existentialist-inspired attempts to create an "ontology of law": probably the most fruitful are in Tammelo, article cited supra note 16, and Nicos Poulantzas, Vers une Ontologie Juridique Actuelle, 50 ARchiv für Rechts- UND SozlalphilosophIE 183 (1964). No such attempt will here be made.

so See Molins, op. cit. supra note 20 , at 53-72; Bockenskr, op. cit. supra note 16 , at 161-172; M. Grene, Dreadful Freedom $47-48$ (1948, or later reprints under the title Introduction to Existentialism); Tiryakian, op. cit. supra note 29 , at 75 . And see W. J. Richardson, S.J., Heidegoer: Throvoh Phenomenolooy to Thouoht (1963) (with Preface by Heidegger), which while outdoing the master himself in exotic verbal formulations, must surely become the standard critical apparatus in the Heideggerian field.

s1 Cf. Jean Wahl, Vers la Fin de l'Ontologle: Etude sur l'Introduction dans la MetaphysiQue par Heideooer 18 ff. (1956).

32 Hemecorr, Sein und Zrit 5-8; 11-19 (Beino and Time 24-28; 32-40). 
hence it is always in process and always in suspension, it is never complete and final and can never be set forth in the form of a universally and eternally valid doctrine. ${ }^{33}$

This view points us to another departure from traditional ontologies, which tend to interpret Being in terms of some abstract, abiding "essence" of things. Existentialist ontology is both more and less than this - less, because of its rootedness in subjective historicity, and more, because it seeks to press beyond "beings" to "Being," beyond entities and phenomena and even "essences," to the encompassing ontological foundation of all these. ${ }^{34}$ Abstract "essences". are merely part of the rationalistic "projection" which man puts between himself and Being, and which the existentialist ontologist seeks to dissolve.

Secondly, existentialism is the philosophy of the self; its followers all share the Kierkegaardian anxiety to get at "the individual's concrete existence."35 In part, this anxiety arises from the attempt to approach the questions of ontology through the human personality in which the questions arise, and which therefore shapes the questions and at the same time offers the most accessible exemplar of the answers. To the extent that this is the explanation of the preoccupation with self, we must say that what has thus begun as a mere starting point for ontology has turned into an almost total obsession, to the virtual exclusion of the ontological purpose. Heidegger's Sein und Zeit symbolizes this strikingly: the analysis of human existence of which it consists is offered only as a preliminary foundation for the interpretation of Being. At the end of the book we are told that this latter problem is not one we can simply " 'bluster into'; it is of the kind which cannot get enkindled unless preparations are made for it. Towards this alone the foregoing investigation is on the way."36 And the whole volume is designated "Sein und Zeit: Erste Hälfte." But no Zweite Hälfte has ever appeared, nor will it. ${ }^{37}$

${ }^{33} \mathrm{~K}$. Hoffman, The Basic Concepts of Jaspers Philosophy, in The Philosophy of KarL JAspers, cited supra note 26, 95, at 96. Cf. Jaspers' own clarification in Von Der WAHRHEIT 84: "Being is not produced by us; it is not mere interpretation. . . . Rather, by its own impetus, it causes us to interpret and will not permit our interpretation ever to be satisfied." And cf. the passage from Heidegger quoted infra at note 115 .

34 See Heidegoer, Sein und Zeit 28 ff., esp. at 37 (Beino and Time 50 ff., esp. at 61); Wahl, op. cit. supra note 31 , at 53; Thomas Langan, The Meaning of Heidegger: A Gritical Study of an Existentialist Phenomenology 74 (1959); Tiryakian, op. cit. supra note 29 , at $104-105$.

${ }^{35}$ See, e.g., the various passages from Kierkegaard reprinted in KaUfManN, op. cit. supra note 20, at 83-99. And see the brilliant account by Maritain in his 1964 work cited supra note 19, at 354-370. Cf. also James Collins, The Mind of KierkegaArd (1953).

${ }^{38}$ Sein und Zeit 437 (Beino and Time 487-488).

37 Cf. E. L. Allen, Existentialism from Within 24 (1953). In the seventh edition of SEIN UND ZEIT, in 1953, Heidegger finally deleted from the title page the words "Erste 
Yet the existentialist preoccupation with human existence cannot be explained merely as another example of what Nietzsche castigated as "the commonest stupidity": that is, "forgetting what one is trying to do."38 It is rather directed to making us concentrate on what we are trying to do. And the important thing here is what we are trying to do: the existentialist seeks to goad every man into confronting the question, What do $I$ want to do with my life?

As this question was posed by Kierkegaard, it had three main kinds of significance. First, and most important for him, it was a religious question, thrusting each man into terrible aloneness before God and challenging him to commit himself to God. Second, and consequentially, it was a protest against the tyranny of "the crowd," the submergence of the individual in an easy communal life which would blunt and obscure his awareness of his responsibility before God. Third, and again consequentially on the religious significance of the question, it was a protest against the intrusion into theology of systematic rationalism. For Kierkegaard religious belief could not be reached by philosophical speculation, but only by a "leap" of faith, a leap into commitment. 39 "God is a subject, and therefore exists only for subjectivity in inwardness." 40 It was above all this last conviction that led Kierkegaard - and existentialism - into their endless probing of the subjective inwardness of the human individual.

But the continued probing of this inwardness shares all three of these kinds of significance. First, the religious orientation lives on in the twin facts that most modern theology now has an existentialist flavor, and all modern existentialism has a theological flavor. The existentialist "may deny God but cannot be indifferent to him." 41 The important thing is that whatever my

Halfte," explaining in a Preface that "After a quarter of a century, the second half could no longer be added unless the first were to be presented anew. Yet the road it has taken remains even today a necessary one." See Sein und ZeIt vi (Being and Time 17).

38 Friedrich Nietzsche, The Wanderer and his Shadow, Aphorism 206 (1879), in 4 Nietzsches Werke 305 (Taschen-Ausgabe, 1906), and English translation by P. V. Cohn in 7 Complete Works of Friedrich Nietzsche 297 (ed. by Oscar Levy, 1911). On at least two occasions Lon Fuller has made telling use of this aphorism to express his own abiding preoccupation with the "purposes" of legal philosophy. See op. cit. infra note 85 , at 41 ; op cit. supra note 6 , at 95 .

30 Sören Kierkegaard, Fear and Tremblino (1843), in 5 Sören Kierkegaard: Samlede Vaerker (ed. by A. Drachmann, J. Heiberg, and H. Lange, 1963). And see the English translation by Walter Lowrie (1941; reprinted with improvements 1954), where the passage in question is at $44 \mathrm{ff}$. In a footnote at 53 Kierkegaard sums up the whole theme, quoting the line of poetry: "Ein seliger Sprung in die Ewigkeit" ("A blissful leap into eternity"). And see Grene, op. cit. supra note 30, at 18, 30-32; MounIER, op. cit. supra note 20 , at $29-31$.

40 Sören Kierkegand, Concluding Unscientific Postscript (1845), in 9 Samlede VAERKER 166 (edition cited supra note 39); and English translation by Jean T. Wilde and W. Kimmel in their collection The Seargh for Bring, 49-96 at 73 (1962).

41 Allen, op. cit. supra note 37, at 19. 
religious position may be, it must be an exercise of my freedom, not a secondhand position adopted through reliance on a church or creed. ${ }^{42}$ This view is a good illustration of how, second, the antipathy to "mass man" lives on in the shared determination to defend individuality against the ever-increasing encroachments of public and group opinion, of collectivized and socialized life. This proselytizing, ethical campaign against collectivization operates in all the existentialists, as it did in Kierkegaard, as a major stimulus to their emphasis on the individual which is quite independent of any analytical propositions they want to make about how human existence is. The existentialist conception of a self-aware, self-acting, self-creating individual is offered not only as a description of what human life is like, but as an urgent, impassioned prescription of what it ought to be like. The campaign is not, of course, a political one against the welfare state, or a sociological one against mass advertising media; it is a spiritual campaign against what I may allow these external forces to do to my inwardness - a campaign against the collectivization of my self. Third, and conversely, the subjectivism of Kierkegaard is of crucial importance for the descriptive side of existentialism. The emphasis on subjectivity, and the corresponding antipathy to "systems," mean that philosophical ideas are valid not to the extent that they are rationalized, but to the extent that they are lived. "The truth of a situation is only grasped when it is seen from within, by those who are living through it." 43 This, for Kierkegaard, and again for existentialism generally, is the secret of Socrates' greatness as a thinker.44 For "an objective uncertainty held fast in

42 See esp. Karl Jaspers, Einführung in die Philosophie 42 ff. (1950); and English translation by R. Manheim, WAY ro WISDOM 42 ff. (1954).

43 Allen, op. cit. supra note 37, at 8. And see Kierkegand, Concluding UnscienTIFIG POSTsCript, passim.

14 See Concluding Unscizntific Postscript 168 (The Search por Being 74-75). The immortality of the soul, for example (Kierkegaard here says), is approached by most modern philosophers in terms of "three proofs":

But Socrates! He puts the question objectively in a problematic manner: if there is an immortality ... on this "if" he risks his entire life, he has the courage to meet death, and he has with the passion of the infinite so determined the pattern of his life that it must be found acceptable - if there is an immortality. Can any better proof be given for the immortality of the soul? But those who have the three proofs do not at all determine their lives in conformity therewith; if there is an immortality, it must feel disgust over their manner of life: can any better refutation be given of the three proofs? The "bit" of uncertainty that Socrates had helped him, because he himself contributed the passion of the infinite; the three proofs that the others have do not profit them at all, because they are and remain dead to spirit and enthusiasm, and their three proofs, in lieu of proving anything else, prove just this. . The Socratic ignorance, which Socrates held fast with the entire passion of his inwardness, was thus an expression for the principle that the eternal truth is related to an existing individual, and that this truth must therefore be a paradox for him as long as he exists; and yet it is possible that there was more truth in the Socratic ignorance as it was in him, than in the entire objective truth of the System .... 
an appropriation-process of the most passionate inwardness is the truth, the highest truth attainable for an existing individual."45 This truth is in the individual, and the individual is "in the truth." So that the study of the individual is not only a convenient jumping-off point in the search for Being; it is in this study that any human searcher must find his answer.

Kierkegaard's introverted subjectivism is, in short, the fundamental or general motivation by which the existentialists are driven to conduct their search for Being in terms of an analysis of human existence. But the immediate, specific motivation is much more recent than this. The third generalization which we offered about existentialism was that its method of philosophical inquiry is that of phenomenology; and to this we now turn.

For its founder, Edmund Husserl, ${ }^{46}$ phenomenology was a reflecting upon our modes of perception of the world in order to discover, and thereafter to set aside, the intellectual presuppositions which color our perceptions; and to look in this way to the phenomena themselves. The general existentialist approach to the question of Being through the being of the questioner is merely an application of this methodology. But in the hands of different existentialists the method takes different forms. At one extreme is Heidegger, for whom in his later writings ${ }^{47}$ the search for Being becomes a completely passive process of "understanding," in which we simply hold ourselves open to the openness of Being. At the other extreme is Sartre, whose philosophy, beneath its laborious system-building, is at heart a brusquely impatient attempt "to grasp existence in the act itself, in which it fulfils itself." 48 Somewhere

45 Concludino Unscientific Postscript 169-170 (The Search for Beino 76).

40 See EdMUnd Husserl, Ideen zU einer reinen Phänomenolootr UND PhäNombnologischen Philosophie (1913, 3rd ed., 1928); and English translation by W. R. Boyce Gibson, Ideas: Genkral Introduction ro Pure Phenomenology (1931). For excellent introductions to phenomenology see M. Natanson, Phenomenology: A Viewing, 10 Metrodos 295 (1958), and Molins, op. cit. supra note 20, at 31-52. And for a short but clear summary, well placing Husserl in the scheme of German philosophy generally at his time, see Joseph L. Kunz, Latin-American Philosophy of Law in the Twentieth Century, 24 New York UnIversity Law Quarterly Review, 283, 473, 801, at 493-496 (1949). Phenomenology has had a considerable influence on Latin-American legal philosophy, and in the English-speaking world promising exploratory studies have been carried out (but not published) by A. A. Fatouros in the United States and Lyndel V. Prott in Australia. Much more work remains to be done, in particular on the question of how far the analysis of concepts like "a right" and "a legal person" would be facilitated by subjecting them to a phenomenological reduction. I have, however, thought it better to exclude these questions from the present study, leaving them to those who prefer to take their phenomenology straight.

47 The earlier Heidegger was probably more scrupulous in his adherence to the Husserlian schema than any other existentialist writer: see citations supra note 34 and Richardson, op. cit. supra note 30 . This phase of Heidegger's work has indeed been rebuked by JAsPERs, work first cited supra note 26 , at 649 , for its excessive striving to reduce Being to knowledge. See H. Kunz, Critique of Jaspers' Concept of Transcendence, in Thr PhrlosoPHY OP KARL JASPERS, also cited supra note 26, 499, at 502.

48 See Simone de Beauvoir, Littérature et Métaphysique, in Les Temps Modernes (April, 1946) 159-160. 
in between these extremes is the philosophical method of Jaspers. With him, as with Sartre, philosophy is a reaching-out for Being. But whereas Sartre's highly technical philosophy proceeds as if its phenomenological talons can close once for all on Being, Jaspers' philosophy accepts the fact that it can never grasp what it is reaching out for. It is an endless struggle to transcend the unsurmountable limits of human existence.

This struggle, moreover, may take place on three different levels. Although, like the other existentialists, Jaspers denies that "empirical" or "scientific" or "objective" or "worldly" knowledge can be of any ultimate help in the search for Being, he does concede to this kind of knowledge a certain (though still an incomplete) validity; and this concession enables us to add "the world" to "the self" and to "Being" as a third main axis of orientation for (Jaspers') existentialist concern. For Jaspers each of these axes has its own kind of Being, and its own kind of struggle. On the lowest level, that of "world-orientation," the philosophical endeavor "raises the world from its condition of inert objectivity and stretches out towards the uttermost limits of its range." 49 On the level of the self, the struggle begins from the human personality as the outer limit of the "worldly,", and reaches towards the authentic self which may truly be called Existenz. (This dichotomy is a central feature of all existentialist writings: what Jaspers does is to broaden its context by extending it at either end.) Finally, on the level of Beingitself, the struggle begins from authentic Existenz, which is a reaching towards Transcendence. These three kinds of struggle for Being may thus be seen as one after all: a progressive advance from the world towards Being, in which the crucial stage, and the one on which Jaspers, like all existentialists, therefore concentrates, is the mediating advance from man as an object of inquiry, to human nature as Existenz. ${ }^{50}$

In the former sense, man can be the object of ordinary knowledge gained through ordinary perceptions; ${ }^{51}$ but in the latter sense, the important one, man cannot be an "object" of knowledge because he cannot be an "object" at all. He is "the nonobject which man is and of which he becomes aware when he achieves authentic awareness of himself."52 To reach this awareness of ourselves we must struggle to transcend ourselves - constantly, but also patiently and humbly. The human personality is made up of potentialities; and outstanding among these, because it is necessary to the fulfilment of

49 BochensKI, op. cit. supra note 16 , at 187 . Bochenski's summary at 186-187 of Jaspers' threefold orientation, and its relation to the three Kantian "ideas" of the world, the soul, and God, has been of great assistance in organizing the above paragraph.

${ }^{30}$ See generally Kunz, essay cited supra note 47, at $503 \mathrm{ff}$.

51 Including the perceptions of the social sciences. See infra p. 120.

52 Jaspers, Einführung in die Philosophie 61 (Way to Wisdom 63). 
all the others, is "the universal readiness for communication."53 This includes communication with oneself, with others, and with Being itself. The tool is Reason, which points "both to that unattainable One, whose infinite attraction makes Reason think, and to the origins, which, brought to life by Reason, attain the power of speech. Reason brings it about that what is and can be must unfold itself."54 The way is "boundless communication of the historically different in never-ending dialogue, rising to heights of noble emulation."55

Jaspers' concept of communication deserves special emphasis here because of the importance which it will assume when we come to refer to the possibilities of justice. For Jaspers, communication in his extended and inexhaustible sense is the only possible basis for the unity of mankind, which in turn is a prerequisite for the realization of the highest human potentialities. ${ }^{56}$ This boundless communication, carried on not in conventional language but in a deeper "dialogue" in the existential sense - a dialogue of Existenzen, a dialogue of men in their historicity ${ }^{57}$ - is inseparably linked with political free-

53 Einführuno in die Philosophie 87 (Way to Wisdom 91).

54 Jaspers, Vernunft Und Widervernunft in Unserer Zeit (Reason and ANtiReason in OUR Time 42 ).

55 Einführung in die Philosophir 102 (Way to Wisdom 106). Cf. F. Kaufmann, Karl Jaspers and a Philosophy of Communication, in The Philosophy of Karl Jaspers, cited supra note 26 , at 211-295.

${ }^{56} \mathrm{Cf}$. in the same work Hannah Arendt, Karl Jaspers: Citizen of the World, at 539-549.

57 On "'historicity" as one of Jaspers' key concepts see EINFüHruno In DIE Philosophie 45 (WAY TO WISDOM 47): "The individual, always in his own historicity, stands . . . in an immediate, independent relation to God that requires no intermediary." Cf. generally J. Henning, Karl Jaspers' Attitude towards History, in The Phrlosophy of Kard JasPERS, cited supra note 26, at 565-591. And see the Introduction by J. T, Wilde, W. Kluback, and W. Kimmel to their translation of pp. 1022-1054 of VoN DER WAHrheIt as Truth AND Symbor (1959), at 10n.: "In the encounter with Transcendence I discover the fundamental origin and condition of my selfhood. I discover myself to be 'given to myself as possibility, obligation and task. I discover that my being is $m y$ being in the unconditioned freedom, possibility and claim of the unrepeatable, historical moment."

The existentialist stress on "historicity" is not of course peculiar to Jaspers. It points both to the uniqueness of the "historical moment," and to the context of this in a continuing dimension of time. It has been argued that the supposed incompatibility between existentialism and natural law (supra note 19, infra pp. 122-23) arises only because the latter has commonly been regarded as standing outside this ongoing historical stream. When (it is said) natural law is seen not as "ahistorical" but as "transhistorical," existence can be seen to "participate" in the continuing "evolution" of this transcendent and yet temporal basis. "Natural law is never completed, but rather always discovered more deeply." And from this dimension stretching out in time "our total historical existence derives its ascending dynamics and meaning." See M. G. Plattel, O.P., Personal Response and the Natural Law, 7 Natural Law Forum 16, at 16-21 (1962), esp. at 20, where the words above quoted occur. This formulation, however, still seems to imply the simplistic assumption that the continuous unfolding of natural law in its historicity is a matter of automatic progress, in which "evolution" unfalteringly and unswervingly proceeds in "a continued growth toward truth." The more modest formulation of the same theme by Arthur Kaufmann, in his works cited supra note 12, is also, therefore, more forcible. And cf. Hoмmes, op. cit. supra note 13 , at $40 \mathrm{ff}$.

In any event, Julius Stone has reached a substantively identical position in a way which is emphatically independent of both natural law and existentialism. See on the 
dom for all, and with constitutional justice. ${ }^{58}$ Part of the patient progress of Reason is "ever deepening communication": 59

Reason is one with the boundless will to communication. Reason, because it is intent on and open to the One in all that is, refuses to break off communication... Reason demands that the risk of communication should be taken again and again ... Truth is bound up with communication. Truth that cannot be communicated becomes identical with untruth. Truth that binds itself to communication is not complete; it listens for an echo as it communicates itself, testing itself and the other. It is distinct from all one-sided proclamation. It is not I who bring the truth by myself; I can only seek for truth, along with the other who meets me, by listening, asking and testing. ${ }^{60}$

This broadened concept of communication brings us to the fourth generalization foreshadowed above, which turns on the distinctive existentialist attitudes to language. The voluminous existentialist writings are usually not attempts to present orderly arguments for systematic philosophical theses, but attempts to communicate subjective or transcendental realities for which ordinary objectivizing language is an inadequate means of communication, and at the same time forms part of the subjective reality to be communicated. On the one hand, therefore, the existentialist strives to extend the role of his language, making it serve the functions not only of verbalized communication but of other less formalized kinds of communicating and of communing $;^{\mathbf{6 1}}$ while on the other hand, he strives to make his language not merely a

historically given "enclaves" of justice his work cited supra note 1, at 318-321, 340-355. In his companion work cited infra note 155 , at 546 , he sums the matter up by saying that "paradoxically, while justice as a normative entity transcends human history in the sense that men's aspirations to move by its light seem irrepressible even through eras of greatest darkness, the approach to understanding justice must still be through history itself." Cf. the same work at 110; and for the basic motivating ideas of this nonexistentialist version of "historicity," see his Comment on " 'Reason' and the Time-Dimension of Knowledge," 48 ARGhiv für Reghts- UND Sozialphilosophie 95 (1962), partly racapitulated in his work cited supra note 2, at 3-5 (and cf. 7). Whether this stress on "historicity" suffices to make Stone a kind of existentialist malgré lui is probably a meaningless question. Cf. supra note 16.

58 See Einführuno in die Philosophie 102 (Way to Wisdom 107).

59 See Von der Wakrheit 961 (Tragedy is Not ENovgh 105).

0 See Vernunft und Widervernunft in UNSERER Zeit 36 (Reason and ANTiReason in OUr Time 42-43). And cf. Fuller, op. cit. supra note 6, at 185-186; and A. R. Blackshield, Empiricist and Rationalist Theories of Justice, 48 ARchIV FÜR RBCHTSUND SOzIALPHILOSOPHIE 25, at $81 \mathrm{ff}$. (1962).

61 I.e., functions analogous to introspection, "proprioception," empathic sharing of a feeling, the mere having of a feeling, the contemplation of a sunset, or the touch of a stranger's elbow in the street. On such nonverbal experiences as at least quasi communications, see Ilmar Tammelo and Anthony Blackshield, The Meaning of Meaninglessness, 5 Malaya Law Revisw 1, at 7 (1963). 
record of an argument, ${ }^{62}$ but itself an argument, in which words become protagonists and multiple verbalizations become truth. ${ }^{63}$

The result, as may already be obvious, is that the language of existentialists is at once very dramatic and very obscure. At times they deliberately adopt a bizarre way of talking, in an attempt to jolt our minds back to subjects that we have forgotten to think about, or have schooled ourselves not to think about. At other times the ideas they are trying to express lie so deep in the most intimate and tenuous reaches of the human personality (or so far up in the transcendence of Being) as to be totally inexpressible in ordinary language. To appreciate what the existentialists are saying we must remember, first, that what they say is only meant metaphorically, and secondly that in any case their extreme intensity of expression must be diluted and understood in the paler sense in which it is reflected in the grayness of our own personalities. (Precisely this grayness is, of course, one of the main things of which the existentialists seek to rid us; they really do seek to impress upon us that life is dramatic. The present point is only that in their anxiety to do this they sometimes make it sound even more dramatic than they intend.) ${ }^{64}$

These tendencies as to mode of expression are manifest in all three of our existentialist models; but here again the tendencies take different primary forms in each. Heidegger not only indulges in all the verbalizing tortuosity of scholastic terminology at its worst, ${ }^{65}$ but adds to this a constant and often irritating form of play upon his words, in which he breaks them up into their etymological parts so as to bring back in its original freshness their now buried meaning. ${ }^{66}$ Thus, Heidegger in his philosophy is not content to be "concerned" with the universe; instead he is "con-cerned" with it. Con means "with"; and for Heidegger "with," "in," "outside" (con-, in-, ex-), and all such prefixes denoting (metaphorically) positional relationships, cease to be mere prefixes and regain their full richness of meaning. Cernere (liter-

\footnotetext{
62 See Blackshield, article cited supra note 4, at 88-89.

63 See especially on Heidegger's verbal arguments Marjorie Grene, Authenticity: An Existential Virtue, 62 ETHics 266, at 267 (1952).

64 The difficulties of existentialist terminology and their potentials both for deepening and for blocking communications have now been fully considered by Stone, article cited supra note 8 at $149-150$, esp. nn. 17-19.

65 See Thomas Gilby, O.P., Principality and Polity 271-273, 278 (1958). The assumption that intellectual elaboration of the abstract scholastic metaphysical categories could be a viable and meaningful method of philosophy has already led once in human history to sterility of thought and ultimately to an inevitable nominalist skepticism. If jurisprudence is to take in existentialist infusions, the revival of such an assumption ought surely not to be one of them. Yet even so perceptive a thinker as Arthur Kaufmann has tended to allow the Heideggerian model to lead him into this trap. See, e.g., his 1963 article cited supra note 12 , at $83 \mathrm{ff}$.

${ }^{66}$ See TIryakian, op. cit. supra note 29, at 106, suggesting also that for Heidegger the very complexity and esotericism of his verbal constructs "protects the insight and verity they seek to convey from being too easily vulgarized, and thereby distorted."
} 
ally "to sift") is to "single out," to "distinguish" (cf. "discern"); and Heidegger's "con-cern" is thus, he says, to "see, and in seeing to call to oneself, ap-propriate." 67 So to con-cern oneself with something is to single it out and at the same time to call it to oneself and experience oneself with it. ${ }^{68}$ And this complex play on "con-cern," all indicated by a single hyphen, is but one among scores of similar examples throughout Heidegger's work.

In Jaspers, the emphasis is on words and expressions as "symbols" or "ciphers" of thought. For him, indeed, the whole world, with everything in it, is a cipher: ${ }^{69}$ that is, worldly phenomena can be understood not only as empirical objects of knowledge but also as the "hieroglyphics" or "symbols" of the "language" through which we may apprehend the reality of Being that is, the reality of Being itself in its highest mode of being, which is Transcendence, and by which Jaspers really means "God"70 (or rather, as Gerhard Knauss has nicely put it, "the concealment of God"). ${ }^{71}$ Two riders must be added to this idea of the world as cipher. First, the reality which is revealed through the cipher differs from empirical reality not only in degree but in kind; $;^{72}$ and second, the apprehension of God through the cipher is not the familiar pantheistic "proof" of God through knowable worldly things, for they must cease to be regarded as knowable worldly things before they can be understood as cipher. ${ }^{73}$ The decipherment of ciphers is, in short, a

6r See Martin Hemegger, Identität und Differenz 28-29 (1957); and English translation by K. F. Leidecker, EsSays in Mrtaphysics 27 (1960).

68 To say that Man is concerned with Being might also etymologically imply that Man and Being are sifted together. But Heidegger does not make this explicit.

69 See Kart Jaspers, 3 Philosophie ch. 4 (3rd ed., 1956).

70 Cf. Karl Jaspers, Rechenschaft UND Ausbick 264 (1951) (Transcendence is "the source and the goal, both of which lie in God and out of whose depths alone we really become authentically human"); KARL JASPERS, VON DER WAHRHEIT 111 ("To the extent that we are personally affected [by Transcendence] as individuals, to the extent that we enter as persons into a relation to Transcendence as Person, we call it God"); and KarL Jaspers, The Origin and Goal of History 219 (translated by M. Bullock, 1953) ("The Godhead is origin and goal; it is peace of mind. There is security. It is impossible for man to lose Transcendence, without ceasing to be man"). And see Kaufmann's essay cited supra note 55, at 270; and in the same work P. Ricoeur, The Relation of Jaspers' Philosophy to Religion, at 611-642, S. Holm, Jaspers' Philosophy of Religion, at 667-692, and A. Lichtigfield, The God-Concept in Jaspers' Philosophy, at 693-701.

${ }^{71}$ Cf. in the same work G. Knauss, The Concept of the "Encompassing" in Jaspers' Philosophy, 141, at 156 .

72 VON DER WAHRHeIT 1032 (TRUTH AND SYMBOL 41). As against this in turn it must be added that the significance of a cipher, and even its status as cipher, may be dependent on our individual and cultural experience: "the experience of Transcendence through ciphers varies along with the historical habitat of a given Existenz." See J. Thyssen, The Concept of "Foundering" in Jaspers' Philosophy, in The PHILOSOPHY OF KarL Jaspers, cited supra note 26, 297 at 308-309. And see generally on "ciphers" id. at 307-312. This "cultural relativity" of ciphers may extend to those put together by existentialism itself, and may explain the much greater fertility of these ciphers for German philosophers (including legal philosophers) than for their Anglo-Saxon counterparts, whose historical tradition acclimatizes them to philosophical ciphers of a plainer, blunter kind.

73 Einführung in die Philosophie 41-42 (Way to Wisdom 43-44). 
process altogether alien to our rationalist, scientific, logical operations of the mind when we inquire about the things of this world. This difference characterizes both the decipherment and the endless, laborious putting together of the immense collocation of ciphers which make up Jaspers' own philosophy.

With Sartre, the existentialist penchant for highly charged language reaches perhaps its extreme point. Most of Sartre's vivifying metaphors are physical (see, for instance, his detailed discussion of "nausea" and "viscosity" as philosophic concepts) $;^{74}$ and he seems, in a way that is certainly not true of the German existentialists, to intend his strong physical expressions to carry not only their philosophic and metaphorical significance, but also some literal significance.

We come now to the fifth and most difficult, but also the most important, of the preliminary clarifications that need to be made. I believe that much of what the existentialists have to say will be clearer if the reader can fit it around a certain basic framework common to all three of our chosen writers. This framework has already been sketched in my account of Jaspers' version of the struggle for Being, but it must now be described in more detail. It is a framework which distinguishes two levels of human existence, two "modes of being" - a higher and a lower, an authentic and an inauthentic. The first is Heidegger's and Jaspers' Dasein, literally "being-there," and meaning simply the physical fact of my being there, simply there, as a tangible thing - in the same way as every other thing in the objective world. This inauthentic, deadish mode of being, is more or less what Sartre means also when he speaks of "l'être-en-soi."

The second and authentic mode of human existence is existence conscious of itself, capable of knowing itself and controlling itself, planning things and exercising its own free will, asserting its individuality. This is the distinctively human mode of being. If we live only on the level of Dasein, no more humanly alive than animals or things, we are living in an inauthentic mode of being; and we have to struggle to rise to our authentic selfhood. If we are living on the authentic level, we have to struggle to stay there and not fall back into inauthentic being. Various kinds of thoughtlessness, stupidity, mob psychology and the like, which the existentialists and particularly Heidegger ${ }^{75}$ analyze in detail, can drag us back into inauthenticity.

74 For "viscosity" see Jean-Paul Sartre, L'Etre et le Néant 695-706 (1955 ed.); and English translation by Hazel E. Barnes, Being AND Nothingness 604-615 (1956). And cf. Mounier, op. cit. supta note 20, at 37. For "nausea" see L'Etre et Le NÉANt 399 (Beino and Nothingness 338-399); and Sartre's novel La Nausée (1938). And see W. Desan, The Traotc Finale 80, 183 (rev. ed., 1960); and Mounier, op. cit. 14, 30, 72, 122.

${ }_{75}$ For his analysis of these and other modes of inauthenticity see SEIN UND ZEIT 126-130, 167-180 (Beino and Trme 163-168, 210-224). 
This second, authentic mode of human existence is what Jaspers calls Existenz.76 For Heidegger, it is "ex-sistence," "standing outside oneself." He maintains that the ability to think about oneself, to stand outside oneself and observe oneself as if with external eyes, is given only to man. Accordingly man is the only existent: "God is, but he does not exist."77 For Sartre, this authentic mode of human existence becomes "l'être-pour-soi."78

Nevertheless, it is within this same framework that the difference between Jaspers and Heidegger on the one hand and Sartre on the other is most starkly revealed. For Jaspers, in his own personal sense, ${ }^{79}$ and for Heidegger also, in his still more personal sense, the movement from "being-there" to "Existence" is a movement towards God: towards the fullness or plenitude ${ }^{80}$ of Being-itself; the Transcendent; the ultimate universal mystical Being of everything that is. Neither of them can say much about this Transcendence that man moves towards or partakes of : 81 Heidegger tries to do so, tries to fathom Being-itself, but passes beyond comprehension; and Jaspers tells us that the presence of the Transcendent is "the silence in the face of Being." In this presence, "speech ceases": if we try to objectify it, we can no longer sense it even inarticulately.

This ultimate can be attained only in the transcending of all thought. It cannot itself be transcended. . . . Here thought must dissolve into radiance. Where there is no further question, there is also no answer. In the philosophical transcending of question and answer we arrive at the limit, at the stillness of being. ${ }^{82}$

76 See, e.g., Von der Wagrhert 76: Existenz is "the axis around which all I am, and all that can become truly meaningful for me in the world turns." And see Hoffman's essay cited supra note 26 , at $99-100$.

77 See Martin Hemegoer, Introduction to Was ist Metaphysik? (5th printing, 1949); and English translation by Walter Kaufmann in op. cit supra note 20, 206 at 214.

${ }^{78}$ See L'Etre et le Néant $115 \mathrm{ff}$. (Beino and Nothinoness $73 \mathrm{ff}$.); and for "l'etre-ensoi"' see L'Etre et le Néant 30-34 (Being and Nothingness biv-lxix).

79 See, e.g., Kart Jaspers, Existenzphilosophie 17 (1938).

80 Hoffmann, essay cited supra note 33, at 103, speaks of "sumptuousness" here.

81 See Karl Jaspers, The Perennial Scope op Philosophy 12 (trans. by R. Manheim, 1949), where he says that Transcendence is "the being of which one aspect of our essence constitutes an infinitesimal part." And see H. Kunz, essay cited supra note 47, passim; and on the jurisprudential implications of this union of Transcendence and Existenz see Hommzs, op. cit. supra note 13, and the discussion in G. E. Langemeijer, Bemerkungen zum Thema: Jaspers, das Recht und die Gerechtigkeit, 50 ARCHrv Für Rechrs- UND SozIALPHILOSOPHIE 169 (1964).

82 Einführuno in die Philosophie 47 (Way to Wisdom 49). Cf. Kaufmann, essay cited supra note 55, at 217. Insofar as Jaspers nevertheless attempts to articulate "Transcendence," he too passes into mysticism. See, e.g., VON DER WAHRHzIT 109: Transcendence is "the Encompassing as such, the Encompassing of every Encompassing. . . . Compared with general Transcendence belonging to each mode of the Encompassing, this Transcendence is the Transcendence of all Transcendence" (sic). And see R. D. KNudsen, The Idea of Transcendence in the Philosophy of KarL Jaspers (1958); and other citations supra note 70 . 
But it is quite clear that whatever they mean by the Transcendent, or Being-itself, both Heidegger and Jaspers would regard it as an incredibly rich, incredibly full state of Being; and the movement from man's inauthentic existence to his authentic Existenz is a movement towards and into a fuller state of Being because it is towards (though it can never reach) the ultimate fullness of Being. For Sartre, however, the fullness of Being is in the inauthentic mode of human existence, being-in-itself. This is a massive, heavy, "doughy," stupid form of brute factual being, "meaningless to itself, huge, ingenuous, too solid." This "doughiness" is the fullness of being, and it is a dead sort of fullness. Accordingly, for Sartre, the progression from inauthentic "being-in-itself" to authentic "being-for-itself" must be a movement away from fullness; and that can only mean, into emptiness. It must be away from being and into nothingness. This is only possible if we develop a crack in the fullness of Being, through which nothingness worms its way in. ${ }^{83}$

This divergence on the nature of authentic human existence is easy to exaggerate. But it does point us to the fact that each existentialist in his description of authentic existence is reading into what he describes his own value judgments about the kind of transcendence of "thingness" that man ought to be striving for. This in turn points us to the sixth and last of the preliminary points that I have set down for discussion: namely, that "authenticity" in the existentialist writings is a prescriptive value concept. It is, in fact, the core (and probably the sole substance) of the existentialist ethics: ${ }^{84}$ and since it is as an ethical philosophy that existentialism is prima facie most likely to be of legal significance, it may be worthwhile to examine some of the problems that such a value standard involves.

The central problem, of course, is that we have not traditionally been accustomed to thinking of "authenticity" as a value concept at all. Nevertheless something like a valuational use of the word can be detected under the surface, or around the edges, of our conventional usage. To clarify the situation we need to distinguish four possible meanings of the judgment that something is "authentic." In the first two meanings, an entity will be said to be "authentic" if it is "the genuine article," if it really is the kind of thing that it purports to be. But here already there is a possible ambiguity: thus far an entity might be authentic either if it really has the qualities and proper-

${ }^{83}$ Cf. Mounier, op. cit. supra note 20 , at $30-31$, summarizing L'ETre ET LE NÉANT 119-121 (Beino and Time 77-79). And see infra p. 111.

84 See Grene, article cited supra note 63. And cf. infra pp. 134-136, and the powerful discussion by Maritain in his 1964 work cited supra note 19, at $382 \mathrm{ff}$. My own analysis of "authenticity" hereunder was stimulated by a valuable unpublished critique of the notion by Lyndel V. Prott, Human Survival and the Concept of Authenticity (mimeographed, Australian Sockety of Legal Philosophy, July 9, 1964). 
ties that it appears to have, or if the qualities and properties which it in fact has are those which such an entity does in fact have. The former of these meanings we may call "the authenticity. of appearance"; the latter we may call "the authenticity of fact." If we see a man behaving like a gorilla we may be concerned to point out that he is not an authentic gorilla, and this would be "authenticity of appearance." But we might conceivably also want to say that he was not an authentic man; and this, so far as it was offered as a factual and not as a normative judgment, could only refer to "authenticity of fact."

In a third meaning, an entity will be said to be "authentic" if it really does have the origins that it purports to have: an oil painting is an "authentic Rembrandt" if it really is painted by Rembrandt (even if it is a poor example of his work). We may call this "the authenticity of origin." Finally, an entity will be said to be "authentic" if its qualities and properties are those that it is fitting or proper or desirable for such an entity to have. This may be called "the authenticity of fittingness."

Almost all current usages of the word "authentic" and its derivatives involve references to "the authenticity of origin." When we inquire into the authenticity of documents, of literary texts, and of works of art, the genuine origin of the item we are examining is all that is in question. Questions about "authentic antiques" are in the same category, though the reference here is to a temporal and not to a personal origin, and there may here appear to be some shading of reference to "authenticity of appearance," and perhaps also to "authenticity of fact." An "authentic gypsy" may have "authenticity of appearance" (as when we are concerned to point out that the swarthy man in spangles and beads really is what he appears to be), or "authenticity of origin" (as when we say that not the man in spangles and beads, but the man in the lounge suit, is "the authentic gypsy"), or "authenticity of fittingness" (as when other gypsies tell us disapprovingly that the man in the lounge suit is "not an authentic gypsy"), or even "authenticity of fact" (as when a cultural anthropologist tells us this last). Finally, while an "authentic Gregorian chant" seems clearly to involve an appeal to "authenticity of origin," "authentic jazz" is harder to classify. Is this jazz that stems from the classic New Orleans period ("authenticity of origin"); or any popular music in which the jazz elements are an intrinsic part of the creative act and not merely superficial imitations appended to an orthodox composition ("authenticity of appearance"), or any jazz which is true to the "essence" of jazz ("authenticity of fact"), or any jazz that exemplifies what is best in jazz ("authenticity of fittingness")? 
This kind of problem shows us that in fact our four kinds of authenticity are quite closely linked. "Authenticity of appearance" is very difficult to keep distinct from "authenticity of fact." (Consider, for example, a historical movie spectacular which has on the one hand "authentic settings" and on the other hand "authentic medieval costumes.") "Authenticity of origin" will always tend to shade over into "authenticity of appearance," of which, indeed, it is probably merely a special case. "Authenticity of fittingness" will in practice be very closely associated with "authenticity of fact." (Consider Lon Fuller's well-known point that the question "Is this a steam engine?" in practice "overlaps mightily" with the question "Is this a good steam engine?") ${ }^{85}$ Finally, "authenticity of appearance" and "authenticity of fact" share the common feature that both claim a merely factual significance, and will be used only in cognitive judgments; whereas both "authenticity of origin" and "authenticity of fittingness" have an obvious evaluative significance.

The existentialist use of the concept of "authenticity" depends on an impressionistic slurring-about amongst all four of these meanings, and on the inherent ambiguity of the whole cluster of meanings. Because the cluster is not well developed in our ordinary English usage, we may feel inclined to intolerance of this creative ambiguity. But intolerance should be tempered, first, by the fact that our word "authentic" is here only a translation of the German "eigentlich," which lends itself much more readily to the whole cluster of ambiguities; ${ }^{86}$ and second, by the fact that we have long tolerated in legal philosophy an exactly parallel cluster of ambiguities in relation to the word "validity." A "valid law" may be any lawlike rule which in fact on investigation turns out to be a law; or it may be, quite simply, any law; or it may be any law which proceeds from a competent lawmaking authority; or it may be any law which is in accordance with the moral purposes of law.87 And a great deal of jurisprudential writing has turned on the play between these meanings.

85 LoN L. Fulter, The Law in Quest of Itself 11 (1940).

86 A closer parallel might be found in the English word "proper" and its derivatives. When a boy grows up into an adult man we can say that he is now "a proper man" (properness of appearance), or that he has developed characteristics and attributes which are "properties" of manhood, or are "proper" to manhood, or pertaining to "man proper" (properness of fact), or that these are "his own proper" characteristics and attributes, which he has "in his own proper person" (properness of origin), or that they are characteristics and attributes which it is "proper" or "appropriate" for a man to have (properness of fittingness). Some of these usages are now slightly archaic, but all of them remain acceptable. Of course, the further we delve into archaic usages, the more we can find support for the fourfold usage of "authenticity" itself.

${ }^{87}$ See the analysis in E. Garcia Máynez, El Problema Filosófico-Jurídico de la Validez del Derecho, in his Ensayos Frlosófico-Jurídicos 9-82 (1959); and English translation, The Philosophical-Juridical Problem of Validity of Law, in Latin-American Legal PhiLosopay 461-512 (20th Century Legal Philosophy Series, vol. 3, 1948). 
When the existentialist points to self-awareness, creative exercise of the free individual will, the sense of personal responsibility, and so forth, as the qualities of "authentic" human existence, what does he mean? Presumably he does mean that among all the entities which are, objectively speaking, "human," only those with the specified qualities are truly human (authenticity of appearance); but in this context this is the least important connotation of the term. More important, he means (as a factual conclusion from his analysis of the human personality) that in these qualities lies the "essence" of human personality, that the human being is one which has self-awareness and so forth (authenticity of fact). Also, and very importantly, these qualities are "authentic" (eigentlich) because they are the individual's "own" (eigen) qualities; they are the qualities of which each individual is his own author (authenticity of origin). And finally, these are the qualities which it is right and proper for a man to have (authenticity of fittingness).

If we concentrate for practical purposes on the second and fourth of these meanings, we can now see that the existentialist use of "authenticity" involves a kind of merger between "the authenticity of fact" and "the authenticity of fittingness"- - in other words, between the "is" and the "ought," or between facts and values. Whether "authenticity" is a concept within which this kind of merger becomes a valid or allowable philosophic technique is a problem that cannot here be explored. ${ }^{88}$ But one point that may be relevant to that problem should also be stressed here. This is that (as in part already seen) the idea of "authenticity" as such is a purely formal idea, an empty pigeonhole that we may fill with any content we choose. Whether we are concerned with "authenticity of fact" or "authenticity of fittingness," the content of "authenticity" in relation to any entity will be supplied by each observer's own beliefs about the characteristics which that entity has or ought to have. This means, on the one hand, that the mere offering of "authenticity"

88 The existentialists themselves do not even seem to be aware of this as a problem. Heidegger alone; though he elsewhere relies heavily on such semantic mergings and slurrings, seems to have been sensitive to this particular example, and to have made a determined attempt to avoid it. See, e.g., Sein und Zeit 12 (Berve and Trme 33). Prescriptive existentialism (he there seems to say), which is concerned with the "straightening out" of Dasein's "affairs," is "existentiell" philosophy; descriptive existentialism, which is concerned with "ontological structure . . . the analysis of what constitutes existence," is the true "existential" philosophy. Others may dabble in the "existentiell"; Heidegger's philosophy will be purely "existential." (I have adapted the existentiell/existential contrast, used by the translators of BEING AND TIME, to the interpretation in ALLEN, op. cit. supra note 37, at 23-24.) Yet even Heidegger, in this very work, tends to transgress at key points into "existentiell" implications. See SEIN UND ZeIt 249-267, esp. at 266 (BEIng AND Time 293-311, esp. at 311) ; and other passages cited supra note 75. And cf. on the disadvantages of Heidegger's attitude, W. Kluback and J. T. Wilde, Introduction to their translation of Heidegger's UBER "DIE LINIE" (1955) as THE Question op Beino (1959), at 13-17. 
as a value for human individuals cannot give any particular guidance to any particular individual, beyond telling him to be true to what he conceives to be his essential nature, whatever that may be. On the other hand, it means that insofar as the existentialists do inject content into human "authenticity" by laying down certain generalized prescriptions for what authentic human existence must be like (in terms of self-awareness, refusal to be bound by convention, and the like), they are simply reading into "authenticity" their own value judgments about what sort of experience the individual life ought to be. This in turn means, of course, that within certain limits the existentialist "versions" of authenticity can differ among themselves: for example, Jaspers' persistent stress on "Reason" is quite contrary to the spirit of many other existentialist writings. By the same token, we ourselves are entitled to accept "authenticity" as a value and yet pick and choose among the existentialist versions of it, or even reject them all and substitute our own.

Yet all this is so only within limits. For the "authenticity" that we are here concerned with is ex hypothesi that of the authentic individual, and it is to be not only an authenticity of fact and fittingness, but also an authenticity of origin, in the sense that the qualities we are looking for are to be rooted in the individual's "authorship." It is then probably true that the only generalizations we can make about an "authenticity" thus rooted must be precisely in the existentialist terms. Any other generalized prescriptions giving content to "authenticity" would themselves conflict with the basic prescription that each individual must freely create his own authenticity; and even the existentialist prescriptions escape this trap only insofar as the kind of content they supply (self-awareness, freedom of choice, acceptance of responsibility for one's choices, etc.) is such as not to reduce the individual's freedom to follow his own "authenticity of fact," but merely to tell us what kind of freedom this is. The logical necessity of thus leaving each individual's choice unfettered by our prescriptions, seems therefore to be one main limit on the kind of content with which "authenticity" can be endowed.

In practice, moreover, our choice of contents even for a particular individual will soon become further restricted. For "authenticity of fact" and "authenticity of fittingness" are "empty" concepts only so long as both are equally empty. The nonexistentialist, of course, will want to examine more closely the supposed identification of these two kinds of "authenticity." But assuming that we accept the identification, it follows that once we have found a content for "authenticity of fact," this must ipso facto give us the content of "authenticity of fittingness"; and once we have found a content for "authenticity of fittingness," the very fact that we call it "authenticity" 
implies that it must also be "authenticity of fact." Authenticity of fact and authenticity of fittingness mutually determine each other. ${ }^{89}$

This leads to a remarkable dilemma. On the one hand, the existentialist wants to say that I am what I make myself, what I choose to be. Until I choose, I am nothing. To the old riddle whether heredity or environment is the determinant of human personality, he would answer: Neither. Heredity has nothing to do with it: my self has no inborn "authenticity of fact." Environment may shape my personality, but only to the extent that I choose to let it do so. I can, if I choose, throw off the shackles of environment and become something other than what it would make me; or I can accept that I am what it makes me, but resent it and struggle against it so that $I$ am not really conditioned by it because I am never willingly so conditioned; or I can accept it gladly and devote myself consciously and deliberately to the task of being what it makes me; or, lastly, I can merely be what my environment makes me in a mood of passive acceptance, never making any conscious choice in the matter at all. ${ }^{90}$ On the other hand, existentialism also seems to say that these various possibilities are not really open at all. If I choose something other than myself, I choose falsely; the life I then try to live and the pattern into which I try to force myself can never really be mine at all. And the important thing in life is to be myself, to realize that I cannot always be what I would like to be, any more than I can always be what I am according to the picture that other people have of me. When I "choose myself," what am I choosing? If I have no self until I choose myself, my choice can only be of a picture of myself. It may be $m y$ picture, which I project upon myself; or it may be the picture which other people have of me, formulated from their observations and experiences of me. But each of these pictures is only a picture - or perhaps it might better be called a "myth." I can choose any one of these myths, either my own or someone else's; and in fact I must inevitably do this and spend my life trying to act out the myth as best I can. ${ }^{91}$ But to say (as existentialism does) that I must be myself, must surely mean that the myth I choose will be the right choice only if by some fairly improbable chance it happens to correspond with my reality. And if there is only one reality which is truly "my" reality, must

89 See A. R. Blackshield, Il Pensiero Umano e la "Condizione Umana" in Relazione al Diritto e ai Valori, 40 Rivista Internazionale di Filosofia del Diritto 465, at 479480 (1963); and infra pp. 125-32.

${ }^{90}$ But, says Sartre, in this last case my very failure to choose is itself a choice. See L'Existentialisme est un Humanisme 73 (Kaufmann, op. cit. supra note 20, at 305).

91 For the most detailed literary working out of the various complex possibilities that here open up, see Max Frisch's novel STILLER (1954); and English translation by Michael Bullock, I'm Not StiLler (1958). 
it not be my reality before I choose it? If my only proper choice is to be my authentic self, must not that authentic self precede my choice? ${ }^{92}$

In the terminology which I have here introduced, the point can be more shortly stated. To say that I have no self until by an act of absolute freedom I make myself what I choose to be, is to apply the existentialists' generalized authenticity of fittingness, which is also their authenticity of fact. But it is also to deny the possibility of rooting $m y$ authenticity of fittingness in $m y$ authenticity of fact. Conversely, to say that if I choose to be something other than myself, I choose falsely, is to apply on the level of each individual the authenticity of fact; but it is also to deny the feasibility of the generalized prescriptions of existentialist authenticity of fittingness. As long as authenticity of fact is what finally governs, the individual will be limited, in his existential choice, to a choice of what he already is.

Nor does there seem to be any way in which we can escape this ultimate dominance of authenticity of fact: the apparent escape routes always lead us back to where we started. To say that I really choose only a picture of myself may mean that in fact what each individual chooses is his authenticity of fittingness, as he sees it; but to say that this will still be the wrong choice unless myth corresponds to reality, means that even where the choice is thus in terms of individual authenticity of fittingness, what governs is still authenticity of fact. We may seem to escape if we keep scrupulously to the level of the existentialists' generalized authenticity of fittingness: we may apply not the concept of authenticity as such, but the particular content that existentialism puts into it. But so long as we stay on that level, we will be superimposing a generalized view of human "essence" on each individual's choice; and this will inauthentically fetter and collectivize his existence, unless the superimposed view is formal only, a pure "empty" authenticity which each individual is free to fill with his own authenticity of fact. We have seen that authenticity "as such" is such an empty concept; and that probably the kind of content that the existentialists give to it does leave it still (as it were) operationally empty. But this means that once we put the concept into operation, each individual can and must choose either his actual authenticity of fact, or at least his view of his authenticity of fittingness.

If he is sufficiently perceptive (and self-satisfied) to choose the former, then we are back again where we started. Moreover, by adhering to his own individual authenticity of fact, he will then fall into inauthentic being in

92 It is this question that raises the most crucial difficulties for the affirmation "Existence is prior to essence," discussed supra note 28. Arthur Kaufmann, in his 1963 article cited supra note 12, at 88-89, joins with the present writer in flat rejection of this formula on the above ground. And see Plattel, article cited supra note 57, at 21 ; and infra note 93. 
terms of the existentialists' generalized authenticity of fittingness. This seems to indicate that the "authentic" choice by this latter standard is that by which the individual chooses his view of his authenticity of fittingness, even if this is uncorrelated with his actual authenticity of fact. This, of course, would reduce "authenticity" solely to the existentialist version of it; we would be left with no authenticity concept "as such" - since if that concept is to have any significance in this context, apart from that of a mere shorthand expression which means self-awareness, responsibility, and so forth, then it must imply that authenticity of fittingness is rooted in authenticity of fact. Let us suppose, however, that the choice in question is indeed to be of an authenticity of fittingness which the individual creates by projecting it in the moment of choice itself. The existentialists can certainly accord to this projection authenticity of origin, in the sense that it is his projection. Can they also accord to it authenticity of fittingness in their sense, that is, in the sense that it is a new projection independent of any prior "authenticity of fact" operating to restrict his freedom?

Of course they cannot. Whatever the terms in which the individual thinks of his choice, he must have chosen something; and this something must already have been in him to choose. Even if the choice is of an authenticity of fittingness as distinct from and not rooted in authenticity of fact, it must have been guided by values, which again were already in him to serve as guides. ${ }^{93}$ Nor does it help to say that these values were merely the product of earlier creative projections. This leads simply to an infinite regress in which choices are based on past choices based on past choices, and so on. No doubt this might offer the most accurate picture available of how our value decisions and projections are actually made. Yet an infinite regress is hardly satisfying as the way out of a dilemma.

C. The "Mood" of Existentialism. - So much has been said and written about the distinctive emotional "mood" of existentialism that it seems important finally to point out that it has none. Above all, it is important to reject

${ }^{93}$ Cf. Grene, article cited supra note 63 , at 271 :

It is true that it is $I$ who have-always-already-chosen the values by which $I$ live. But I have chosen, not created them; if they were not in some sense there to be chosen, if they did not somehow compel me to choose them, they would not be values at all. . . . For Sartre ... either I myself, all alone, simply act or I enslave myself to a falsely hypostatized being; hence the desperate endeavour to make of the act itself ... the whole end and object of the free man. But there are no pure acts. An act involves a reference to values which in some way make a claim on the agent.

And cf. Maritayn 21964 work cited supra note 19, at 361: "It is because Kierkegaard is a Christian that at the end of his existential dialectic he finds himself face to face with God; an atheist, at the end of his existential dialectic, will find himself face to face with the void." 
the popular misconception of existentialism as the despairing product of a morbid preoccupation with meaninglessness and death - "as merely a philosophy of the cafés, a highly imaginative rationalization of human misery assuming the guise of sophistication."94 This popular image, as we have seen, arises largely from a mistaken identification of the literary personality of Jean-Paul Sartre with the nature of his philosophy, and of this with existentialism generally. It may be that Sartre's literary personality warrants the common estimate, and that even in the technical philosophical investigations of his L'Etre et le Néant, the point is frequently reached at which such discussions "cease to be the exploration of fundamental structures of human existence and begin to be an almost literary documentation of the experiential vagaries of [the] author."'95 But even these propositions are open to debate; and to erect them into sweeping statements about existentialism in general seems quite unjustifiable. Existentialism in general is simply "the exploration of fundamental structures of human existence."

There are, of course, at least three distinct ways in which death and despair, "fear and trembling," and "the sickness unto death" enter into the fabric of this general exploration. First, the existentialist rebellion against rationalist philosophical systems has the effect of restoring what Bochenski calls the "tychic element" in philosophy (the concern with man's lot or fortune) to a prominence that it has not had since the days of the pre-Socratics. (Heidegger in particular tends to see his whole philosophy as a return to the pre-Socratic roots of Western thought.) If "death, suffering, failure" are overemphasized in the writings that result, we can pardon this to some extent (as Bochenski is inclined to do) as a mere overreaction to their nineteenth century underemphasis, so that on balance what emerges is still a contribution to the overall "recuperation of our life and thought."96 Second, if we are looking for characteristic manifestations of private, personal, subjective experience, the malaises of this experience are at least one kind of datum that must be taken into account, simply on the level of dispassionate analysis. Third, they are a peculiarly significant kind of datum, both for the descriptive purposes of existentialism (articulating the meaning of Being)

\footnotetext{
94 Molina, op. cit. supra note 20, at 1 . This book is perhaps the most determined and cogent attempt to overcome such a misconception.

$95 \mathrm{Id}$. at 73 . Tiryakian's instinct (op. cit. supra note 29 , at 71 ) is therefore profoundly right when he refers to the main stream of thought as existentialism (i.e., without quotation marks), and the Sartrian version as "existentialism." Of course this device is neither formally satisfactory, nor substantively justifiable - just as I could not myseif really justify as a serious assertion my suggestion infra note 220 that Sartre should be seen as an "inauthentic" existentialist. But both the morbidity and the popularity of Sartre's ideas put them in a clearly different category from those of Jaspers, and even of Heidegger.

96 BochensKI, op. cit. supra note 16, at 198-199. See also Grene, article cited supra note 63 , at 268 .
} 
and for its prescriptive purposes (prodding man into individual authenticity). The prospect of death, for example, operates on the descriptive side to define one limit of human existence, and to set this existence against an inescapable nonexistence which gives it meaning not only by contrast, but by entering into existence as part of its reality. ${ }^{97}$ It operates on the prescriptive side by making the individual aware of his subjectivity and impermanence, by challenging him to accept the realities of his human situation and to react to them in a worthy human way. "It is in the face of death that each man stands most strikingly and irrevocably alone." 98

All this does not entirely refute the charge of pessimism and morbidity. Joy, too, is a uniquely human experience of individuals, just as intangible and subjective and yet just as vividly real as despair. Joy, rather more than despair, can give us a feeling of extendedness, of fuller reality, of participation in the Transcendence of Being. Yet we hear little of this kind of experience in existentialist writings. Joy is mentioned as a result of the ascent into authenticity, but not as a stepping-stone for the ascent. ${ }^{98}$ a Hope is mentioned only to be dismissed as analytically reducible to the same kind of existential experience as fear. ${ }^{99}$ Jaspers, it is true, gives us an existentialism of fortitude, patience, and courage; but it may well be that the existentialism of elation still has to be written. But the important point is that such an existentialism would still be existentialism. Both Kierkegaard and Sartre are obviously morbid, unhappy individuals; and it may well be that they have projected their personalities into their philosophies. Indeed, one of the important lessons existentialism seeks to teach is that all philosophies are projections of the personalities of the men who made them, and that the meaning of the philosophy must always be sought in the character of the man. ${ }^{100}$ On this basis Sartre's philosophy cannot fail to be one of morbid pessimism, Kierkegaard's of religious obsessiveness, Heidegger's of scholastic mysticism, and Jaspers' of verbose humanist solemnity. Yet we cannot expect

97 See Sein und Zeit 237-267 (Being and Time 281-311); Boghenski, op. cit. supra note 16, at 167; AlleN, op. cit. supra note 37 , at 35-36.

88 Grene, article cited supra note 63 , at 268.

98a Sein und Zeit 310 (Being and Time 358).

99 Sein und Zeit 345 (Being and Trme 395-396).

100 Cf. Molina, op. cit. supra note 20 , at 76 , pointing out that on the existentialist premises Sartre's philosophy, for instance, "not only can but should reflect the morbidity of Sartre's existence if it is a fact that his existence is morbid." And see supra note 93. The point is not that our experiences shape us and therefore indirectly shape our ideas, but that we "pro-ject" our ideas out of ourselves. The former kind of point would seek to "explain" Austin's legal philosophy, for instance, by reference merely to his experience in the army (cf. Fuller, op. cit. supra note 85, at 106); the latter would stress rather that Austin first approached his study of law with the "pro-ject" already formed in his mind of working "not only to qualify himself as a special pleader, but to study and elucidate the principles of law." (Cf. Stone, op. cit. supra note 2, at 63n.-64n.) 
any one of these characterizations to capture the nature of the "existentialism" which is common to all of these.

In any case, it is all too easy to overgeneralize in these intangible matters of philosophical mood. For instance, I shall here tend to depict Sartre as par excellence the pessimist of existentialism, and Jaspers as its optimist. Yet Sartre too can be challenging and inspiring; ${ }^{101}$ and Jaspers can be pessimistic and depressing. Their respective attitudes to free will - a central concern of all existentialists - afford a good illustration. Sartre, having stripped human personality of practically every content except freedom of will, strains rather disconcertingly to make this freedom limitless. But for Jaspers, freedom must always be unfolded through struggle and opposition, and must consequently always be limited. Absolute freedom could pertain only to a totality which met no opposition because it contained all oppositions within itself. Freedom becomes empty without contradiction; "absolute" freedom is absolute nonsense. 102 And he stresses the existence of "limit-situations," before which all our human potentialities come to a full stop.

Among the "limit-situations" which Jaspers enumerates (I must die, I must suffer, I must struggle, I am subject to chance), there are at least two of special interest in moral and in legal philosophy. The first, irremediable injustice, will be examined later; the second, inexorable guilt, may be briefly. explained now. He maintains, not only that any action which I "freely" perform (in the sense that it need not occur and could also occur differently) may involve me in guilt; but that in addition, and in a larger sense, existence itself is guilt.

I am responsible for all the evil that is perpetrated in the world, unless I have done what I could to prevent it, even to the extent of sacrificing my life. I am guilty because I am alive and can continue to live while this is happening. Thus criminal complicity takes hold of everyone for everything that happens. ${ }^{103}$

The point is not that Sartre, whose "mood" is one of morbidity, can also sometimes speak with passionate challenge; or that Jaspers, whose "mood" is one of aspiration, can speak with uncompromising grimness. It is rather that Sartre's challenge arises out of his despair, and Jaspers' bleakness out

\footnotetext{
${ }^{201}$ See his 1946 lecture cited supra note 28; and see BARRETr, op. cit. supra note 20, at $213 \mathrm{ff}$.

102 Cf. Karl Jaspers, Philosophie 465 (2nd ed. in one volume, 1948): "Freedom in its realization is never complete; in its most decisive effort at realization, freedom is, rather, confronted by itself as the most abysmal lack: I am real, but neither fulfilled, nor close to possible fulfilment." And see generally Ricoeur, essay cited supra note 70, at 632-639.

103 VoN dRR Wagrheit 932 (Tragedy is Not Enovgh 53-55).
} 
of his ideals; or, more precisely still, that in existentialism despair and challenge, high ideals, and hopelessness, are paradoxically one. Jaspers' "limitsituations" themselves can neither be changed nor surmounted, but only acknowledged and faced with steadfast fortitude and courage. But this last possibility - man's ultimate potentiality - gives meaning alike to the limitsituations and to the freedom of Existenz.104 The "mood" of this outfacing of unfaceable limits is one of neither faith nor despair, but a coming together of both. And if such a blend seems perilously insecure, that very insecurity is what existentialism is basically concerned to express.

\section{Law, Social Control, and Justice: An Existential Re-view}

A. Existentialism and "the System." - The rationalizing, systematizing, conceptualizing way of thought which Kierkegaard so passionately opposed in philosophy and theology has thrust itself in recurring manifestations into legal thinking as well. ${ }^{105}$ Indeed, it may even find a peculiar foothold in legal thinking. For law is an attempt to impose order and regularity on the hurly-burly of human affairs; ${ }^{106}$ and it therefore lends itself with particular readiness to the assumption that it is itself an orderly sort of phenomenon, that the interconnections between its parts tend to be of a logically consistent kind, and that the whole legal order therefore tends towards one systematic unity. ${ }^{107} \mathrm{~A}$ certain amount of system-building in analytical jurisprudence may be justified simply as an attempt to spell out explicitly the implications of this assumption: to provide us with a clear understanding of what it is that the law is thus assumed to tend toward, of what the law would be like if it really were a system, of the respects in which the actual law falls short of this system, and of the ways in which these shortfalls might be minimized or overcome. ${ }^{108}$

When, however, we are told that law is a rigorously ordered system; that all acts of legal cognition must make use of this system; that we need no "impure" descriptive or normative orientation to the real-life problems of law, but only the epistemological orientation that is given by the system; that the system is not only nor even primarily a picture of the logical relations of legal norms in a state of rest, but rather of the dynamics of their

104 VON DER WAHRheit 946 (TRAGedY is Not ENovgh 77).

105 Cf. Fuller, op. cit. supra note 85, at 81, on the parallel between "theoretical theology" and "analytical jurisprudence." And ef. Judith N. ShkLar, Legnlism (1964).

106 See Edoar Bodenheimer, Jurisprudence: The Philosophy and Method of the LAW 161-175 (1962); Blackshield, article cited supra note 89, at 469 and passim.

107 See Stonz, op. cit. supra note 2 , at 44.

108 See id. at 41-55, 65-68, 87-92, 210-211. 
creation; and that although the system rests on a hypothesis, the system itself is self-sufficient and complete - then we are in the presence of an archsystematizer in whose hands "the System" assumes proportions and pretensions comparable to those which led Kierkegaard to his violent indictment of Hegel. It is therefore perhaps not surprising that much of this 120-year-old indictment might almost be reprinted verbatim, under the new heading: "Kierkegaard $v$. Kelsen."

The indictment begins with some rather heavy irony about the failure of the system-builder to complete his system, culminating in the sharp point that "System and finality are pretty much one and the same, so much so that if the system is not finished, there is no system. . . . A system which is not quite finished is a hypothesis." 100 Then the system-builder is confronted directly, man to man - assuming, that is, that he will accept this level of interrogation ("If he presumes to be speculative philosophy in the abstract, pure speculative thought, I must renounce the effort to speak with him; for in that case he instantly vanishes from my sight, and from the feeble sight of every mortal").110 Thus confronting his adversary, Kierkegaard concedes that "a logical system is possible," but only so long as it observes the limitations of logic. "Nothing must . . . be incorporated in a logical system that has any relation to existence, that is not indifferent to existence"; and the price which the logical system must pay for this indifference to existence is that it can never be more than a hypothesis. ${ }^{111}$ The sin of Hegel's system (and of Kelsen's) is twofold: it claims to be absolutely valid and not merely hypothetical, and it seeks to accommodate the dynamics of real-life movement and change within its systematic structure. "The introduction of movement into logic, is a sheer confusion of logical science. . . . Surely it is strange to make movement fundamental in a sphere where movement is unthinkable; and to make movement explain logic, when as a matter of fact logic cannot explain movement."112 The point is that although a logical system is possible,

An existential system is impossible. . . . Does this mean that no such system exists? By no means; nor is this implied in our assertion. Existence itself is a system - for God; but it cannot be a system for any existing spirit. System and finality correspond to one another, but existence is precisely the opposite of finality. . . . System and existence are incapable of being thought together; because in order to think existence at all, systematic thought must think it as abrogated, and hence as not

103 Concluding Unscientific Postscript 92 (The Search for Being 53-54).

110 Concluding Unscientific Postscript 93 (The Search for Beino 54).

111 Concluding Unscientific Postscript 93-94 (The SeArch por Beino 54-55).

112 Ibid. 
existing. Existence separates and holds the various moments of existence discretely apart; systematic thought consists of the finality which brings them together. ${ }^{113}$

The Kelsenite jurisprudential system, therefore, with its "dynamic" hierarchization of the creation of legal norms, must crumble absolutely under an existentialist view of legal philosophy. Its formal, intellectual patterning of the law is a world removed from the contingent, discontinuous, organic reality of law as it is in life; and the attempt to build the dynamics of law creation into the pattern succeeds only in destroying such intrinsic validity on its own level as the system might otherwise have had.

For the more usual non-Kelsenite variety of analytical system, however, the implications of the existentialist attack are more ambiguous. For the writer engaged in constructing this kind of system does work in terms of genuinely logical and not "dynamic" interrelations of its parts; and so long as his results are presented as a mere hypothetical system, as a model of what a logical legal order might be like, ${ }^{114}$ existentialism seems likely to tolerate his activities - not, indeed, to concede that they have any particular value, but at least to allow him to

sit in the barn

And keep himself warm

And tuck his head under his wing, poor thing.

If, however, he brings his head out from under his wing and attempts to apply his system to actual law, or to fit actual law into his system, then again the existentialist will object. For here again the logical absoluteness of the system will be encroaching upon the existential contingency of "the life of the law."

Yet this is not the end of the matter, for either type of analytical system. Thus far, the implications of the existentialist hostility to "systems" amount merely to support from an unexpected quarter for the lessons about the limitations of logic in the law which have been preached to us for years by growing numbers of jurisprudents, whether nominate "legal realists" or not. Yet neither in these familiar versions nor in the existentialist reprise should such lessons be taken necessarily to mean that logical systems are simply to be discarded. The logical systems are there, just as much as the diffuse richness of the case law; and the proper way of dealing with them

113 Concluding Unscientific Postscript 93, 101 (The Search por Being 54, 60).

114 Cf. John Austin's statement of his aims in the letter quoted by Sarah Austin in her preface to Austin, 1 Lectures on Jurisprudence 17 (5th ed., 1885). 
is neither to adopt them exclusively nor to rule them out of consideration, but to try to understand them in relation to every other aspect of the legal situation, to see what they can really mean and of what use they can be. They are not a way of completely representing law, but they are one inescapable part of the way we think about law - inescapable, moreover, because in any event they represent our response to something that is there in the reality of law. We cannot escape our own felt need to organize and systematize the phenomena we have to deal with, whether in the law or in any other field of endeavor. Nor (Heidegger at least would add) can we escape the demand which the phenomena themselves make upon us for systematic reading and understanding:

Our whole existence is challenged everywhere - now as in play, now urgently; now as if set upon, now as if pushed - to plan and calculate everything. What does this challenge mean? Is it merely the product of man's self-generated mood? Or are we actually concerned with Existence itself in the sense that it makes a claim upon us with respect to its schematization and calculability?115

We must not, then, deny all validity to our analytical "systems." They do have a certain validity, as projections which the human being must make when he thinks about reality, and which are in some sense true for him; or as "symbols" or "ciphers" or metaphors through which the human being expresses in an incomplete and distorted way truths immanent in reality which he could otherwise not express at all. Yet what we must not do, either, is to suppose that the systems which we are thus led to construct are in any sense absolute. We must never forget (in Heidegger's terms again) that they are our "pro-jects," and have no more validity than we give them; and if we cannot think without systematizing anyhow, ${ }^{116}$ it may be better to throw the conscious emphasis onto the "anti-system" limb of this system/anti-system polarity.

All this is borne out by the philosophical experience of the existentialists themselves. All of them in fact construct "systems" of thought around a coordination of key concepts. Sartre in particular offers a highly finished and complex philosophical "system." The least systematized existentialist philosophy is that of Jaspers, and even he has been criticized for his oversystematizing, or at least for the arbitrariness of the elements of "system" that

115 Identität und Difperenz 26-27 (Essays in Metaphysics 25).

116 Cf. Knauss, essay cited supra note 71, at 175: "The path to.ever further formalization seems to be the path of thinking itself." And see generally on this matter Blackshield, article cited supra note 89. 
his work contains.117 What the existentialist adds to his systems is a radical distrust of systems, a profound realization (at least in Jaspers' case) that even what he himself offers as "system" can never attain truth. Like Wittgenstein in the Tractatus Logico-Philosophicus, 11s the thoroughgoing existentialist must finally deny the validity even of his own propositions. Kierkegaard's "alone over 70,000 fathoms," offered as a graphic cry expressing the loneliness of the individual existent before his God, becomes for Jaspers a statement of the final "shipwreck" of the philosopher.

At the end we have no firm ground under us, no principle to hold on to, but a suspension of thought in infinite space - without shelter in conceptual systems, without refuge in firm knowledge or faith. And even this suspended, floating structure of thought is only one metaphor of Being among others. ${ }^{119}$

Yet this still leaves us with the tertium quid of an "open" system, or - as Jaspers terms his own work - an "offenhaltende Systematik"; and with this, it seems, we must finally be content, in law ${ }^{120}$ as in philosophy itself.

Thus far, the existentialist attitudes and arguments are, I believe, directly relevant to analytical jurisprudence. The systematizing drive of the human intellect is the same phenomenon, whether it manifests itself in philosophy, theology, legal theory, or (for that matter) social science. An emphasis within any discipline on the ultimate untenability of systems is therefore salutary for all disciplines. When this is coupled with emphasis on a certain metaphorical relationship between system and reality, and in any event on the indispensability of systems as a part of our human techniques for relating our own cognitive activities to reality, the result is to point us towards an attitude to systematic theories which is potentially more realistic and more genuinely constructive than any we have yet had. Admittedly, it is an attitude which we might arrive at independently of existentialism: for instance by starting from the modern philosophy of science, ${ }^{121}$ or from relativism generally, ${ }^{122}$ or from the grappling of Talcott Parsons and other

\footnotetext{
${ }^{117}$ Knauss, essay cited supra note 71 , at $171 \mathrm{ff}$. But cf. Hoffman, essay cited supra note 33 ; and see Knauss's own final admission quoted supra note 116.

118 Ludwio Wittgenstein, Tractatus Logico-Philosophicus 189 (proposition 6.54) (1922): "My propositions are elucidatory in this way: he who understands me finally recognizes them as senseless, when he has climbed out through them, on them, over them. (He must so to speak throw away the ladder, after he has climbed up on it.)"

119 VON DER WAHRHEIT 185-186.

120 Cf. Theodor Viehweg, Topik Und Jurisprudenz (1953).

121 See, e.g., the concept of "paradigms" developed by T. S. KunN, The STructure or Scientific Revolutions (1963); and discussed by several contributors to the colloquium Scientific Ghanoe (ed. by A. C. Crombie, 1963).

122 See Stone, op. cit. supra note 1, at 227-232, esp. 228.
} 
sociologists with the proper status of "higher-order theory" in sociology, ${ }^{123}$ or even from the spreading interpretation of Kelsenism as an artificially tidy "rational reconstruction" of the actual legal order.124 But the attitude on which all these lines of thought thus tend to converge is one which all of them at the present stage of contemporary thought are still groping to articulate, and at such a stage all pointers towards it must be of real value.

This, then, is a direct contribution that existentialism can make to analytical jurisprudence. Beyond this, however, the concerns of the legal analysts are directed to specifically juristic problems of a kind in which existentialism is simply not interested. It follows that any additional contribution that existentialism can make to legal analysis must be only in terms of what I have earlier described as the borrowing of symbols or ciphers; that is, the existentialist concepts and intellectual constructions will be of significance in juristic analysis only to the extent that they offer metaphors or analogies for the more vivid expression of what we ourselves seek to say.

Such borrowings must obviously be used with great caution. Legal philosophy is still struggling with the confusions caused by the pre-Socratic philosophers' indiscriminate transference of ideas from ethics and politics to cosmology and back again ${ }^{125}$ the effects of the first enthusiastic use of Darwinist and Freudian concepts in legal and social philosophy are only now being overcome; and contemporary sociology is still in the throes of a similar misleading romance with the technical concepts of economics. ${ }^{126}$ But in all these cases the trouble seems to lie not so much in the use of another discipline's concepts as in the lack of sufficient awareness that in their new field of application the force of such borrowed concepts could only be metaphorical. If this is so, we can safely search existentialism for useful metaphors and analogies, so long as we remain sharply aware that in our field this is all they can be.

Although I have denied that these caveats extend to the general use I

123 See Talcott Parsons, The Socinl System (1951); Talcott Parsons, An Outline of the Social System, in 1 Treorizs op Society 30-79, esp. at 32-33 (ed. by T. Parsons, E. Shils, K. D. Naegele, and J. R. Pitts, 1961).

124 See M. P. Golding, Kelsen and the Concept of "Legal System," 47 ARcriv für Rechts- Und Sozialphilosophie 355 (1961) ; H. L. A. Hart, Kelsen Visited, 10 U.C.L.A. LAw Review 709, 710-717 (1963).

125 See Stone, op. cit. supra note 1, at 11, and other works there cited; Dennis Lloyd, The Idea of Law 70-74 (Pelican Books, 1964); and Jerome Frank, Courts on Trial 352 (1949).

${ }^{126}$ For a striking illustration see Paul Diesing, Reason in Society (1962), which was written for the express purpose of breaking up a supposedly widespread modern tendency to see "reason" solely in terms of one type of rationality, namely "economic rationality"; and is itself, in language, attitudes, and methods of analysis, almost constantly subject to the vice it seeks to eradicate. Many aspects of Talcott Parsons' work are of course open to similar criticism. 
have attempted to make of the existentialist attack on "systems," I must of course admit that they apply with some force to my particular parallel between Kelsen and (Kierkegaard's) Hegel. Nevertheless, I now want to press this parallel even further. For although, in relation to the source or startingpoint of the system, the parallel between Kelsen's system and the kind that Kierkegaard is attacking seems to break down altogether, nevertheless Kierkegaard's statement of his attack offers not only a critique which we can metaphorically apply to Kelsen, but at the same time a device by which Kelsen's theory might metaphorically be saved.

Kelsen's system, of course, begins from a "basic norm," a "legal-theoretical presupposition,"127 a "hypothetical norm which actually128 does not stand inside the systems of positive norms but first of all founds these systems; it is not an enacted norm but a presupposed norm."129 What Kierkegaard is attacking is by contrast a system which, "so it is said, begins with the immediate, and hence without any presuppositions, and hence absolutely; the beginning of the System is an absolute beginning."130 Yet when Kierkegaard argues that this beginning with the immediate can at any rate not be done immediately, but only as an ex post facto result of a process of reflection upon existence, and that in reality "no logical system may boast of an absolute beginning, since such a beginning, like pure being, is a pure chimera,"131 he seems to be invoking arguments which are equally applicable to Kelsen's use of the Grundnorm as basing a "pure" theory of law.132 With still more significance, when he goes on to give his explanation of how the Hegelian system really begins, he seems to offer a more explicit and more comprehensible version of Kelsen's own "hypothetical" solution.

In order for the system to begin, says Kierkegaard, the preliminary process of reflection on existence must first be halted. What is required to put an end to reflection is a resolve:

... for in no other way can the process of reflection be halted. . .

127 Hans Kelsen, Allgemeine Stantslegre 126 (1925).

128 The word used is "eigentlich." It would of course be fanciful to translate this as "authentically," and to attempt to solve the difficulties of Kelsen's presentation by saying that Kelsen actually intends to speak of one mode of being of the basic norm in which it is merely "present-at-hand" as part of the everyday legal system, and a separate, higher, and "authentic" mode of being in which the basic norm is outside the legal system. But we shall presently suggest that something like this may be the most useful way for us to make sense in our own minds of what Kelsen has tried to say. In particular, this would enable us to sort out our own understanding of the problems raised by Julius Stone, Mystery and Mystique in the Basic Norm, 26 Modern Law Review 34 (1963), which in Kelsen's own terms seem quite intractable.

129 Op. cit. supra note 127 , at 104 ; and cf. id. 249.

130 Concludino Unscientific Postscript 95 (The Seargh por Beino 55).

131 Concluding Unscientipic Postscript 96 (The Search for Being 56).

132 See Stone, op. cit. supra note 2, at 127-131. 
A philosopher is never justified ... in ... asserting . . . that the reflective process halts itself and comes to an end in an absolute beginning. . . . If a resolution of the will is required to end the preliminary process of reflection, the presuppositionless character of the System is renounced. Only when reflection comes to a halt can a beginning be made, and reflection can be halted only by something else, and this something else is something quite different from the logical, being a resolution of the will. ... What if, instead of talking or dreaming about an absolute beginning, we talked about a leap? ${ }^{233}$

By introducing the concept of a "leap" at this point, Kierkegaard is himself borrowing a metaphor from another part of his work. It is by a "bounding-leap," he has elsewhere said, ${ }^{134}$ that the human being confronted with a realm of possibility enters into his authentic existence - not by any orderly rational growth, but by a sudden flash of commitment. In his present philosophic universe of discourse the figure is equally appropriate; and in our own juristic universe of discourse it may be a more satisfactory way of expressing how the basic norm "comes about" than any Kelsen himself has hitherto devised. In the Kelsenite framework, the idea that the basic norm is not derived, as all other norms are derived from it, but must be postulated, is an uncomfortable idea which Kelsen has never made finally and fully comprehensible; but in Kierkegaard's universe of discourse it is perfectly at home as an example of the creative bounding-leap of the human being.

This "bounding-leap" lives on into the philosophy of Heidegger, who elaborates on the concept. The leap is a leap into Being, into what we might here call "superbeing"; it is the revelation of a state of superbeing in the midst of being. It is a movement towards, and an expression of, Being itself. This may seem to mean that we cannot, after all, identify the basic norm of a legal system with the product of this leap. Clearly, in any case, an existentialist would regard such legal theorizing as quite irrelevant and inappropriate in this context. To express the movement, revelation, or expression of "Being" in normative form at all, would at best express only a trivial part of its fullness and transcendence; and even if we did manage to isolate in such a formulation the normative aspect of Being, the norm we produced would still partake of fullness and transcendence to such an extent that to express a further distillation from this as the basic norm of a legal order would still be to express only a trivial part of this "real," this "transcendent" basic norm. Conversely, on Kelsen's side, he would hardly be likely to admit any relevance of Heidegger's leap into "superbeing," to the concerns of "legal

133 Concludino Unscientific Postscript 97, 98 (The Search for Beino 57, 58).

134 See supra note 39. 
science." Nevertheless, if we can see our way through this prima facie inappropriateness, we may find a revealing clue to the tacit metaphysical mysticism that underlies Kelsen's "world of law" and his "pure legal ought."

It would still be true that a legal basic norm arrived at by the above kind of articulation out of the fullness of Being would seem trivial and inadequate to a Heidegger. But a Jaspers might well be prepared to accept such a humanly formulated norm, as a typically inadequate human "symbol" or "cipher" of something which is present in the higher realms of Being in the Transcendent, or the Encompassing, or Being-itself. Such a basic norm would be arrived at, not indeed by deduction from a formulation of the Encompassing, but by focusing in our formulation on one aspect of the Encompassing, which of course can never be exhausted in any formulation. A promising starting-place might be found, for example, in "the Law of the Day" (Gesetz des Tages) which Jaspers opposes to "the Passion for the Night" (Leidenschaft zur Nacht), thereby stating a polarity in the midst of which he sees human Existenz as perpetually suspended, pulled now one way and now another, but always authentically in the former direction.

The Law of the Day orders our existence, demands clarity, consistence and loyalty, binds us to reason and idea, to the one and to ourselves. It demands actualization in the world, that we build within time, that we complete our existence on an endless road. . . . The Passion for the Night breaks through every order. . . . It is the urge to ruin oneself in the world in order to complete oneself in the depth of worldlessness. ${ }^{135}$

Kelsen himself might not be too unwilling to recognize "the Law of the Day" as a kind of basic norm of basic norms. But whether we choose to approach our search for the basic norm through this or some other ciphered aspect of the Encompassing, the important point is that to search for the basic norm in the Encompassing at all will lead us to see our statement of it as an imperfect human formulation of some sort of pure quintessence of absolute legal oughtness which is inherent in Being itself. We may call this supposed quintessence of oughtness "the Transcendent Basic Norm."

To interpret Kelsenism as based on a Transcendent Basic Norm which we arrive at through a leap into Being would have some strange but interesting consequences. First, it would enable us at last to make sense of Kelsen's mystical references to "the world of law," by which he seems to mean that all positive legal systems are linked together in one vast monistic structure of pure legal oughtness. ${ }^{136}$ On the above interpretation we would in fact

135 Jaspers, Philosophie $762-763$ (edition cited supra note 102).

136 See Stone, op. cit. supta note 2, at 122, 130-131; S. I. Benn « R. S. Peters, Soctal Principles and the Democratic State 79-81 (1959). 
find ourselves talking in terms of three worlds of law, corresponding roughly to Jaspers' three modes of orientation to the World, the Self, and Being. "Law" in its world-orientation would consist simply of the earthy "lawstuff" of all actual legal norms - with the rider that all of these would be seen as empirical expressions and manifestations of the Transcendent Basic Norm, and that each of them would therefore hold within itself a tiny microcosmic manifestation of - or glimpse into - the pure legal oughtness of this Transcendent Basic Norm. "Law" in the mode corresponding to an ontological orientation to Being would consist of the total structure glimpsed by seeing all these microcosmic "bits" of pure oughtness in their overall relationship with the Transcendent Basic Norm, this whole totality constituting what Kelsen means by "the world of law." Finally, "Law" in the mode corresponding to the self-awareness of Existenz would consist of the systems "pro-jected" by analytical jurists; or perhaps simply of the activity of "projecting" these systems. We might refer to these three "modes of being" of law respectively as "actual law," "the oughtness of law," and "juristic law."

Second, this would enable us to see more clearly the issues in the continuing debate over possible "levels" on which Kelsen's pure theory is to operate, ${ }^{137}$ and in particular to restate the current interpretation of the theory as a "rational reconstruction" of law. On the above interpretation, most of the "systems" set forth by "juristic law" find their subject matter in "actual law." In such cases the system-builder himself may see his work as the description of a systematic structure which he conceives to be inherent in actual law; but from the existentialist viewpoint his work can only validly be seen as a "rational reconstruction" of actual law, or at best as a "projection" of certain tendencies that can be found in actual law. On the other hand a system-builder of unusual subtlety might find his subject matter not in "actual law" as such, but in "the oughtness of law." He, too, might want to see his work as the description of a systematic structure which he thinks he can see in "the oughtness of law"; but here, too, from our present viewpoint his activity would need to be restated. In existentialist terms, this kind of activity would have to be described as the construction of a set of symbols or ciphers which can only partially capture and partially convey "the oughtness of law" itself, rooted as this latter is in Transcendence. Finally, both these kinds of system-builder might want to project their systems onto "actual law" itself: to say that actual law is, or can be understood through, the

137 See esp. Hart, article cited supra note 124 , at $712 \mathrm{ff}$. The problem of Kelsenism is in this regard merely a special (and specially baffling) case of the problem as to the proper "level" of discourse for juristic theory generally. Cf. the relevant text and footnotes, Alp Ross, On Law and Justice 8-11, 25-26 (1958). 
particular system offered. This kind of activity would from the existentialist viewpoint be rejected outright, as an unwarranted encroachment of the system upon existence.

Is Hans Kelsen's version of juristic law to be seen as description of actual law; or as rational reconstruction of actual law; or as description of the oughtness of law; or as cipher-representation of the oughtness of law; or as actual law itself; or as cognition of actual law? If the question refers to what Kelsen himself sees himself as doing, then only Kelsen himself can answer. Probably he would claim to be engaged in three or four of these o activities at once. But if the question refers to how we can make sense in our own minds of what Kelsen is doing, then it may well be that what I have here called the cipher-representation of the oughtness of law is the most illuminating characterization that we can make of the whole "pure theory," or at least of those parts of it that have baffled and confounded his critics since the theory was first proclaimed.

Third, and by way of illustration of this, the present approach would throw new light on the puzzle that, right at the very heart of this archmonistic system, there seems to be a dualism as to the nature of the basic norm itself. The basic norm is presented both as the highest norm of the legal system, "the last reason of validity within the normative system,"138 and as "a hypothetical norm which actually does not stand inside the systems of positive norms but first of all founds these systems."139 On the present interpretation there would be not two, but three; basic norms on the "levels" respectively of "actual law," "the oughtness of law," and "juristic law." The "basic norm" of "actual law" would consist of the fundamental legal norm (or more probably the fundamental cluster of norms) ${ }^{139 a}$ creating the lawmaking competence from which the other norms of actual law were derived. This would be "the highest norm of the legal system," what Stone calls the "intrasystemic" basic norm. ${ }^{140}$ The "basic norm" of "the oughtness of law" would be, of course, the Transcendent Basic Norm; this would be Stone's "extrasystemic" basic norm, which "founds" all positive legal systems. Finally, the "basic norm" of juristic law would be the "cipher" which the jurist constructs of the Transcendent Basic Norm, Kelsen's epistemological "hypothesis" set up to facilitate juristic cognition. This would be "extrasystemic" to the

\footnotetext{
138 Hans Kelsen, General Theory of Law and State 111 (trans. by A. Wedberg, 1945; 20th Century Legal Philosophy Series, Vol. 1).

139 Op. cit. supra note 127 , at 104 .

139a Cf. the criticism in Fuller, op. cit. supre note 6 , at $140-141$, of the tendency in H. L. A. HART, The Concept of LAW (1961), to slur from a multitude of criteria of legal validity to something called "the rule of recognition"; and Hart's reply on this point in his Book Review, 78 Harvard Law Review 1281, at 1293 (1965).

140 See article cited supra note 128 , at 44-46; and op. cit. supra note 2, at 104-105, 124-125.
} 
actual legal system, but "intrasystemic" to the projected system of the jurist. As a cipher, it might be formulated at whatever level of abstractness best suited the particular purpose that the jurist had in hand. If his purpose were to build a "rational reconstruction" of some particular legal order's "actual law," then his cipher of the basic norm would be in terms fairly close to those of the highest norm of the legal order concerned. If his purpose were to build a cipher-representation of the whole "oughtness of law," his cipher of the basic norm would be in much more generalized terms - much closer, that is, to the Transcendent Basic Norm.

In all this we have, of course, wandered far into the marshes of metaphor, and correspondingly far from the Irrlicht of Kelsenism; for even though we have encountered some odd echoes of Kelsen's more mystical moments, Kelsenism and existentialism are probably incompatible. ${ }^{141}$ What I want to do now, however, is to press metaphor even further. For, thus far, my whole account of a search for the basic norm in the Transcendence of Being has been based on the German existentialists' account of the fullness of Being. When, however, we turn to Sartre, we find that precisely at this point precisely in place of "fullness" and "transcendence" - we are face to face with the most incomprehensible of the existentialist concepts: the concept of nothingness. For with Sartre, as we have seen, "Being itself" becomes l'être-en-soi, which still contains a sort of fullness, but a "doughy," dead sort of fullness; and the human being, l'être-pour-soi, which man becomes and is in the bounding-leap, is not a superbeing, which would (if possible) be even more heavy, solid, stupid and meaningless than being-in-itself, but a "decompression of being." The establishment of being-for-oneself occurs through a "gap" in being; it creates a doubt about being; it is the victory of nothingness. In human existence, being is pervaded by nothingness.

The concept of nothingness is present in all existentialist philosophies. Jaspers, too, speaks of nothingness (das Nichts) as in one sense constituting "authentic being as the non-Being of everything definite."142 But it is only in Sartre that nothingness worms its way into the central place and becomes a paradoxical hollowness in Being. It is possible to give a fairly good account of Jaspers' and Heidegger's philosophies without mentioning nothingness, and I have here tried to do this simply because the concept is so incomprehen-

141 Thus Georg Cohn's work cited supra note 9 moved Kelsen to comment acidly that "Just as a prevailing fashion in the metropolis will first - or still - be followed in the provinces when, in the former setting, it is already beginning to slacken, so Existentialism, which has already outlived its value in philosophy, now attempts to find a foothold in legal science." See Kelsen, Existentialismus in der Rechtswissenschaft? 43 ArchIv pür RechtsUND SOzIALPHILosophie 161, at 161 (1957).

142 Philosophie 712 (edition cited supra note 102); and cf. for existentialism generally H. KuhN, Encounter with Nothingness (1951). 
sible. ${ }^{143}$ But at this point it is also unavoidable; for just as the basic norm interpreted ' $a$ la Heidegger can be seen to be filled with the fullness and transcendence of Being, so on a similar interpretation $\grave{a}$ la Sartre it would be seen to be pervaded by nothingness. At best, this would reduce the basic norm to "the contentless content of formal juridical logic";144 at worst, it would mean that the hollow emptiness of nothingness would pervade the whole legal system.

'This is a thought capable of shaking a lawyer's very Existenz; and the existentialist stress on "meaninglessness" is not much better. "Meaninglessness" and "nothingness" alike, indeed, point to the fundamental existentialist challenge to the ordered realm of the law. It is as if the lawyer who is on the side of Jaspers' "Law of the Day" found his expected allies in philosophy aligning themselves under the opposing flag of "the Passion for the Night."145 Legal realists 146 and "policy scientists"147 (not to mention Supreme Court Justices) should by now have made us well aware that the solid "Being" of the legal rules we rely on is shifting and illusory; but we remain professionally committed to denial of this. The lawyer or judge is debarred in advance from concluding that a rule is "meaningless"; he must find a meaning even where there is none.

Yet, as students of the law, we cannot really deny the meaninglessness and nothingness it contains. The point is not merely that we sometimes find "gaps" in the law, or "space devoid of law."148 No doubt these gaps and spaces do obtrude "nothingness" into the legal enterprise; but this is, as it were, a kind of neutral nothingness, into which law can readily be extended. 149 It is not the oppressive "nothingness" that gives rise to Sartrian anguish. Nor

143 The existentialist would of course attribute this reluctance to talk about nothingness rather to its disturbingness than to its incomprehensibility. He would then argue that if we find the concept disturbing, this is precisely because we do have a partial sense of what Sartre means by talking about the nothingness that is in our being; and that if we deliberately hold back from following up this partial sense, we do so only because it fills us, as Sartre would say, with fear and shame. Pérhaps he is right.

144 A. S. de Bustamante, Kelsenism, in Interpretations of Modern Legal Philosophizs 43 , at 47 (ed. by P. Sayre, 1947).

145. See supra at note 135 .

146 See, e.g., the early writings of Karl Llewellyn and Jerome Frank.

${ }_{147}$ See, e.g., M. S. McDougal, Law as a Process of Decision: A Policy-Oriented Approach to Legal Study, 1 Natural Law Forum 53, at 54-55 (1956).

${ }^{148}$ See the discussion and citations in STone, op. cit. supra note 2, at $188 \mathrm{ff}$. And cf. with the present existential reading, НоммEs, op. cit. supra note 13 , at $148 \mathrm{ff}$.

149 Even then it may be salutary sometimes to recognize this kind of "nothingness" as such. Where, for instance, new kinds of facts create legal "gaps" but do not intrinsically call for an immediate decision; the frank recognition of a legal "gap" may allow the judge to reserve his choice for a more appropriate later occasion, when he may know more about both the situation and how best to cope with it. Insistence that there is no "gap" forecloses this possibility. See Stone's discussion cited supra note 148 , and the fuller discussion in his article Non Liquet and the Function of Law in the International Community, 35 British Year Book of International LAw 124-161 (1959). 
is the point merely that even in the "law-filled" spaces where we do have legal rules, those legal rules are strictly "no thing"; that they are not what a rigid empiricist would recognize as respectable empirical data.150 Nor is it even that through oversight or ineptitude in legislative drafting, ${ }^{151}$ or confusion and vacillation in judicial decision, ${ }^{152}$ our legal materials sometimes present us with patent obscurities, self-contradictions, and absurdities. No doubt it is true that where a legal rule is so obscure as to make interpretation impossible, or where by patent self-contradiction it cancels out its own effect, we really do have areas of meaninglessness or nothingness in law. But while these patent examples are rather inescapable, they are usually also rather trivial. ${ }^{153}$

The point is rather that even where we have legal rules that are not obviously self-contradictory or empty, they are spun out of nothing but "words, words, words." This, when we think it through, carries two implications which are of "nothingness" in the oppressive Sartrian sense. One is that all legal rules, not merely those with patent defects of expression, are subject to the inherent difficulties of language as a means of expression. All legal rules are at best of imperfect, indefinite, and variable meaning. ${ }^{154}$ Nothing in law is certain or settled; there is no firm ground on which we can rest. The other implication is that this tenuous web of words rests upon nothing but words: law holds itself up by its own bootstraps, and these are merely verbal bootstraps. ${ }^{154 a}$

For this tenuousness or emptiness which pervades the whole of law, the Sartrian nothingness is an apt figure. In its terms we may say that in the

150 This kind of view is at the heart of the argument in W. L. Morison, Some Myth About Positivism, 68 Yale Law Journal 212 (1958).

${ }^{251}$ See among the nicer English examples the Artizans and Labourers Dwellings Act (1868) Amendment Act, 1879, s. 22(3), (requiring transactions to be effected "in the form set forth in the Third Schedule hereto," where there was no Third Schedule); and the Intestates' Estates Act, 1890, s.6 ("the testamentary expenses of the intestate").

152 See, e.g., the Privy Council's advice in Lord Strathcona Steamship Co. v. Dominion Coal Co. (1926) A.C. 108. In Port Line Ltd. v. Ben Line Steamers Ltd. (1958) 2 Q.B. 146, Diplock, J., finally held that that case had no discernible meaning, and refused to follow it. Cf. on National Mutual Insurance Co. v. Tidewater Transfer Co., Inc., 337 U.S. 582 (1949), STone, op. cit. supra note 2, at 255n.

153 But not necessarily so. The "meaninglessness" of much of the statutory language in the English and Australian fair rents or rent restriction statutes, for example, is both patent and crucial. See the judicial criticisms collected in R. B. Mroarry, Miscellany-At-Law 351354 (1955; revised impression 1956). And see generally Tammelo and Blackshield, article cited supra note 61, esp. at 35-39.

154 See Stone, op. cit. supre note 2, at 241-300, 339-346. And cf. J. D. Hyman \& W. J. Newhouse, Standards for Preferred Freedoms: Beyond the First, 60 Nortuwestern UNIVERSITY LAW Review 1.93 (1965).

1548 So that after the initial astonishment had passed, what was finally remarkable about Justice Douglas's opinion for the majority in Griswold v. Connecticut, 85 S. Ct. 1678 (1965), was not that the decision lacked any "solid" basis, but only that words like "penumbra" and "emanations" made this more than usually patent. See esp. 1681. 
being of law, as for Sartre in the being of each pour-soi, the awareness of nothingness may lead to any of three reactions. First, it may lead to nihilism, despair, or at any rate jaundiced cynicism about the whole legal enterprise. Judges or practitioners who set out with the high ideal of sharing in the regulation of human problems by the rule of law, may find their ideals soured or shattered by an awareness of the emptiness of law. But, second, they may see this emptiness as giving them maneuvering space through which they can struggle to ground their decisions not on the void of the law itself, but on moral standards and values. Sartre himself, as we shall see, would say that these moral foundations are as empty as the legal ones; but whether or not this is the case is a separate question, which is at any rate not foreclosed by awareness of legal emptiness. Moral standards, too, are necessarily verbal; but not necessarily merely verbal. Third, in any case Sartre himself would urge that the awareness of nothingness should lead us not to mere despair, but to a recognition and a fuller exercise of the creative freedom that we ourselves are. This is not necessarily inconsistent with the second reaction. Once legal nothingness is seen as creative freedom of choice, we can more frankly address ourselves to what really takes place in the working of the judicial process. Judges can be more honest with themselves; and can more freely shape their decisions to meet changing social needs when it is desirable to do so.

Yet, of course, however important all of this may be, it is scarcely of any jurisprudential novelty. In thus pointing the way through nothingness to judicial freedom of choice, our existentialist metaphors merely reinforce analyses and desiderata which have long been familiar to most lawyers on other grounds and through other versions arrived at independently of existentialist support. If existentialism, or the relevant aspects of it, convince us or even merely attract us, we may avail ourselves of this further support; but this does not mean that the positions referred to are dependent on the existentialist analogies. Here those analogies enable us at most to express old ideas in a new way.

B. The Individual and "the Crowd." - Sociological jurisprudence, now more barbarously known as "law-society,"154b seeks to be both a descriptive and a prescriptive discipline. Working for the most part with insights and concepts, theories and facts, derived from the other social sciences, it seeks to use these on the one hand to illumine our understanding of the nature and

154b See, e.g., Symposium, Law in the Liberal Arts, 14 Gatholic University Law Review 149-191 (1965), esp. Albert Broderick, O.P., "Law-Society" in the Liberal Arts, at 176-191. 
workings of legal phenomena in society, and of their connections with other social phenomena such as shared values and organized power; ${ }^{155}$ and on the other hand to guide us to an awareness of the social problems that law should seek to solve and of the ways and means of making our solutions socially effective. ${ }^{156}$ As a descriptive, cognitive social science it inevitably works with collectivities as the main foci of analysis, whether these be thought of as social groups, or as social "institutions." On the prescriptive side the sources of group-orientation are threefold. First, both the problems that need to be solved and the available techniques of solution will largely depend on the efficacy of collective groups in creating and furthering, but also overriding and distorting, individual human purposes. ${ }^{156 a}$ Second, since any guidance it can give must be rooted in the fact-gathering and fact-organizing activities of the descriptive social sciences, the juristic use of social science will inevitably share the group-orientation of those other disciplines. Third, the broad overall enterprise of social control through law must in spite of itself entail some degree of implicit value-drive; and this must tend to 'be in terms of what is good for "society" as a whole. This is not to say that even the most aggressively prescriptive sociological jurisprudence is on that account socialistic, but only that the very idea of "sociological engineering" tends to direct the engineer's vision over the heads of particular individuals. Both descriptively and prescriptively, therefore, sociological jurisprudence seems at first sight diametrically and irreconcilably opposed to the passionately individualist orientation of existentialism. Yet on

155 See N. S. Timashefp, An Introduction to the Sociolooy of Law 12-17, 245-268 (1939); Julius Stone, Social Dimensions of Law and Justice ch. 9-13 (forthcoming, $1965)$; Lloyd, op. cit. supra note 125 , at $26-69$.

158 See Stone, op. cit. supra note 155, ch. 4-8 and 15. The above "prescriptive" aims are of course "prescriptive" in a limited sense only, stopping short of any attempt to prescribe ethically right solutions for the problems studied. "Sociological jurisprudence" is both more and less than a theory of justice. It is simply social science applied to legally relevant phenomena. Confusion on this point sometimes arises because of (i) the secretion of Roscoe Pound's pragmatist theory of justice within his sociological jurisprudence; (ii) the general involvement of social science with the study of "values" as actually held; (iii) specific claims to use the values thus studied as a basis for normative judgment, as in F. S. C. Northrop, Ethical Relativism in the Light of Recent Legal Science, 52 Journal or PhiLosOPHY 649-662 (1955), and semble in P. Selznick, Natural Law and Sociology, in Natural Law and Modern Society 154 (ed. by John Cogley for the Center for the Study of Democratic Institutions, 1963). This is not the place to pursue these confusions. See generally Stone, op. cit., ch. 1 passim, esp. at 7-8, 12-14, 64-66; and ch. 12, sec. 1, esp. at 548 note 2. Confusion might still perhaps best be averted by reference to Pound's eight-point "program" for sociological jurisprudence, now half a century old. See R. Pound, Scope and Purpose of Sociological Jurisprudence, 25 Harvarl Law Review 513 (1912).

Confusion has also sometimes arisen from a priori efforts to give "sociological jurisprudence" some meaning which will distinguish it from "sociology of law" or "sociology including law in its scope." The pointlessness of such efforts has long been apparent. For a good recent discussion see Grofprey Sawer, Law in Society 16-26 (1965).

156a See Stone, op. cit. supra note 155 , at $277,300,339-40,386,485-86,560-65$, and ch. 7, 11 passim. 
both levels of this apparent conflict, the descriptive and the prescriptive, I believe that a certain amount of complementarity and even of agreement is possible.

First, then, as to the prescriptive issue. In the broadest terms, this is simply the question whether our social arrangements should be geared to the requirements of the individual, or to those of society. This way of formulating the question reminds us at once that here again we are directing our minds to an issue as old as philosophy itself; 157 $^{\mathbf{1}}$ and the first noteworthy feature of the confrontation in this ideology-scarred field between sociological jurisprudence and existentialism is that both bodies of thought lead to the conclusion that most of the past controversies have been diverted from cogency by misleading statements of the problem. Existentialism denies that society can have any meaning apart from the individuals who constitute and "pro-ject" it.158 A similar stand, whether we see it as paradox, synthesis, or both, underlies much writing in the field of social control through law - whether in the late Roscoe Pound's account of the relation between individual and social "interests," 159 or in the eternal polemics on the proper role of "planning."159a Moreover, both sociology and existentialism share the further common feature of having received their original stimulus, in very large measure, from a growing anxiety over the increasing danger of the individual human person being swamped by the mushrooming of giant impersonal social entities which has characterized the past century. ${ }^{160}$ An important part of the work of existentialism has been to analyze and characterize the various "inauthentic modes of being" by which this development crowds out the individual who seeks to assert his individuality; ${ }^{161}$ and an important part of sociological work right up to the present has been to document instances of the submersion and deracination of the individual by urbanization, proliferation of technologies, and the steady burgeoning of mass media, whether or not deliberately manipulated. ${ }^{162}$ What remains to be

157 Cf. FriedmanN, op. cit. supra note 13, at 34-38.

$158 \mathrm{Cf}$. the collection of existentialist views on this matter in TIRYARIAN, op. cit. supra note 29 , at $125-144$.

150 See Stone, op. cit. supra note 1, at 265, $271 \mathrm{ff}$.; STone op. cit. supra note 155, at 171 ff., 181-182.

168a See, e.g., Kard Mannheim, Man and Society in an Age of Reconstruction (1940); E. V. Rostow, Planning por Freedom (1961). Rostow's very title makes the point neatly, though of course oversimply. The central place of "individualization, of justice" in Pound's 1912 "program" for sociological jurisprudence (supra note 156) might also be vouched.

160 See as to existentialism Thryakian, op. cit. supra note 29, at 76, 125-126, 151; and as to sociology the extensive treatment of Durkheim in id. at 11-68. See also on Durkheim Stone, op. cit. supta note 155, at $148 \mathrm{ff}$.

161 See, e.g., Heidegger's analyses cited supra note 75.

162 See Stone, op. cit. supra note 155 , at 154-163; L. Bramson, The Poltricat ConTEXT OF SOctolOOY (1961). 
seen is whether either existentialism or "social engineering" can yield a solution to the problem. ${ }^{163}$

Of course, this very statement of the problem may seem to point toward at least a broad solution. It suggests that in affirming that the individual must accept what is best for all, but what is best for all must be determined in the light of what is best for individuals, we may well be approaching a formulation on which both "social engineers" and at least the more moderate existentialists would agree. Both Jaspers and Heidegger would recognize (if they were to address their minds to the question at all) that the individual for whom we must legislate is an individual in society.

Yet even then, the existentialist individual is such a subjective and such an undetermined being (his being, it will be recalled, consists only of potentialities, and these are boundless) that it is rather impossible to legislate for him, or to do him justice by any kind of legally regularized social arrangements. Thus far, the existentialists' contribution to their dialogue with the sociological approach may seem only negative - a simple warning that social arrangements can never adequately do justice to the individual. To couple this warning, moreover, with an insistence that "justice" is what social arrangements must do, leaves us worse off, rather than better. Is there any way in which existentialism can press beyond its mere concern with the individual to a sociologically fruitful concept of the individual in society?

The answer cannot be satisfying, but perhaps in the works of Jaspers we can find what amounts at least to yearnings towards an answer. Here, as often at the critical points of his work, Jaspers pins his faith on "boundless communication"; and if the practical, real-life potential of this answer is unpromising, it is nevertheless a potential that we cannot afford to neglect. Jaspers' ideal vision is of a practical unity of men striving for freedom from hatred and violence, this unity being founded on "boundless communication" arising out of mutual understanding and love between free individuals. He dreams of the end of violence "through a constitutional order which, though unjust, is moving towards justice." He does not think that "this goal of unifying mankind at least on the basic levels of life" is either a totalitarian monstrosity or a mere utopian dream. On the contrary, he says, in words which bring the challenge squarely to the portals of the law:

Prerequisite for such a unity is a political form upon which all can agree, since it provides the best possible basis of freedom for all. This form, which only in the West has been developed in theory and in part

163 TIRYAkIAN, op. cit. supra note 29 , never finally confronts this question, though it is central to his whole study. 
realized, is the constitutional state built on elections and on laws which are subject to modification solely by legal means. In such a state men battle to gain recognition for the just cause, to win public opinion through widespread and enlightened education and the unreserved dissemination of news.

There would be no wars in a constitutional world order where no state would possess absolute sovereignty but mankind itself, acting through its constitutional organs, would be sovereign. ${ }^{164}$

At the same time, such existentialist constitutionalism differs toto caelo from that of contemporary theses, such as that of John Rawls, ${ }^{165}$ based on a revised version of the "social contract." As Fritz Kaufmann has strikingly put it, Jaspers' aim is one of "co-Existenz"; of "social contact, not social contract."166 The world that Jaspers envisages is one in which "the contact with others elicits selfhood." 167 The foundation us community can never be a formal binding together of individuals, but continual unfettered flow of communication between them arising ever anew from wills which must not be fettered - not even self-fettered. ${ }^{168}$ Only communication can lead to authentic communification. Here, as indeed always, Jaspers' search for philosophical guidance finally comes to rest in an appeal to Love. ${ }^{169}$

I turn now to the second apparent conflict between sociology and existentialism, that of the cognitive handling of the phenomena of men in society. Which is to be the working unit in picturing these phenomena: the individual

164 Einführuno in die Philosophie 102 (Way to Wisdom 106-107).

165 See esp. J. Rawls, Constitutional Liberty and the Concept of Justice, 6 Nomos 98 (1963).

168 Kaufmann, essay cited supra note 55, at 214 ; cf. id. at 223.

$1671 d$. at 275 .

${ }^{168}$ By the same token mere technical improvement of the media of international communication may be no assistance, and even an obstacle, to the authentic communication that is required. See Julius Stone, Legal Controls of International Conplict xli-xliv (1954); Arendt, essay cited supra note 56.

169 Pace Kaufmann, essay cited supra note 55, at 256-258. See infra p. 133. Jaspers' views on "communication" and "love" find interesting parallels within the existentialist universe of discourse in Nicolas Berdyaev, Solitude and Socizty (trans. by G. Reavey, 1947), and in G. Marcel, Les Hommes contre Humain; and in our own legal philosophical universe of discourse in the tentative postwar reformulations of Gustav Radbruch's legal philosophy. See Erik Wolf, Revolution or Evolution in Gustav Radbruch's Legal Philosophy? 3 Natural Law Forum 1 (1958); Ilmar Tammelo, La Relativitd della Giustizia ed il Principio della "Sollecitudine," 35 Rrvista Internazionale di Filosofia det Diritto 265 (1958), revised and reprinted in English under the title Ideas of Justice and Caritas Sapientis, 2 Jaipur Law Journal 51 (1962). And see Stone, op. cit. supra note 1, at 250, 256, 260-261. From the viewpoint of the history of ideas, indeed, one of the most interesting lines of further inquiry for a juristic study of existentialism would be to explore the extent to which Radbruch and Jaspers influenced each other's ideas while at Heidelberg, and the extent to which both were influenced by their shared devotion to Max Weber. Some of the starting points for such an inquiry are opened up by Wolfgang Friedmann, Gustav Radbruch, 14 VANDERBILT LAw Review 191, esp. in text and footnotes at 198-199 (1960). And see as to Jaspers and Weber infra note 176. 
or the group? Here, too, the answer may lie in reformulation of these antithetical positions.

The whole of Kierkegaard's philosophy is clearly built on the distinction between the individual and the crowd; yet the distinction seems already blurred in the German existentialist writings, and likely to be still further blurred as existentialism becomes more moderate and itself "understands the individual" more fully. The fact is that one essential feature of my existence as a human individual is my relationship with other individuals. Existence must always find itself inescapably "in a situation": this itself is one of Jaspers' "limit-situations." 169a As Heidegger put it, human existence is defined ontologically by its having ontological "place"; and this "place" is defined not merely ontologically, but historically and sociologically as well.170 It is a kind of field of awareness, which is permeated by understanding, mood, and "language" (in an extended sense corresponding to Jaspers' extended use of "communication"). "To have 'place' ontologically and empirically," say the translators of Heidegger's Uber "die Linie" in their Introduction to the English version, "is to have a house in which being can unfold itself and manifest its Being." They go on to maintain that this "place" must in part be delimited by a sociological dimension, which intersects, as it were, with the ontological dimension. ${ }^{171}$ They illustrate this intersection with a striking demonstration of how existential analysis of man, in his historical, sociological situation, can be applied to a legal situation. ${ }^{172}$

168a Prilosophie 469 (edition cited supra note 102).

170 See Sein und Zeit 53-54 (Beino and Time 79-80). And cf. Richardson, op. cit. supra note 30 , at $277 \mathrm{ff}$.

171 Op. cit. supra note 88 , at 26 , and generally $18-26$. And cf. id. at 13-16.

172 Id. at 21-24. The example turns on the defiance of Henry III by the Earl of Pembroke ("Richard the Marshal") in 1233 (see William Stubes, 2 Constitutional History or Enoland 48-49 [3rd ed., 1887]; and the full account in F. MaUrice Powicke, 1 KINo Henry III and the Lord Edward 125-151, esp. at 146 [1947]). The discussion is based on the Earl's detailed justification of his stand, as reported by Roger of Wendover in his Chronicles ("Flores Historiarum"). See the Rolls House edition sub nom. Chronica Rogeri de Wendover (ed. by H. G. Hewlett, 1889), vol. 3, 65-68. Kluback and Wilde point out that the rights on which the Earl insists are rights in defense of and arising out of his "place" in relation to his land, and to his king and peers. Conversely the king's infringement of these rights is such because the Earl himself has not (as Henry's claims imply) violated the "place" of others. It was Henry who by laying siege to the Earl's castle (and stripping him of his office of Marshal) had violated his "place"; and against such a violation any means of defense whatsoever would be justified. In short, the whole feudal context of this dispute betokens

the concern of man for preservation of "place." Through the acquisition of land man receives rights but also owes rights. Land becomes an essential condition of his place; it becomes the sine qua non of the dwelling in which he is conscious of his dimensions both vertically and horizontally. Vertically, it is the place which permits him to reveal the justification of his existence. On the other hand, it is place which relates him to others, his king and fellow barons. (Op. cit. at 22)

Nor is it land as such which constitutes this jealously guarded "place": the Earl insists that 
The point is that to understand the individual (as the existentialists try to do) I must understand him in his situation (as the sociologists try to do) ${ }^{\mathbf{1 7 3}}$ Man's existence is uniquely structured by the social and legal frame in which it is set; it permeates a space whose limits are externally drawn. Existential analysis, working (as it were) from inside, cannot adequately picture or even comprehend these limits.

But the converse is also true. A social science approach seeking merely the general "laws" of these limits must miss a great deal of intricacy and importance in the dynamics of human society. In jurisprudence as elsewhere, a worthwhile social science must build on the study of individuals in the uniqueness of time and place - on all the unique experiences of all the disparate human existences, in all their historicity and contingency. ${ }^{\mathbf{1 7 4}}$ Naturally, existentialism and sociology will still approach this study of the individual from different angles. Sociology is concerned to amass detailed items of objective knowledge about human existence; and even when it does attend to individual existence, this objectivity. remains both its central aspiration and its inevitable -limitation. The more social scientists turn to behavioralist

he is not protecting "worldly possessions," but jeopardizing them for the sake of "justice." $\mathrm{He}$ is asserting "rights and obligations" as "a dweller on this earth," and these "not only fixed his uniqueness but related it to society. Thus society was a fabric woven from relations recognized as having their source in individuality and proceeding from individuality to community. Dwelling points to itself and beyond itself"; the Earl's rights are "rooted in the fact" of his "place." "His being there is the concretization of rights inherent in the 'being there' already." Id. at 24.

And cf. C. Petir-Dutaillis, 1 Studies and Notes Supplementary to Stubes' Constirutional History 55 (trans. by W. E. Rhodes, 1908), venturing the generalization that "the distinction even between free and non-free in this country was practically a distinction between tenures much more than a distinction between persons." The real point is of course that feudal tenure of land, with its attendant cluster of rights, is itself an intensely personal affair. Cf. the striking attempt to articulate this elusive but crucial quality of a man's position under African "feudalism" in MAX Gluckman, The Ideas in Barotse JURISPRUDE NCE $75 \mathrm{ff}$., $140 \mathrm{ff}$. (1965). See esp. 86-88, 109-110 (comparisons with European feudalism), 90, 95-96 (the need for a new concept of "estate"), 101-103 (the individual personality as pivotal), 123-127 (succession to title), 148-155 ("bung'a" - ownership - as undifferentiated rights, duties, status, and social position), 163-166 ("bung'a" and personal relations). What Gluckman's Barotse here have in common with European feudalism may be precisely the importance of "place."

${ }^{173}$ This seems to be the gist of the unnecessarily obscure and in any case rather lame conclusion in TIRYAKIAN, op. cit. supra note 29 , at 163 , that "an important bridge between sociology and existential philosophy" lies in the realization "that being-in-society is an intrinsic existential structure of human-being." The point emerges more forcibly from Pruetze, op. cit. supra note 17, an exhaustive study of the congruence, complementarities and contrasts between the ideas of Martin Buber and George Herbert Mead. Cf. Hommes, op. cit. supra note 13, at $83 \mathrm{ff}$. And see Stone, article cited supra note 8, at 153-155, 161; and STone, op. cit. supra note 155, at 26n. But see the caveats infra at pp. 141-42.

174 This approach is increasingly applied, with invaluable results, in the study of history. For a recent example see C. Hirl, Society and Purrtanism in Pre-Revolutionary ENGLAND (1964), contrasting nicely in this respect with the classic study by R. H. TAWNEY, Religion and the Rise of Capitalism (1926). 
methodology, the more they are limited to seeing only from outside. Their descriptions come increasingly to cluster around a gap. ${ }^{174 a}$

It is precisely this gap that existentialism aspires to fill. It shies away from objective knowledge, ${ }^{175}$ seeking instead to "illuminate" (erhellen), by its whole range of evocative and impressionistic devices, our "understanding" of the subjective meanings of this existence for individual existents. But in this very difference we may finally come to see a complementarity. ${ }^{\mathbf{1 7 6}}$ Objective knowledge may give structural "place" to our understanding of man, but only existential knowledge can fill the interstices of this "place" with the feeling of what is known. ${ }^{177}$

C. Existentialism and "Values." - We have already seen that the existentialist stress on the contingent individual existence is finally inconsistent with the Kelsenite type of analytical juristic "system." It is important to note that for precisely the same reasons the existentialist premises seem to require us also to reject many traditional manifestations of natural law thought. Not the least interesting feature of this result is the way it underlines the resemblances between analytical and iusnaturalist "systems."

Whether any form of natural law is consistent with existentialism is, however, a separate question. It seems clear enough that no elaborate working out of detailed principles of natural law can be thus consistent; for any such working out must be strongly tainted with the bete noire of the "system." But we may be able to build a certain kind of natural law on existentialist premises, though it will be a very bizarre kind, so remote from any usual

\footnotetext{
$174 a$ The gap is strikingly symbolized when the "attitudes" now much studied by social science are treated as "latent variables," inferred entities which cannot be explored, but must simply be taken as implied in the observable data. See, e.g., P. F. Lazarsfeld, The Logic and Mathematical Foundation of Latent Structure Analysis, in S. A. STOUFfer et al., Measurement and Prediction 362-412 (1950). But, of course, the very concept of "social roles," for all its current ubiquity, is similarly only a name for a "gap" to which expectations and responsibilities are externally attached.

175 Cf. W. Earle, Anthropology in the Philosophy of Karl Jaspers, in The Philosophy op KARL. JAspers, cited supra note 26,523 , esp. at $524,530$.

176 See id. passim and cf. G. Mann, Freedom and the Social Sciences in Jaspers' Thought, in the same work at 551. So Jaspers' philosophy finally emerges as complementing, rather than building upon, the sociological insights of his mentor and idol, Max Weber. See in the same work E. M. Manasse, Jaspers' Relation to Max Weber, at 369, and Jaspers' Reply to My Critics, 749, esp. at 865-866.

${ }^{177} \mathrm{Cf}$. the extensive reliance on existentialist influences by many modern psychologists in both Europe and the U.S. Tiryakian, op. cit. supta note 29 , at 79,99 , cites a number of examples including Ulrich Sonnemann, Existence and Therapy (1954); R. D. Laing, The Divided Selp: A Study of Sanity and Madness (1960); and the collective work, Existence: A New Dimension in Psychiatry and Psycholooy (ed. by $R$. May, E. Angel, H. F. Ellenberger, 1958), in which see esp. Rollo May, The Origins and Significance of the Existentialist Movement in Psychology, at 18. And cf. K. F. ReInhardt, The Existentialist Revolt 244-267 (2nd ed., 1960).
} 
meaning of the term "natural law" that most natural lawyers will probably refuse to acknowledge it as such at all.

This remoteness from the traditional understandings of "natural law" arises in three different ways. First, I believe, there cannot for any consistent existentialist be any actual "laws" inherent either in Being or in the worldly phenomena, the data of nature, which Jaspers, at least, sees as the "ciphers" of Being. A law is a concept, with a characteristic conceptual form; and this, moreover, is a conceptual form which is characteristic of human thinking. Even if we assume that certain contents which we can interpret as obligations are inherent in Being, or in worldly reality, we cannot assume that concepts having a characteristic human form are thus inherent. If like the Christian existentialists we are prepared to think of Being-itself not only as God, but as an intelligent God, then His intelligence will presumably contain certain concepts; but even then we cannot expect them to take a form which is characteristic of human thinking. ${ }^{178}$ Even if we claim to find obligations inherent in Being or in the world, to speak of these obligations as "natural laws," or to formulate our account of them in the form of norms, is to superimpose an alien form on the obligations we speak of, or at best to create human "symbols" or "ciphers" which only more or less express, in a metaphorical way, the obligations themselves. Indeed, to speak of these latter as "obligations" is equally only a "cipher."

The two further divergencies between traditionally understood "natural

178 See my article cited supra note 89, at 508-511. Plattel, article cited supra note 57, strives to overcome such problems in three complementary ways. (1) His basic stress on "historicity" has already been discussed (supra note 57). (2) Interwoven with this is a stress on the "subjectivity" of natural law, as opposed to the "objectivity" which he thinks has traditionally been ascribed to it. He here seems merely to be denying that natural laws exist as "immutable, supratemporal natural principles" independent of their application in historical situations. He is saying, in effect, that natural law must be understood as emerging within human situations, not as impinging on these from outside. See pp. 16-17; and the much fuller discussion of "subjectivity" and "objectivity" in Hоммes, op. cit. supra note 13 , at $97 \mathrm{ff}$. Certainly our present difficulty in thinking of natural laws as "laws" is more acute if they are thought of as objective "laws" in Plattel's sense; and if we think of them rather as subjective "laws," the difficulty may disappear. For obviously the subject who in Plattel's words "must fashion" his values may fashion them in law-like form. Yet even while this formal difficulty is eased, the substantive difficulty in thinking of self-made values as "natural laws" is exacerbated. And at this point Plattel falls back on merely verbal escape routes, including an obfuscating appeal to the scholastic distinction between univocal and analogous concepts, and "paradoxes" that are really flat self-contradictions. See p. 21. The contrast at 36-37 between "ethical" and "legal" natural laws is much more promising. But since "legal" natural laws are ex hypothesi what jurisprudents are concerned with, we are merely returned to the original dilemma. (3) There are undeveloped suggestions (e.g., at 17) that "subjectivity" is here to be understood as "intersubjectivity," the individualism of existential valuings being then presumably overcome by their relational character. Yet "intersubjectivity" as a jurisprudential concept leads naturally neither to existentialism nor to natural law. See Giorgio Del VecGHo, Justice: AN Historical AND Philosophical Essay (trans. by Lady Guthrie and ed. by A. H. Campbell, 1952); and the analysis in Blackshield, article cited supra note 60 , at $54 \mathrm{ff}$. and passim. 
laws" and those which a consistent existentialism might offer both arise from existentialism's extreme individualism. One is that the "obligations" which I have spoken of must be seen from the existentialist viewpoint as obligations which each individual must discover for himself, and the "ciphers" which humanly represent them must be seen as ciphers that each individual must formulate for himself. Not only can there be no authoritative statement of obligations imposed on each individual's personal ethical freedom and ethical responsibility; there cannot even be any universal homogeneity of the obligations themselves. Moreover, the obligations which we are discussing must be unique in their occurrence as well as in their obligations. Borrowing the terminology of Norberto Bobbio's analysis of legal norms, we may say that the existentialist "natural laws" will be not only "individual" norms (addressed to individuals, not classes of persons), but "concrete" norms (prescribing only for their own particular situation). ${ }^{179}$ Every fact situation, indeed every element in every fact situation, must carry its own unique obligation. But to speak of "natural laws" ordinarily implies that in formulating the obligations expressed it is not necessary to deal with individual phenomena or human beings separately and one at a time, but that they can be subsumed under classes: so that to limit the range of "natural laws" exclusively to

\footnotetext{
179 Norberto Bobbio, Teoria della Norma Giuridica 227-242 (1960). For a brief summary of Bobbio's terminological clarifications here see STone, op. cit. supra note 2, at 201. Of course Bobbio is not here addressing himself to natural law problems, let alone to the apparent incongruity between natural law and existentialism.

Kierkegaard's anguished reworking in FEAR AND TREMBLING of the story of Abraham and Isaac might conceivably be developed into a way out of this incongruity. The development is almost reached, but finally remains still inarticulate, in the further reworking by Maritain in his 1964 work cited supra note 19, at 362-370, where the utterly individual existentialist ethic is itself seen as a confrontation with universal norms, which grip the individual as his norms because he has "burst through the ceiling of Ethics." But that ceiling then in effect becomes a floor, on which the existentialist individual may have to continue to tread. The general norms that govern mankind are not abrogated or dissolved by the leap into existence; the general norms of existentialist "supra-ethics" may supplant them for a particular individual in a particular situation, but may also direct their observance in a more "interiorized and spiritualized" way. The source and nature of the obligation will then be different, but not its content or the generality of this. (Perhaps it is in this sense that we should finally understand Plattel's subjective/objective contrast discussed supra note 178.)

On this basis, we could not only solve the notorious scholastic puzzle of "exceptional" divine commandments (involving not only the Abraham story but Hoseah 1.2, 3.1; Exodus 3.21-22, 11.2, 12.35-36; Deuteronomy 24.1-4; and in the Apocrypha Tobias 5.18), but could also think of both ethical "levels" as "laws" whose normativity existentialist individualism must confront, but does not deny. The "lower-level" norms would be "abstractgeneral" in Bobbio's terms; the "higher-level" norms would be "individual," but would include both "abstract" and "concrete." And there would be at all events no merely conceptual reason why either or both should not (if we so chose) be thought of as "natural laws."

And see Boasson, article cited supra note 21, whose further reworking of the Abraham story (at 460) leads to the additional point that through the individual's confrontation with his "higher-level norms" the content of these may pass into the body of generally applicable "lower-level" norms.
} 
individual-concrete norms is to take away practically all the significance of the word "laws" as we commonly understand it. It is also, of course, to take away all manipulability from one situation to another; and it is then difficult to see what practical value the formulation of this kind of natural law can have. Yet I believe that existentialism is consistent only with "natural laws" in respect of which we are prepared to accept all three of the above deviations from the usual meaning of "laws": that each "law" be confined in its force to the particular situation in which it arises; that each individual create his own "laws" from his perceptions of his obligations; and that in any case their formulation as "laws" be accepted only as a metaphor for some much less structured (or at least quite otherwise structured) "obligation."

All this assumes, of course, that inherent in Being or in worldly phenomena we can find "obligations." It assumes, in short, the presence of a bridge (or a "coalescence") ${ }^{180}$ between "is" and "ought," between facts and values. Here, I believe, existentialism does offer promise of assistance to the natural lawyer, again in three different ways. The question then is whether the natural lawyer is prepared to accept this assistance at the price I have just outlined; or whether it is possible for him to be sufficiently selective in his use of existentialist themes to accept the assistance without paying the price.

The first, and I think the strongest, of the existentialist "links" between facts and values lies in the now familiar lesson that all rationally constructed verbalizations which men make in relation to reality have only cipher significance, only metaphorical meaning. This lesson applies with equal force to verbalizations of fact and to those of value. "The realm of the is" and "the realm of the ought" are simply convenient names for the two main kinds of rational verbalization that men make. To say "This man is starving" and to say "I ought to give this man some food" are equally human verbalizations of an existential situation which in itself is quite uncharacterized (or "undetermined") in either way, but which by the same token offers an equal potential invitation to either kind of response. The situation itself is simply an existential confrontation which challenges me to a response: if I respond by noting the man's starved appearance with dispassionate detachment, or cynical amusement, my response may be verbalized as an "is" statement; if I respond by feeling an impulse to help him, this may be verbalized as an "ought" statement. Of course, once I verbalize the situation by saying, "This man is starving," then I have cast that pattern of verbalization irrevocably into the realm of the "is"; there is no way I can then deduce from the sole premise "This man is starving" the conclusion "I ought to give this man some food." But

180 Cf. FULLER, op. cit. supra note 85, at $6 \mathrm{ff}$. 
even then I can always return to the existential situation itself and say, as a new verbalization, "I ought to give this man some food." If my response is of this latter kind, I have not indeed derived a value from a fact, an "is" from an "ought"; but I have responded to the obligation potential of an existential situation, and by so responding I have formulated for myself what is a "natural law" of that situation.

The second potential existentialist linkage between "is" and "ought" lies in the concept of "authenticity." An attempt to say how this concept can help us involves us once again in the whole cluster of ambiguities and contradictions which the concept was seen to breed in our earlier discussion; and the suggestions I now want to make presuppose the correctness of the analyses there offered. They also presuppose at certain subsidiary points a separate premise which is not to be found in the existentialists' discussions of "authenticity," nor for that matter anywhere in their writings. ${ }^{181}$ Indeed, it is a premise which so far as I am aware has never been expressly articulated in any discussion, though it is present as a concealed and sometimes half-articulate premise in our approach to a great many ethical problems. In legal philosophy, for instance, it is the key to such disparate problems as the relationship between Kantian ethics and nineteenth century laissez faire, ${ }^{182}$ the morality and legality of the maxim lex non cogit ad impossibilia, ${ }^{183}$ and the use of the 1964 Civil Rights Act to compel racial desegregation. ${ }^{184}$ This ubiquitous yet unobtrusive premise may be formulated simply as follows: That which ought to be, ought to be allowed to be. In other words, once we have decided that a given state of affairs is morally good or desirable, we are entitled (and indeed obliged) to make the additional moral statement that any circumstances which impede or prevent the achievement of the approved state of affairs are undesirable, and ought to be removed. Since my present use of this premise is of secondary importance only, I am not here concerned to inquire whether on the one hand it is reducible to a tautology and can therefore be asserted a priori, or whether on the other hand it is a substantial premise which is itself in need of justification. I am concerned to say merely that we all do in fact commonly use this premise, and that in any case I propose to use it in the following discussion of "authenticity."

181 Though Jaspers may conceivably be thought to be approaching something like it when he says in The Future of MANKIND (trans. by E. B. Ashton, 1961): "We cannot tell what men will freely do, which side of freedom will be realized. . . . But what we cannot know is up to us to bring about."

182 See citations supra note 1 , in both of which, however, the relationship is rather too readily assumed.

183 See Fuller, op. cit. supra note 6, at 70-79.

184 See Heart of Atlanta Motel v. U.S., 379 U.S. 241, 85 S. Ct. 348 (1964); Katzenbach v. McClung, 379 U.S. 294,85 S. Ct. 377 (1964). 
The question we are discussing is how far "authenticity" can serve as a link between facts and values. From our earlier discussion there emerged several distinct possible levels on which we might speak of "authenticity" as a value concept, and the answer to our present question will vary according to which of these levels we choose. Another way of saying this is that in applying the concept of "authenticity" to the fact-value problem, we must first decide how closely we intend to keep to our existentialist sources. In the present discussion I shall consider only the two extreme possibilities: first, that we should take over in its entirety the existentialists' understanding of the concept, including all the value judgments that they inject. into it; and second, that we should borrow only the "empty" concept of "authenticity" as such - that is, merely the bare idea that authenticity of fact entails authenticity of fittingness - and should apply this idea in a way unfettered by reference to its existentialist sources.

First, then, we are to speak of "authenticity" solely in terms of the content which the existentialist gives to the notion in applying it to human beings. In other words, we are to use "authenticity" merely as a shorthand expression for the positive valuing of self-awareness, independence, a sense of responsibility, a sense of personal commitment, and similar features of an individual's attitude towards his own behavior - features which may here be compendiously referred to as "selfhood." If we choose this meaning of the concept of "authenticity," then all that the concept does is to furnish us, in our approach to the facts of human behavior, with a premise to the effect that "selfhood" is good. The "facts" which such a premise enables us to endow with value significance will be of three kinds only, exemplified respectively by the fact that a particular individual has selfhood (any such fact being endowed by our premise with a positive value); by the fact that a particular individual lacks selfhood (any such fact being endowed by our premise with a disvalue, or negative value); and by the fact that a particular individual who is potentially capable of selfhood is prevented from achieving or maintaining it because circumstances in which he is placed operate to inhibit, suppress, or deaden it, or to cut it off altogether (any such fact being also endowed by our premise with a disvalue or negative value). Facts belonging to the first two types are value-endowed simply by the premise that selfhood is good; facts of the third type can be value-endowed only if we supply the additional premise that what ought to be ought to be allowed to be.

But in all three kinds of case, the facts in question are endowed with value only by the use of the premise "Selfhood is good"; and the valuing element enters only because it is contained in that premise. In other words, 
this kind of value endowment is not a direct extraction of values from facts, but a syllogistic operation in which we supply the value element in our major premise. The process will look like a direct extraction of values from facts only if we suppress that major premise so that we are left with an enthy. meme; ${ }^{185}$ once we articulate the suppressed premise and so disclose what is really involved, we see that the value is not found in the fact at all. Of course, this would still be a valid way of "bridging the gap" between facts and values if the premise "Selfhood is good" were an a priori judgment of the human mind, or even if though not a priori it could be justified by an unassailable process of argumentation. But any actual attempt to justify it within the framework of "authenticity" would have to rely, first, on the factual judgment that only those human beings who possess the qualities of selfhood are "genuinely" or "truly" human, or capture the "essence" of humanity - in short, that "selfhood" represents human "authenticity of fact" - and second, on the conceptual judgment that "authenticity of fact" entails "authenticity of fittingness." These two judgments in turn would then have to be justified either by an indisputable demonstration of their a priori character, or by unassailable substantive argumentation. Now, the latter judgment, that "authenticity of fact" entails "authenticity of fittingness," may indeed be reducible to a tautology and hence justifiable a priori. This is a complex and difficult question which is outside the scope of this article. But the former judgment, the existentialists' factual judgment about what constitutes human "authenticity," can obviously not be indisputably demonstrated by either a priori reasoning or otherwise. Even if we were nevertheless to accept both judgments, and assume them to be valid, where would we be?

Our premise "Selfhood is good" would then be well grounded, and by using it we would be able to endow three kinds of fact about human comportment with three corresponding kinds of value significance. But these three kinds of fact would still constitute only an extremely limited range of facts. To say that we had in a certain sense solved the fact-value problem within this limited range might perhaps encourage us to persevere in the search for a more general solution, but it would not itself constitute a general solution, nor even a stepping-stone towards this. The three kinds of value significance that we had arrived at would also be of very limited and rather unexciting range. To search for a link between facts and values within a natural law context is a significant enterprise only if the values ultimately arrived at have some sort of legal significance. But it is difficult to see what legal significance can attach to the conclusions that individuals displaying

185 Cf. Tammelo, article cited supra note 8 , at 257-258. 
the qualities of selfhood are to be valued, and that individuals lacking those qualities are to be disvalued. The conclusion that barriers to selfhood ought to be removed does have legal significance; yet its significance in no way differs from that of the Kantian ideal of "a universal law of freedom" under which "the voluntary actions of any one person can be harmonized with the voluntary actions of every other person"; ${ }^{186}$ and the net effect of its adoption into legal philosophy would be only to set us back on the treadmill of nineteenth century laissez faire. ${ }^{187}$ In part, as in the long succession of extreme "liberty of contract" cases, ${ }^{188}$ this line of thinking led nineteenth century law into conceptual excesses and obstructions to social welfare, on which we ought not lightly to reembark. In part, it stressed goals for democratic development, and restraints on legal interventionism, which are of continuing and indeed of increasing importance for all fundamental thinking about the proper role of law in a free society. But insofar as they do have continuing value, the prescriptions and the warnings which are contained in the ideal of maximization of equal liberty are already fully spelled out in philosophical and juristic writings going back to Kant, and indeed to Locke. To attempt to discover them anew on the basis of existentialist "authenticity" would be as pointless an exercise as reinventing the wheel. ${ }^{189}$

We turn, therefore, to the other extreme, that of borrowing only the bare idea of using "authenticity" as a value, and applying it quite independently of its existentialist origins. We find ourselves at one stroke endowing almost every factual proposition that can be made with value significance. What we shall then be saying is simply that any entity's "authenticity of fact" entails an "authenticity of fittingness": that to say " $\mathrm{X}$ is $\mathrm{Y}$ " will always entail "It is good for $\mathrm{X}$ to be $\mathrm{Y}$," regardless of what $\mathrm{X}$ and $\mathrm{Y}$ may be.

We are trying to see what sense can be made of "authenticity" outside an existentialist framework. Within that framework, or even within a modified version of it, the range of facts which "authenticity" could endow with value significance would still be limited to "individual-concrete" facts. The fact that "I have just saved a girl from drowning" would mean that it was right for me to have saved that girl at that moment; but within the existentialist framework there would be no way of getting from this "concrete" value judgment to the "abstract" judgment that "I ought to save people from drowning,"

186 Cf. Kant, Metaphysische Anfangsgründe der Rechtslehre xxxili (1797); and English translation by W. Hastie, Kant's Philosophy op Law 45 (1887).

187 See citations supra note 1 .

188 Adkins v. Children's Hospital, 261 U.S. 525, was decided in 1922 and overruled only in West Coast Hotels Co. v. Parrish, 300 U.S. 379 (1937). For other cases see Stone, op. cit. supra note $1,91-99$.

180 Cf. Harry Alpert, Some Observations on the State of Sociology, 6 PAcific Sociolocical Review 45 (1963). 
still less to the "abstract-general" judgment that "Men ought to save people from drowning." But once we leave the existentialist framework behind, and seek only what value judgments we can sensibly derive from facts by means of the concept of "authenticity," the exact converse applies. The only qualification that can then be made is that in order to be value-endowed a "fact" must be of sufficient generality to enable it to be construed as a continuing "expectation," or as the basis for such an expectation. ${ }^{190}$ Thus, the fact that "The chicken crossed the road" or that "This chicken has just laid an egg" will carry no value significance; but the fact that "Chickens lay eggs" will entail that it is good for chickens to lay eggs. Again, the fact that "Jacques saved a girl from drowning today" or that "Jacques will rob a bank tomorrow" will be value-free; but the fact that "Jacques is a bank robber" will entail that it is good for Jacques to rob banks.

Now, whereas we found the range of value endowments which a strictly existentialist "authenticity" could offer to be unexcitingly small, the range which "authenticity" as such offers is obviously preposterously large. On the one hand, it brings into the range of moral valuing the whole range of phenomena in the universe, including nonhuman and even inanimate entities whose "value" is at first sight of no possible legal or even moral relevance. We can, indeed, give this kind of "value" both legal and moral relevance by supplementing it with our additional premise "What ought to be, ought to be allowed to be"; but this appears to leave us worse off, rather than better. For we would then be saying that since all of physical nature is good, none of it ought to be interfered with. In other (words, we would be reinvoking what has recently been castigated as "the crudest of the false notions" of natural law: "the idea that acceptance of natural law implies an obligation never to interfere with the processes of physical nature; . . . that men are obliged to be completely subservient to the 'laws of nature,' as if . . . man was meant to be the helpless victim of his physical environment."191 $\mathrm{Ob}$ viously, no one would want to say this. On the other hand, in both the human and nonhuman spheres, the doctrine that "Whatever is, is good" would lead us to endow with positive value the most obvious evils. It would be "inauthentic," and therefore wrong, for an angora rabbit to inflict poisonous bites and to prey on smaller animals; but it would be "authentic," and

190 I have made the above qualification intuitively; on later investigation it seems to be based on the twofold assumption that any proposition which is to have practical value significance must be (i) future oriented, and (ii) capable of "universalizability" or at least of "generalizability." Both assumptions are open to question; but I believe that, once we leave the existentialist framework behind, the second, at least, may reasonably be adopted. Cf. R. M. Hare, Freedom and Reason $10 \mathrm{ff}$. (1963).

191 John Cogley, Introduction to work cited supra note 156,11 , at 17. 
therefore profoundly right, for a rattlesnake to do this. It would be "inauthentic" and wrong for a quiet, law-abiding family man suddenly to steal a million dollars; and it might even be inauthentic and wrong for a potentially decent citizen to be forced by social and environmental circumstances into a life of crime and depravity. But for the criminal by choice, every conceivable crime and depravity would be "authentic" and right. Sartre, indeed, would say exactly this; ${ }^{192}$ but few of us would want to agree. Here again, the additional premise that what ought to be should be allowed to be would make the position even worse; for by adding it we should be forced to the conclusion that rattlesnakes and tigers, volcanoes and floods, bank robbers and murderers and pederasts were not only authentically "right" in themselves but should on no account be interfered with by us.

In short, this kind of "authenticity" as a link between facts and values cannot be useful or even meaningful unless we can find some way of limiting its range of application. One way of doing this might be through the traditional Aristotelian teleology, through the notion that not everything that is, but only what is in a way that fulfils its essential nature, is "good."193 But this would merely return us to the many problems of Aristotelian natural law, no better equipped to deal with them than we were before: once again, our excursion into existentialism would have brought us out exactly where we came in. In any case, even if this were to solve the problem of human evil, it would only heighten the problem as to wild creatures and natural phenomena that are inimical to man. ${ }^{194}$ Another solution might be found by partially reintegrating the "authenticity" notion into its existentialist sources, i.e., by appealing to the existentialist merger of authenticity of fact and of fittingness with "authenticity of origin" (in the sense of "authorship"). But while this solution might solve the problem of nonhuman inimicality, it would still leave us with the problem of man's inhumanity to man. It would limit an entity's "authentic" characteristics and behavior to those of which the entity was in some sense the "author," and this would probably confine the applicability of the notion to human characteristics and behavior. But in

192 Cf. Jean-Paul Sartre, Saint Genet: Comédien et Martyr (1952); and English translation by B. Frechtman, SAINT GeNET (1963).

${ }^{193}$ See, e.g., John Wird, Plato's Modern Enemies and the Theory of Natural law (1953). And see the criticism by Hans Kelsen, $A$ "Dynamic" Theory of Natural Law, 16 Louisiana Law Review 597 (1956), reprinted in his What is Justice? 174 (1957), and more briefly restated in his Platon und die Naturrechtslehre, 8 Osterreichische Zetrschrift Für ÖfFentuighes Recht 1 (1957); and Wild's reply, Plato and Natural Law, 11 OSterReichische ZeItschrift für Öffentliches Recht 177 (1961).

104 See Kelsen, essay first cited supra note 193 , at 606 (What Is JUSTICE? 183-184). And cf. Richard V. Carpenter, The Problem of Value Judgments as Norms of Law, 7 Journal of Legal Education 163, at 164 (1954). 
the human sphere we would still have to say without exception that any action freely undertaken would be good.

A more promising approach seems to open up, however, if we are prepared to recognize "authenticity" as one value among others. The judgment that whatever is, is good will then still be valid, but it will have only (as it were) a defeasible validity: what is authentic will be good only so long as it does not conflict with other value judgments, otherwise based. One way of putting this is to say that in the end result we should recognize as "authentic" not everything that exists, but only what exists in a way that is pleasing, comfortable, or otherwise satisfying to human beings in the light of their other values. ${ }^{195}$ But I should now prefer the converse way of putting it: that we should recognize as "authentic" everything that exists, without exception, and that every existing entity has therefore a claim to noninterference; but that this claim, while not disappearing, will be outweighed as soon as an entity becomes offensive, threatening, or otherwise unacceptable to human beings in the light of their other values. This enables us to preserve the conclusion that all actual physical phenomena and all actual human activities are good, and ought not to be interfered with; but to cut this conclusion short as soon as a conflict with some other value judgment arises.

Still another way of putting it arises if we return to our premise that what ought to be should be allowed to be. To add this premise to the "authenticity" premise produces the initial result that everything that is has a claim to go undisturbed. But since all these claims cannot be satisfied, we are compelled as a practical matter to reformulate this: to say that everything that is shall go undisturbed to the maximum extent that is compatible with the similar claim of everything else that is. To a certain extent we can then get along without recourse to other values; our aim will be rather analogous to that of Pound's balancing of interests, except that instead of dealing with claims to something we shall be dealing merely with claims to be. And, of course, we shall have the whole universe and not merely the human universe for our canvas. The objective of satisfying as many claims to undisturbed being as possible, with the least friction and waste, ${ }^{196}$ will not allow us altogether to dispense with other values; for we shall still have to deal with direct clashes between competing claims to be, and in determining priorities as between the competing claims we shall have to decide which of the competing

\footnotetext{
185 See Blackshield, article cited supre note 89 , at 480.

206 I am here, of course, deliberately paralleling Pound's statement of his theory of law as the adjustment of de facto interests. See, e.g., Roscoz Pound, Soctul Control throvar Lnw 65 (1942). And cf. Roscoz Pound, 3 Jurisprudence 16 (1959).
} 
entities is more valuable to us. We can hardly say that everything "ought to be," but some things "ought to be" more than others: we shall have to appeal to overriding values, for instance that of human security. Even here we will still get some guidance from the overall demand that as far as possible we should not interfere with any authentic entity, nor with any authentic human behavior.

Whether we speak in terms of a plurality of values, amongst which "authenticity" has only a defeasible claim to validity, or in terms of a competition of "authentic" claims to be, which we must balance as best we can, it is thus possible to bring the value of authenticity within meaningful and manageable bounds. That value, with its attendant demand that every entity should be allowed to be, can then still be used (for example) to support condemnations of the wanton destruction of animals and trees, and indeed to support demands for their conservation, without committing us at the same time to the conservation of snakes and beasts of prey, or to passive submission to fire and flood. We will not be prevented by the "authenticity" concept from interfering with any existing entities or behavior; but in any such interference the onus will rest with us of justifying what we are doing, of showing that interference is warranted. Killing a rattlesnake will be permissible, but killing an angora rabbit will be wrong. Legal action against criminals will be permissible, but legal action against private immorality which does no harm to anyone other than the participants will be wrong. While these and most of the other ethical judgments we shall be led to are only those which most of us would in any case make without an appeal to "authenticity," at least some of these judgments will be more substantially grounded, and more clearly marked out as "ethical," by the appeal to this concept than by anything contained in our existing apparatus of ethical theory. By supplementing the "authenticity" notion with an appeal to other values, we convert it from an absurdity into an acceptable, meaningful, and even valuable contribution to our overall ethical thinking.

Yet, of course, at the same time, the recourse to other values greatly restricts the importance of the "authenticity" notion as a link between facts and values. On the above analysis these other values will be the ultimately crucial determinants of most of our ethical problems; and these other values are not rooted in "authenticity," but are additional to and distinct from anything that that concept can yield. Thus, although the range of facts which authenticity endows with values is (as we have seen) almost unlimited, the range of values which authenticity roots in facts is very limited and unimportant indeed. Finally, then, whatever contribution it might make to overall 
ethical theorizing, the "authenticity" notion as a solution to the fact-value problem fails to live up to its initial promise.

There is one other path by which existentialism, or at least its German variety, might help us to solve the problem of facts and values. This is a more shadowy path, which can only be hinted at; on the other hand, while the "laws" it produces will (as we shall see) be only "cipher" laws and only "individual" laws, they will, I believe, escape the restriction that they can be only "concrete" laws. Indeed, in Bobbio's terminology they will be highly "abstract" principles.

The best of traditional natural law thinking has always searched for "higher law" only in the sense of a handful of abstract and very general principles. The idea of a "higher law" in this sense seems at least to be consistent with the "higher realms of Being" ("Being-itself," the "Transcendent," the "Encompassing") of German existentialism; indeed, Jaspers' unutterable vision of "the Encompassing" seems hardly to make sense unless we can interpret it as including such general principles. One such general principle, for instance, would be what Jaspers calls the "unconditional imperative," which seems to boil down to the principle "Live out of love."197 Some such principle as this must surely be basic to any worthwhile natural law theory.

Further, the traditional natural law idea that natural phenomena can help us to apprehend such "higher law" principles seems to be equally consistent with Jaspers' view of worldly phenomena as "ciphers" of the Transcendent. On this view, we can discover the principles of the Encompassing by confronting worldly phenomena in a transcendent cipher reading which rises above their worldliness and enables us to glimpse the Encompassing itself. Its principles can then become our principles, as a result of a decision which each of us makes when receptively confronted with the Encompassing.

This final path to the understanding of facts and values does not, of course, offer a solution to the fact-value problem. But it does offer a new statement of what it is that those who strive to ground values in facts are really yearning for. It is thus at least of clarifying value. Moreover, at least one thing that it clarifies is of great importance for all natural law theorizing. This is that such principles, however profoundly we may plumb the depths of Being in our attempt to find them, can never be absolutely found by man. The most we can do is to formulate for ourselves ciphers of the absolute principles of the Encompassing: those principles themselves must remain forever hidden. ${ }^{198}$ The world of Existenz simply is not a world of absolutes; "be-

197 Einführung in die Philosophie 50-60, esp. 59 (Way to Wisdom 52-62, esp. 62). $198 \mathrm{Cf}$. my article cited supra note 89 at $510 \mathrm{ff}$. 
tween man and the truth lies dying," wrote Kierkegaard. ${ }^{199}$ When we reach for absolute moral principles in this world, we reach into inauthenticity. In this sense Jaspers, for instance, would say that the striving for absoluteness leads us yet again into "guilt," and for this guilt Existenz "must do penance and suffer shipwreck. It is shipwrecked because it aspires to things infinite."200 Yet, even while the (impossible) achievement of the goal would be inauthentic, the striving for it is profoundly authentic for man. The search for natural law (as distinct from any particular natural law contents that may be offered) is thus well attuned to existentialism.

Yet it may more nearly avoid the "guilt of absoluteness," and thus be even better attuned, if we approach the quest for ethical guides for law in terms of a search for "justice," abandoning altogether the language and the concepts of "natural law." The search for "justice" does not carry the misleading implication that what we are looking for is to be found in the form of "laws."201 What, then, can existentialism tell us about an inquiry into the value of "justice"?

Its first lesson goes to the axiological character and status of all values. This is that "values" in general have no reality except in our acts of evaluation, in the way we look at the world and each other, in the "pro-jects" we map out for ourselves and the goals we set for ourselves. In other words, the extreme subjectivism of Kierkegaard's attitude to "truth" is repeated in the existentialist attitude to "values." But here, I believe, the fundamental source of subjectivism is not Kierkegaard, but Nietzsche, who proclaimed that

It is we, who think and feel, that actually and unceasingly make something which did not before exist: the whole eternally increasing world of valuations, colors, weights, perspectives, gradations, affirmations and negations. ... Whatever has value in the present world, has not it in itself, by its nature - nature is always worthless - but a value was once given to it, bestowed upon it and it was we who gave and bestowed! We only have created the world which is of any account to man! ${ }^{202}$ :

This "absolute relativism" pervades all modern existentialism; but only in Sartre does it reassume its full Nietzschean proportions. ${ }^{203}$ Sartre stresses the point again and again, making it almost the central theme of his whole

\footnotetext{
199 Journals, II, 197.

2003 Philosopuie 227 ff. (edition cited supra note 69). Cf. infra note 211.

201 See Stone, op. cit. supra note 1 , at 32, 290, 295-296.

202 Friedrich Nietzsche, The Joyful Wisdom, IV, 301 ; in 6 Nietzsches Werke 257 (1906), and English translation by T. Common, in 10 Complete, Works op Friedrich Nretzsche 235-236 (1910) (editions cited supra note 38).

203 Cf. Molins, op. cit. supra note 20 , at $80-81$, 97-99.
} 
philosophy. There are no objective values: I create values in my act of valuing, and they are values only for me. "There is no general morality," and accordingly "no general morality can tell me what is to be done."204 In every situation I confront that calls for a value judgment, I must supply both the value and the judgment, out of my own being. But there is nothing in my own being - nothing but absolute freedom. Hence I must face the gaping fact that my value judgments are "pro-jected" out of an abyss, that value

can be revealed only to an active freedom which makes it exist as value by the sole fact of recognizing it as such . . . that my freedom is the unique foundation of values and that nothing, absolutely nothing, justifies me in adopting this or that particular value, this or that particular scale of values. 205

Even if I do adopt my values from sources outside my present situation from parents or teachers or the Church, or from the results of my own previous reflections, or from the advice of friends - it is still only my decision now to adopt them and act upon them that makes them values for me.

Like most value-relativism, ${ }^{206}$ the Sartrian brand carries with it an emphasis on personal responsibility. If every value judgment I make is my choice, then I am responsible for my choice.

I do not have nor can I have recourse to any value against the fact that it is I who sustain values in being. Nothing can ensure me against myself, cut off from the world and from my essence by this nothingness which I am. . . I I make my decision ... without justification and without excuse. 207

Even if I choose not to choose, I choose all the same. ${ }^{208}$

The idea of personal responsibility may seem perilously little to rescue from the general shipwreck of values that such a position appears to involve. Yet the existentialist is not really denying the crucial importance of value judgments in human existence; he is only denying that these value judgments can be objectively based. He is saying that to refer to the controlling core of such judgments by the grammatical substantive "value," is to use

\footnotetext{
204 L'Exustentialisme est Un Humanisme 47 (Kaupmann, op. cit. supra note 20, at 297). On the twist in the original Kierkegaardian impetus which this aspect of Sartre's thinking involves, see Colrins, op. cit. supra note 35 , at $66 \mathrm{ff}$.

${ }^{205}$ L'Etre et le Néant 76 (Brino and Nothinoness 39).

206 Cf. Stone, op. cit. supra note 1, at $231 \mathrm{ff}$., 237, 239, $258 \mathrm{ff}$.

${ }^{207}$ L'Etre et le Néant 77 (Beino and Nothingness 39).

208 L'Exastentialisme est UN Humanisme 73 (KaupmanN, op. cit. supta note 20, at 305).
} 
a misleading expression: what really governs can only be referred to by the verb "to value." $\mathrm{He}$ is not annihilating our values; but he is telling us that they are only our values. He is not denying justice; but he is saying that "justice" for me in any situation in which I am called upon to render it, is what I choose as "just" in that situation. He is not urging me to abandon my attempts at value judgment, but to strive more conscientiously to make only value judgments that I believe to be right. For this, finally, is what "making a value judgment" really means: a "judgment" which unquestioningly applies secondhand precepts involves no element of valuing at all.

Is it possible, on such a basis, to say anything about "justice" at all? I believe it is; but we must be careful what we are saying. First, it may still be possible to give a partial meaning to justice by surveying the kinds of situation in which men think of their choices in terms of the value of "justice," and saying that "justice" is, at any rate, a value that pertains to that kind of situation. If $I$ thereafter find myself in such a situation, it will be entirely proper for me to think of my problem as one of deciding what justice requires. But my decision will still be something that I must choose, and by choosing it $I$ will create "my" justice of that situation. Secondly, it may even be possible for me to survey the kinds of value judgment that men actually make in such situations, and to extract from this survey a generalization about what the content of justice for men generally has been; or it may be possible for me to conduct a similar survey of the kinds of value judgment that I habitually make in response to what I conceive of as questions of justice, and to extract a generalization about what the content of "justice" is for me. In neither case will the resulting generalization be meaningless. But in neither case can it serve as a prescription which I can simply apply in any justice problem that I now face, still less as one which I can impose on any other human being who is faced with a problem of justice. It is in the very nature of "justice" as a value that all such generalizations which I may bring to a specific justice problem, and all "theories" or "doctrines" of justice, or examples of "just" conduct in other situations, can at most present me with possibilities amongst which I must choose. For "valuing" is choosing, and choosing in the here and now.

Thirdly, if valuing is choosing, it follows that valuing is only possible if there are possibilities to choose from. Even if a problem situation is the kind of situation to which the "value" of justice pertains, a solution can only be a "just" solution (or a "valuing" solution at all) if there is a choice available among possible solutions. If only one possible course of action is open to us, then there is no ethical problem at all; and it would be meaningless to talk of "values" in a situation which presents no ethical problem. Again, 
if no possibilities are available at all, then "justice" cannot be done in that situation.

For Sartre, this kind of situation would itself not be a real possibility. For him, there is always a plurality of possibilities, so that every situation is an ethical situation, and in every situation the freedom of human choice is unlimited. But for Jaspers, as we have seen, freedom is not unlimited: there are "limit-situations" before which human potentialities come to a full stop. 209 $\mathrm{He}$ adds expressly ${ }^{210}$ that one of these is irremediable injustice; there are "situations which cannot be solved by justice, the situations arising for example from the increase and redistribution of the population or from the exclusive possession by one group of something which all desire and which cannot be divided."

All this may contain a certain number of wise insights for judges and legislators; but such insights do not, of course, amount to a theory of justice. If we accept the insights we cannot even ask for a "theory of justice" in the sense of a set of substantive directives which we need only to apply to any "justice problem" to produce the "just" solution. Finding the just solution will be precisely our problem. On the other hand, unless a body of philosophy can give us some guidance in our approach to this core problem of justice, it cannot be said to be of any practical use for this aspect of law and legal philosophy at all. Either we must conclude that existentialism has nothing to say about this aspect of legal philosophical concern, or we must find some substantive guidance towards a "just" solution in what it does have to say. Furthermore, this must be guidance that is acceptable within a legal philosophical framework.

If any such guidance is to be found in existentialism, it must be found secreted within the simple proposition that the "just" solution which I must find for any problem must be constituted by $m y$ response to that particular problem situation. This does, I believe, offer guidance on two points. First, it tells me that what I am looking for as the "just" solution to a problem situation is an individual-concrete norm of that unique situation. To apply a norm derived from some other situation will not be "just" unless I decide that the norm is "right" for the present situation. Secondly, it tells me that justice must be based on an understanding of the situation to which the "just" solution must be applied. I cannot possibly shape my decision in a

\footnotetext{
209 PhILosophie 469 (edition cited supra note 102). And cf. Gabriel Marcel, Situation Fondamentale et Situation-Limite chez Karl Jaspers, in Gabriel Marcel, Du Refus A L'INVOCATION (1948).

210 Einführuno in die Philosophie 103 (Way to Wisdom 108). Cf. Philosophie 347 (edition cited supra note 102).
} 
way appropriate to a situation unless I know what the situation is. Both these directives do offer some substantive guidance to my search for a "just" solution. It is only a preliminary and indeterminate sort of guidance, which still leaves to my choice the really hard job of decision; but on the existentialist premises this is the most that we can expect. The question is, can either of these directives be regarded as acceptable within a legal-philosophical framework? In other words, is either of them consistent with what any legalphilosophical viewpoint must recognize as the inescapable practicalities and feasibilities and very "nature" of law?211

211 A third possible directive seems to go quite beyond what is legally feasible and practical, and $I$ have therefore not considered it in the text. This is that the search for justice should be seen as a striving, in which the person trying to do justice struggles to transcend his situation and himself. Even this might have some value, as giving our search for justice a certain orientation (though in no way a specific orientation) towards what Lon Fuller calls "the morality of aspiration." See Fuller, op. cit. supra note 6 , at $5 \mathrm{ff}$. On the basis of Jaspers' philosophy, certainly, we should have to say that "justice" in an absolute, final, perfect sense can never be achieved; but that what is possible, and also necessary, is that we should strive for such a perfect justice. If our efforts still end (by that perfect standard) in defeat, then at least this is an authentic human defeat - the "shipwreck" which is not shameful, but man's final dignity. Cf. the concluding sentence of Jaspers' PrrLosopHre; and cf. on "shipwreck" infra note 219.

More specifically, such a directive might be offered within an existentialist framework as the solution both of the problem just considered of irremediable injustice, and of the problem presently to be dealt with of the conflict between generalized and individualized justice. As to irremediable injustice, the implications of such a directive might vary according to the degree of injustice involved. In the case of mere petty, annoying, and unimportant injustices, we might be told simply not to let our thought be dragged down to their trivial level - though this has a rather unpalatable inhumanity about it if we take the view that all injustices are important. At any rate as to all injustices which are of any importance, and certainly as to the major human problems that Jaspers has in mind when he speaks of irremediable injustice as a "limit-situation," we would be told rather that the whole unjust situation is something to be overcome, not merely by the vain attempt to do justice within the situation, but by a radical remaking of the situation. Finally, as to the conflict between generalized and individualized justice, the same directive would tell us that this whole antinomy was something to be overcome; that we should strive for a solution which would be "more" than either side of the antinomy could offer. But what precisely this could mean still seems doubtful.

In all this, as in the general existentialist rethinking of the axiological status of values, the starting point would have to be found in the iconoclasms of Nietzsche, notably in a striking passage from sec. 6 of the preface to Human AlL-Too-Human (1878): in 3 Nietzscers WeRke 11-12 (1906), and English translation (which I here only partly follow) by H. Zimmern, in 6 Complete Works of Friedrich Nietzsche 9-10 (1909) (editions cited supra note 38 ). The passage is quoted in part, with a valuable discussion of its jurisprudential implications, in Boasson, article cited supra note 21 , at 469 , but needs to be quoted here at greater length:

Thou shouldst obtain "power over thy pro and contra, and learn how to put them forth and withdraw them in accordance with thy higher purpose. Thou shouldst learn how to take the proper perspective of every valuation - the shifting, distortion, and apparent teleology of the horizons and everything that belongs to perspective; also the amount of stupidity which opposite values involve, and all the intellectual loss with which every pro and contra has to be paid for. Thou shouldst learn how much necessary injustice there is in every for and against, injustice as inseparable from life, and life itself as conditioned by the perspective and its injustice. Above all thou shouldst see clearly where the injustice is always greatest: - namely, where life has developed most punily, restrictedly, necessitously, and incipiently, and yet cannot 
In relation to the former, "individualist" directive, this question brings us face to face with the age-old legal-philosophical conflict between "justice" as a demand for fair and appropriate treatment of individuals, and "justice" as a demand for impartial and regular treatment as between individuals. It is the conflict which has recently been graphically stated by Lon Fuller in relation to our use of such notions as "the reasonable man" in law. If we apply this notion to a particular defendant as an objective standard, says Fuller,

we obviously run the risk of imposing on him requirements he is incapable of meeting, for his education and native capacities may not bring this standard within his reach. If we take the opposite course and attempt to ask whether the man before us, with all his individual limitations and quirks, fell short of what he ought to have achieved, we enter upon a hazardous inquiry in which all capacity for objective judgment may be lost. This inquiry requires a sympathetic identification with the life of. another. Obviously differences of class, race, religion, age, and culture may obstruct and distort that identification. The result is that though an aloof justice is bound at times to be harsh, an intimate justice, seeking to explore and grasp the boundaries of a private world, cannot in the nature of things be evenhanded. The law knows no magic that will enable it to transcend this antinomy. ${ }^{212}$

The troublesomeness of this conflict for the whole endeavor to apply existentialism to law was foreshadowed at the very outset. It underlies the tension between individual and society and that between existentialism's individual-concrete orientation and the idea of natural law. Perhaps some such conflict even underlies the paradoxical relation between "authenticity" as a denial of all generalized "essences," and "authenticity" as itself a kind of "essence," which is central to that whole concept. Now at last we are squarely face to face with the underlying conflict itself: between the existentialist implication that justice must be found subjectively in relation to each individual, and the legal implication that justice must be found objectively from one individual to another.

As lawyers, we will inevitably tend to favor the legal side of this dilemma. Of course, we will say, the law would be more just if it could always be shaped to the individual's subjectivity; but to try to build a system of law on this basis would be both an impossible burden for judges and a departure from other requirements of justice. It would be just to the individual

help . . . secretly, basely, and continuously eroding and calling in question the higher, greater, and richer - thou shouldst see clearly the problem of gradation of rank, and how power and law and amplitude of perspective grow up together.

212. Fulled, op. cit. supra note 6, at 71-72. 
in the individual case, but unjust as between individuals from one case to another. Should we, and in any case can we, allow existentialism to wean us away from this invariable assumption of lawyers? Can existentialism offer an alternative solution of the conflict which would have even prima facie feasibility?

All that we can do here is to try to imagine what an existentialist account of this perennial conflict would be like. There are two distinct aspects of the problem which such an account would have to deal with: first, the practical demand for objectivity as against the existentialists' demand for subjectivity; and second, the "just" demand for regularity as against the existentialists' demand for individuality. On the first score, the existentialists would have to deny all value to the lawyers' "objective" view: here there could be no solution, but simply a clash of demands. Insofar as the lawyers' demand was grounded solely on feasibility, the existentialists might offer a solution of sorts if they could show that their demand was also feasible; this would throw them back on their demand for an understanding of the situation, which we shall come to in a moment. On the second score, however, the existentialists would not deny all significance to the lawyers' point of view. First, they would readily concede that any individual confronted with a problem of justice - that is, finding himself in a situation in which he feels called upon to do justice, to act as what I shall call a "justicier" - might naturally want to survey his own and other justiciers' past solutions to more or less similar problems, and his projections of what he might regard as just in other more or less similar problems which were foreseeable or imaginable; this survey would be nothing more than a device for bringing more exhaustively before his mind the range of possibilities from which he must now choose. Second, they might also concede that in addressing his mind to this range of possibilities, any individual justicier might be influenced by a kind of preliminary value judgment which he might choose to make, to the effect that consistency between his immediate decision and those other past or possible decisions ought to be one of the values that his present decision should aim at satisfying. The degree of compulsiveness in the instant situation which those other decisions would have (ranging all the way from mere possibility to absolute governance) would depend upon the degree of compulsiveness which the particular justicier put into this preliminary value judgment as he related it to the instant problem. To make this preliminary value judgment need not necessarily involve an importing into the instant situation of illusory external determinants; it might involve merely a response to a certain aspect of the instant situation, namely, that it occurs within the wider context of a continuing stream of situations with which the particular justicier must cope. 
This wider context will always be present as one aspect, or one "dimension," of every situation. But the questions of how much importance this dimension will have in the overall picture of any particular situation, and hence of the degree of compulsiveness for any particular justicier of the preliminary value judgment as to consistency, and for that matter the question whether this preliminary value judgment presents itself to him as needing to be made at all, will all depend on a number of factors. In part, they will depend on how perceptive and thoughtful the particular justicier is, on how aware he is of the wider context. In part, they will depend on how singular the particular situation is. If we fancy paradox (or is it merely paradaxis?) ${ }^{213}$ we can say that all situations are unique; in any case, we can say that a particular situation may be unique in the experience of one justicier, and an everyday occurrence for another. Finally, they will depend on the relation of the particular justicier to the particular situation, as this relation presents itself to him.

At this point we need to speak with great care. Werner Maihofer, in his elaborate and ostensibly "existentialist" studies of "the nature of things," has formulated a doctrine according to which we see our ethical problem situations in terms of our "roles" in those situations, these "roles" constituting our modes of relating ourselves to our situations, our modes of being in our situations. Such a mode of being Maihofer designates as my Alssein, my "as being." $\mathrm{He}$ is then able to argue that any question in the form "What should I do?" can always be answered if put in the form "What should I do as being an attorney asked to advise on such and such a problem?" (or "as being" whatever I am). ${ }^{214}$ If we were to apply this doctrine, we could say simply that any justicier's view of his relation to any instant justice problem would be determined by his "as being": by whether he found himself confronted by a justice problem as a used-car dealer, as a victim of petty larceny, as a shipper of spoiled merchandise, as a juror or judge in a criminal trial, as an appellate common law judge, as a constitutional judge, as a legislator, and so on. This would have a good deal of plausibility: obviously, a private citizen suddenly confronted in the midst of his everyday affairs with a justice problem will be much more aware of the uniqueness of his problem, and correspondingly much less concerned to relate it to other problems, than a judge will be.

As I understand existentialism, however, it is simply not possible, if one seeks a consistent existentialist approach, to allow a particular justicier's "role"

213 A paradactical utterance is one which achieves expressiveness by infringing accepted rules of grammar and syntax. See Tammelo, article cited supra note 16, at 184n.

214 Maihofer, Vom Sinn menschlicher Ordnuno $53 \mathrm{ff}$. (1956). 
to determine his value judgments: To the extent that Maihofer does allow "roles" to govern value decision, his doctrine becomes inconsistent with his existentialist bases, however consistent it may be with the modern social sciences. 215 The most that a justicier's "role" can do is to present him with a possible set of guidelines for his decision, to remind him of what may be expected of him in relation to that decision. Whether he is content to do what is expected of him, or whether he should try to transcend what is expected of him, or whether indeed he should decide that in all conscience he must simply fly in the face of what is expected, are questions that he must decide as part of his response to each particular justice problem. Even if he does decide merely to abide by the requirements of his "role," he is responsible for that decision: he cannot transfer his responsibility to his "role." All this applies not only to the judgment of justice itself, but to the preliminary value judgment that may be involved as to whether and how far he should strive for consistency and regularity as between the instant decision and others.

On the basis of all this, the conflict between individuality and regularity emerges simply as one aspect of every problem situation, in which every individual justicier must find his own decision. No "role," not even an officially legal "role," can determine the conflict for him. A private citizen confronting a problem of justice will probably not be greatly concerned in fact with regularity and consistency between his instant decision and others. But he may well choose to approach his problem by trying to find a decision which he feels that he could fairly apply in similar cases if they arose, or by trying to find out what people generally do in such situations, and then deciding whether the solution thus suggested is one that he is prepared to act upon in this situation. On the other hand, a judge administering a legal system will probably in fact be concerned to keep his decision consistent with what other judges have done in similar cases. But the question whether the solution which those other cases suggest is one that he is prepared to act on in the case now before him will remain a question that he must answer in relation to the facts of that instant case. He can always decide (and often will) that the special circumstances of the case at bar are such that he must here depart from the general line of decision. He must always recognize this personal responsibility - accept it as his task, face it as his challenge, and zealously insist upon it as his duty and right. ${ }^{215 a}$ Of course, he

215 For fuller development of both these points, and on the difficulties and inconsistencies of the concept of Alssein generally, see Stone, article cited supra note 8.

215a This, too, is something that judges are often found to do, for instance in denying that the Fourteenth Amendment guarantee of "equal protection of the law" requires uniformity of judicial decision. See, e.g., Milwaukee Electric Ry. v. Wisconsin, 252 U.S. 100 (1920); Lavasek v. White, 339 F.2d 861 (1965). 
may decide that in the light of overall justice, or in the light of what he as a judge "must" do, he must follow the general line of decision even though it yields an unjust result in the framework of the instant case. But in that event he will still be making his value judgment about overall justice or about what judges must do. Whatever his final decision, and whatever the values he bases it on, it will be his decision, based on his values, projected into his immediate justice problem.

In the conflict between individuality and regularity of justice, then, existentialism will not offer any solution. But neither, after all, will it merely align itself intransigently on the "individuality" side of the conflict. The "individuality" which it will intransigently insist on is not that of the decision, but that of the decider; and the conflict between individuality and regularity of decision will be simply one more dilemma to be absorbed into the framework of each particular justice problem as it confronts each particular justicier. He may choose individuality or regularity, as he will; the only thing he may not do is simply to assume that the regularly arrived at decision is the "right" decision for the case before him. A decision which rejects the claims of individuality in favor of those of regularity will not necessarily be "inauthentic"; but it will be "authentic" only if it is chosen with full awareness of - and responsibility for - its impact on the subjective uniqueness of the individual case.

This requirement refers us back to the second of the guidelines suggested above for "existential justice." This is that justice must not only be a unique reaction to a unique situation; it must be based on understanding of that situation. Whenever I find myself called upon to render justice, I must first form a fully subjective understanding of the situation in which I must act. In particular, I will need to understand, fully and sympathetically, any individual in the situation who is likely to be affected by my act. This requires a "communication" with him in Jaspers' existential sense: Jaspers indeed explicitly links the need for communication with the desire for justice. For "only if there were states in which every citizen stood to every other in rela. tion of absolute solidarity could justice and freedom be secure."216

Yet this vision of justice as fundamentally dependent on communication between Existenz and Existenz makes the whole idea of justice hopelessly inconsistent with human relations d la Sartre. It is precisely in dealing with men in relation to each other that Sartrian existentialism is most appalling. In Sartre's universe the confrontation of my self with an Other is not an occasion for communication, but an occasion for fear and shame, as my

210 Einfürruno in die Philosophie 22 (Way to Wisdox 21). And cf. a main theme of Hoмmes, op. cit. supra note 13, esp. at $55 \mathrm{ff}$. 
subjective, self-conscious être-pour-soi wavers and falters before his objectivizing glance. ${ }^{217}$ Either I see the Other subjectively, but hence as a potential objectivization of my self; or I see him only objectively, as a thing. For his part he senses that I am going to objectivize him, and this fills him with fear and shame. Simultaneously, it fills him with a sort of perverse pride, and with a desire to defend himself against this threat of being reduced to the level of a thing. The only way he can do this is to get in first, and objectivize me before I can objectivize him. The result is that we no longer even try to communicate with each other, but only to objectivize each other. ${ }^{218}$ Each of us is hopelessly alone, fighting his own battle, unable ever really to communicate with another human being. We experience "communication" only in mutual inauthenticity. Our relationships with others are either of this inauthentic and therefore terrifying kind, or they are subject-object relations in the most brutal sense, in which each tries to possess the other and possess him as a thing in order to avoid the same fate. In relationships with others, I lose all that I have: my aloneness. Since others cannot communicate with me, understand me, or see me ("the real me"), they see only a picture of me; and I must struggle with every weapon at my command to avoid being cut to the pattern of this picture. I cling to my personal identity and freedom obstinately, defiantly - and in fear and shame and pride.

It may be true that all of us have actually had some experience of this mingled fear and shame and pride under the gaze of another. But surely it is not true that this experience is universal, or that we react to it in the manner Sartre describes. Each of us, surely, has also had feelings which are quite inconsistent with Sartre's dog-eat-dog world; and among these feelings (I believe) we can all find feelings of justice, and of communicative sharing with others. Even to say in Sartre's own terms that the Other "senses" that I will objectivize him must imply some degree of communication between us; and if this rudimentary communication is possible, why is it not possible to go on to the fuller communication which is necessary for justice?

Even, of course, if we do not adopt Sartre's despairing view of human relations, we may still feel that in the practical world it is impossible to achieve the depth and breadth and intimacy of Jaspers' idealized state of "communication" - at least in any legal contexts in which problems of justice arise. But at least we can try. Jaspers' philosophy, haunted though it

217 Cf. Sartre's well-known pages on the notion of "le regard" as a philosophical concept: L'ETre ET le NéANt 310-364, esp. at 323-352 (Beino and Nothingness 252-302, esp. at 264-291). And see Grene, op. cit. supra note 30, at 81-82; Desan, op. cit. supra note 74, at $66-67,70-71$.

218 L'Etre et le Néant 428-431 (Beino and Nothinoness 361-364). Gf. Grene, op. cit. supra note 30, at 78-81; Trluich, Love, Power AND Justice 42. 
is by "shipwreck" 219 and by dread, offers an optimism, an idealism, and a challenge to aspiration which the more astringent confrontations of Sartre, however intended, cannot parallel. That, finally, is why in this inventory of the resources of existentialism I have turned more often to Jaspers than to Sartre.220 Sartre is the philosopher of despair, shame, nausea, and the "Dirty Beasts"; Jaspers is the philosopher "of openness, of readiness, of restless movement, of humility, and of compassion."221 The latter is a list of qualities that lawyers and legal philosophers need even more than other men to imbibe and reimbibe. If they can get support for them from existentialism, then this alone will make a resort to that philosophy worthwhile. Insofar as we have these qualities, we may not espouse existentialism, but we will not turn our back on it either. Even while we note its oddities and inconsistencies, we will continue to search it for concepts and insights that can help us.

\footnotetext{
210 See VoN DBR WArrerrs passim, esp. at 521, $871 \mathrm{ff}$., 893 . Jaspers repeatedly warns that at any moment in my struggle to communicate, to understand, to transcend myself, I may meet with irredeemable failure. The meaning of the "limit-situations," indeed, is that ultimately all our efforts must end in such failure. This failure is what is vividly described as "shipwreck" (Scheitern). Wilde, Kluback, and Kimmel (TruTH AND SYMBoL, Introduction, 11) list the following kinds of "shipwreck" which inevitably accompany the search for knowledge if it remains on the empirical level: skepticism or the despair of the possibility of knowing; ethical impotence; loss of meaning and value; multiple forms of demonic distortion such as superstition, tyranny, and anarchy; and various forms of nihilism. And see generally Thyssen's essay cited supra note 72, esp. at $312 \mathrm{ff}$.

280 I am tempted to go so far as to say that Sartrianism is an "inauthentic mode of being" of existentialism. Cf. Marrsan, 1964 work cited supra note 19, paraphrasing Benjamin Fondane (Le Lundi Existential et le Dimanche de l'Histoire, in the symposium L'Existence, at 25-53 [1945]), to describe Sartre's philosophy as "an abortive hybrid of academic rationalism and truly existential thought." Perhaps it is paradoxically a nice indication of this "inauthenticity" that Sartre is the only one of our present "triumvirate" who allows himself to be pinned down and labelled as an "existentialist" at all. See supra note 16.

zin $\mathrm{K}$. W. Deutsch, Introduction to Tragedy is Not Enovgr 13. Cf. Jaspers' own formulation, id. at 103 (VON DER WABRHEIT 960).
} 